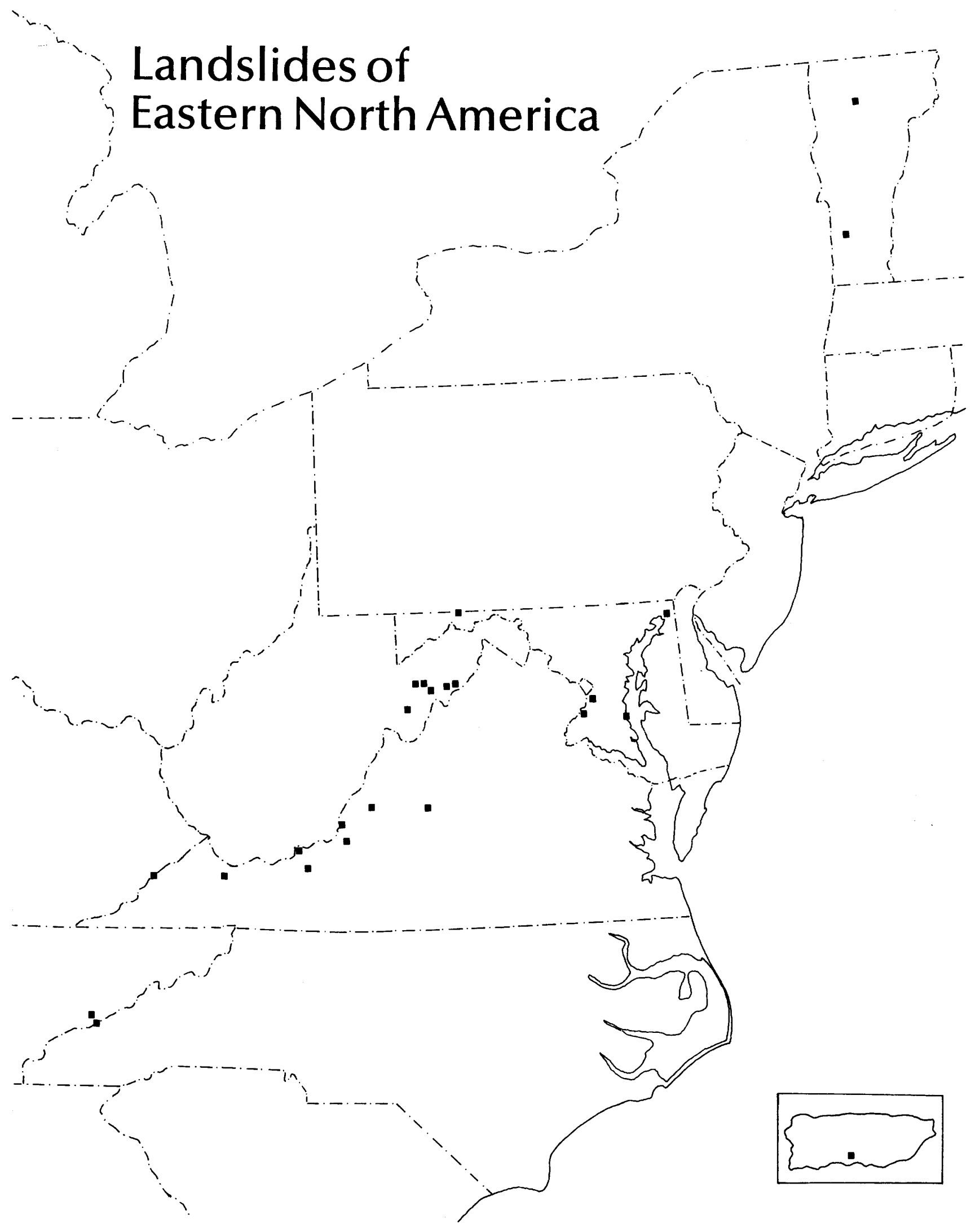

U.S. GEOLOGICAL SURVEY CIRCULAR 1008 
Index map of site-specific landslides ( $\square$ ) of Eastern North America and generalized boundaries of physiographic provinces discussed in this Circular. Numbers adjacent to landslide locales refer to the papers discussing these landslides; numbers beneath province names refer to the papers discussing landslides in these provinces.

OPPOSITE: Landsat multispectral scanner (MSS) band $5(0.6-0.7 \mu \mathrm{m})$ image mosaic of the Eastern United States compiled in 1974 by the U.S. Department of Agriculture Soil Conservation Service.

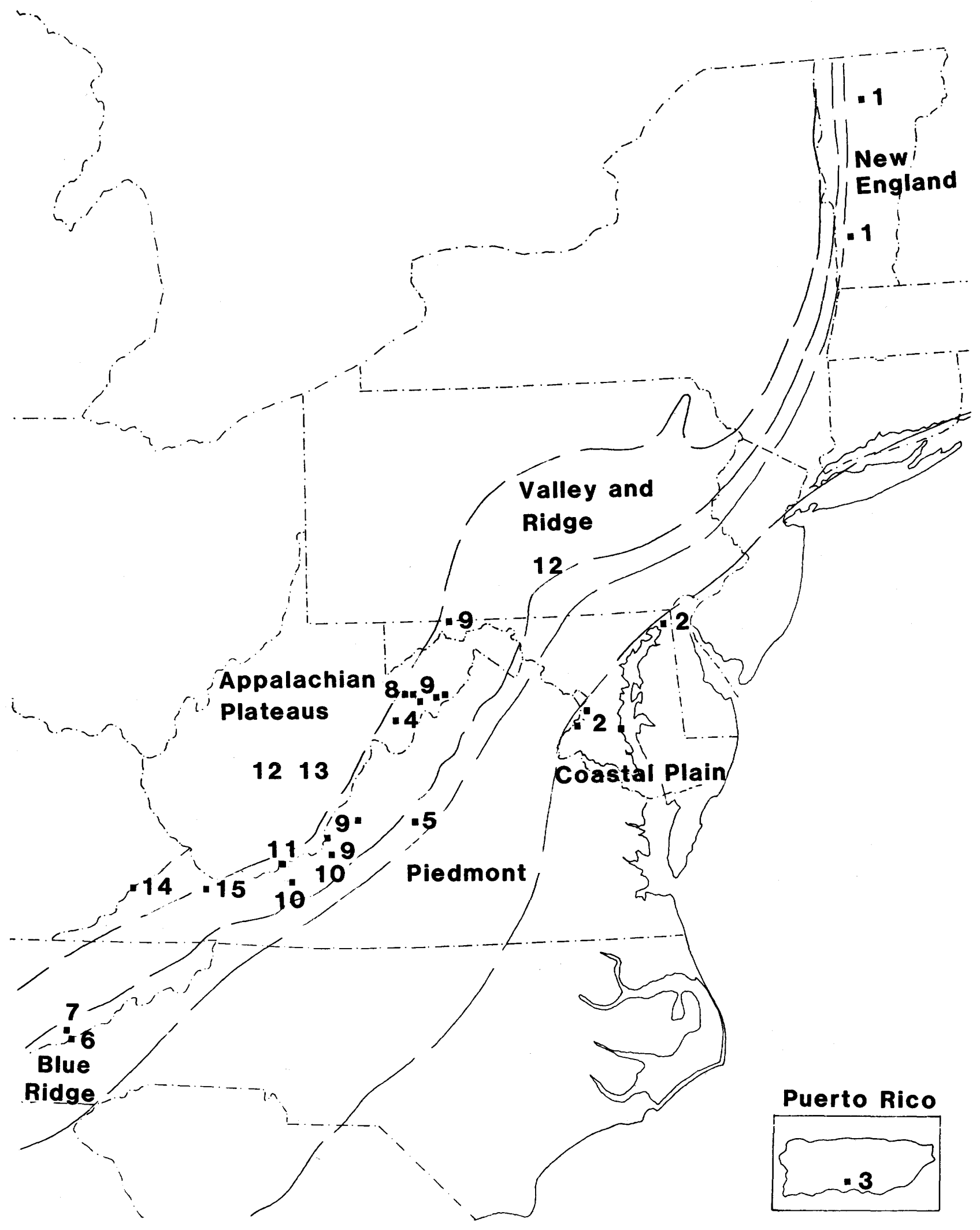




\section{Landslides of Eastern North America}

\section{ARTHUR P. SCHULTZ and C. SCOTT SOUTHWORTH, editors}

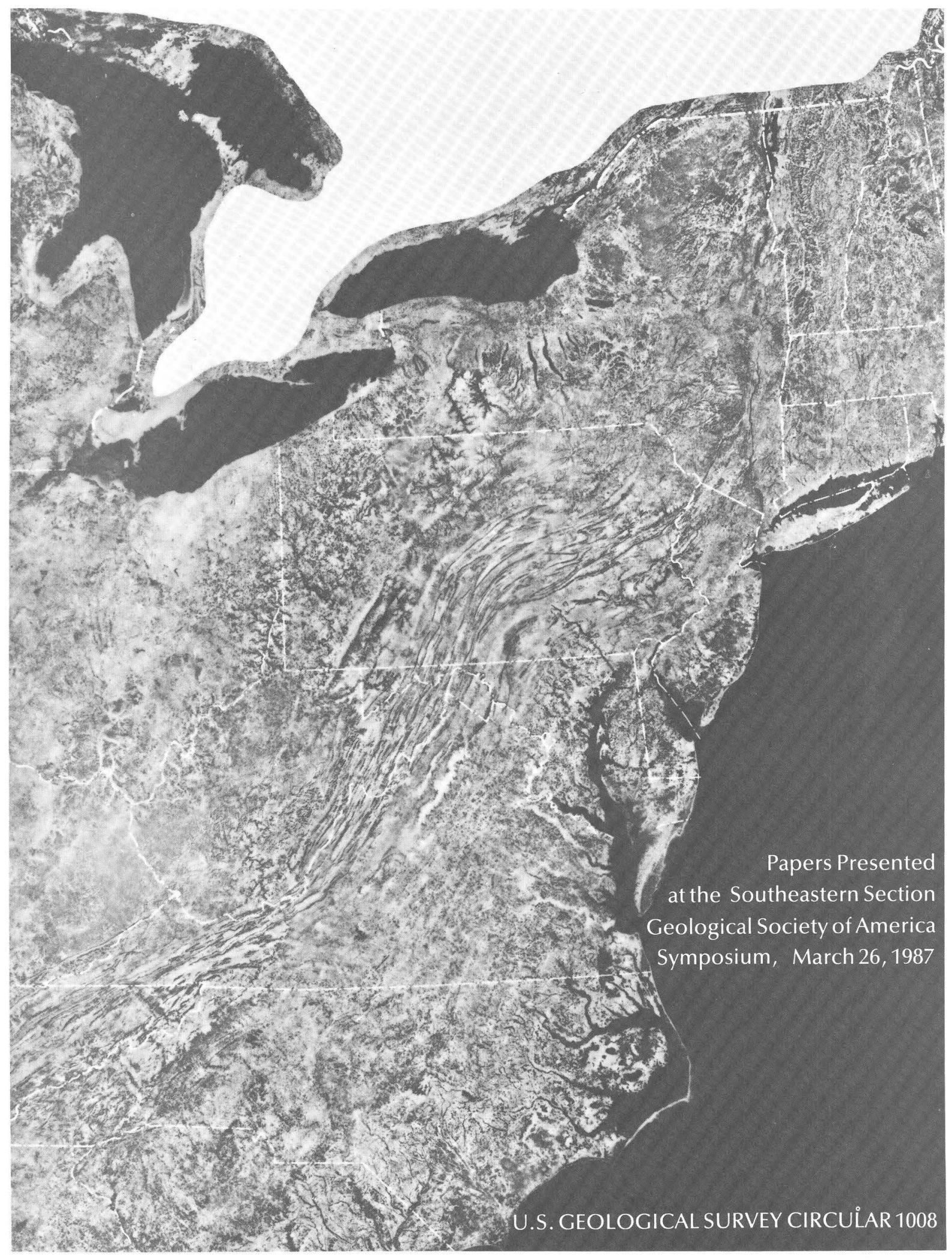


DEPARTMENT OF THE INTERIOR

DONALD PAUL HODEL, Secretary

U.S. GEOLOGICAL SURVEY

Dallas L. Peck, Director

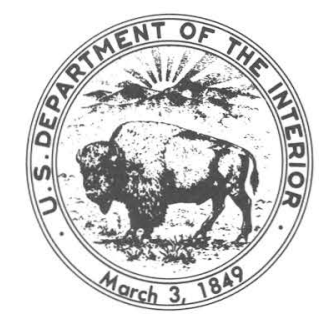

Free on application to the Books and Open-File Reports Section, U.S. Geological Survey, Federal Center,

Box 25425, Denver, CO 80225 


\section{CONTENTS}

Introduction, by Arthur P. Schultz and C. Scott Southworth VII

1. Recent slope movements in Vermont, by Charles A. Baskerville and Gregory C. Ohlmacher 1

2. Landslide susceptibility and processes in the Maryland Coastal Plain, by John S. Pomeroy 5

3. Debris flows triggered by a tropical storm in Puerto Rico, by Randall W. Jibson 9

4. Preliminary results from a study of natural slope failures triggered by the storm of November 3-5, 1985, Germany Valley, West Virginia and Virginia, by Robert B. Jacobson, Elizabeth D. Cron, and John P. McGeehin 11

5. Frequency and susceptibility of debris avalanching induced by Hurricane Camille in central Virginia, by Jeffrey J. Gryta and Mervin J. Bartholomew 16

6. Debris slides and debris flows on Anakeesta Ridge, Great Smoky Mountains National Park, Tennessee, by G. Michael Clark, Patrick T. Ryan, Jr., and Eric C. Drumm 18

7. Block fields, block slopes, and block streams in the Great Smoky Mountains National Park, North Carolina and Tennessee, by G. Michael Clark and C. Allen Torbett III 20

8. Colluvial diamictons in the Valley and Ridge province, West Virginia and Virginia, by J. Steven Kite 21

9. Prehistoric giant rockslides of the Appalachian Valley and Ridge province: Types and characteristics, by C. Scott Southworth 24

10. Failure kinematics of ancient giant rock block slides and rock slumps, southern Appalachian Valley and Ridge province, by Arthur P. Schultz 32

11. Recognition of disaggregated rock block slides in a structurally complex terrane in Virginia, by Thomas M. Gathright II and Eugene K. Rader 21

12. Regional contrasts of landslides in the Appalachian Highlands, by William E. Davies 35

13. Slope instability in the Appalachian Plateaus province, West Virginia: Numerous cases, numerous causes, few cures, by Robert E. Behling 35

14. Relation between landslides and bedrock in the central Appalachian Plateaus, by William F. Outerbridge 36

15. Microcomputer software for comprehensive stability analyses of potential rockslides, by Chester F. Watts 38

16. Sinking Creek Mountain, Virginia, rock block slide complex: Excerpt from the Southeastern Section Geological Society of America Field Trip Road Log, by Arthur P. Schultz $\mathbf{4 0}$

17. Landslide Information Center, by Don Nichols 43 


\section{FIGURES}

1.1. Location map of Vermont 2

1.2. View of Dorset Mountain slide scars as seen on a synthetic aperture radar (SAR) image 3

1.3. Photograph of a portion of the 3.5-mile-long debris flow channel on Dorset Mountain, Vermont 4

2.1. Generalized location map of eastern Maryland showing the Coastal Plain and places referred to in text $\mathbf{5}$

2.2. Photograph of a slope failure in the Patapsco Formation southeast of Baltimore, Maryland 7

2.3. Photograph of a slope failure of Marlboro Clay south of Washington, D.C. 7

2.4. Photograph of slightly tilted old slump surface on Elk Neck peninsula, Maryland 8

2.5. Photograph of steeply dipping stress release joint in the Chesapeake Group clay at Calvert Cliffs, Maryland $\mathbf{8}$

3.1. Isohyetal map of Puerto Rico showing rainfall from tropical storm Isabel, October 6-7, $1985 \quad 10$

4.1A. Isohyetal map of Germany Valley, West Virginia and Virginia, showing rainfall from tropical storm Juan, November 3-5, $1985 \mathbf{1 1}$

4.1B. Isohyetal map of Germany Valley, West Virginia and Virginia, showing total rainfall in October $1985 \mathbf{1 1}$

4.2. Location map of Germany Valley, West Virginia and Virginia, showing quadrangles referred to in text $\mathbf{1 2}$

4.3. Rainfall intensity data of Germany Valley, West Virginia and Virginia, region 13

4.4A. Photograph of slump-mudflows in Germany Valley, West Virginia, triggered by tropical storm Juan 14

4.4B. Photograph of a source-area scar of a debris avalanche in Germany Valley, West Virginia 14

4.5. Aerial photograph of a portion of Germany Valley, West Virginia, showing slump-mudflow scar on pasture slopes 15

5.1. Index map of Nelson County, Virginia, showing the number of debris avalanches related to Hurricane Camille in those quadrangles contained in the study area 16

5.2. Aerial photograph index showing a portion of the area affected by debris avalanches induced by Hurricane Camille in $1969 \quad 17$

5.3. Photograph of the Blue Ridge Mountains, Virginia, showing debris avalanche chutes that resulted from Hurricane Camille in $1969 \quad 17$

6.1. Location map showing the Great Smoky Mountains National Park, Tennessee and North Carolina, and Anakeesta Ridge 18

7.1. Location map of the Great Smoky Mountains National Park, Tennessee and North Carolina, showing block deposits 20

8.1. Stratigraphic cross section of a colluvial fan-alluvial terrace complex near Cabins, West Virginia 22

9.1. Index map to prehistoric giant rockslides in the Appalachian Valley and Ridge province $\mathbf{2 5}$ 
9.2. A, Aerial photograph of the Lost River, West Virginia, debris avalanche. $B$, Aerial photograph of the Mill Ridge, Virginia and West Virginia, rock slump. $C$, Side-looking airborne radar image of Elkhorn Mountain, West Virginia, rock avalanche. $D$, Aerial photograph of a portion of the Sinking Creek Mountain, Virginia, rock block slide complex 28

9.3. $A$, Generalized geologic map of the Lost River, West Virginia, debris avalanche. $B$, Generalized geologic map of the Mill Ridge, Virginia and West Virginia, rock slump. $C$, Generalized geologic map of the Elkhorn Mountain, West Virginia, rock avalanche. $D$, Generalized geologic map of a portion of the Sinking Creek Mountain, Virginia, rock block slide complex 29

9.4. Digital elevation model data of the Elkhorn Mountain, West Virginia, rock avalanche and the Gap Mountain, West Virginia, rock block slide $\mathbf{3 1}$

10.1. Schematic geologic maps and cross sections of typical giant rock block slides and rock slumps in the southern Appalachian Valley and Ridge province 33

11.1. Stereo-pair aerial photographs and geologic map of the Narrows, Virginia, rock block slide complex 34

14.1. Index map of the Jenkins $1^{\circ} \times 2^{\circ}$ quadrangle of Kentucky, West Virginia, and Virginia 36

15.1. Flow chart of ROCKPACK slope stability programs illustrating the recommended sequence of use 39

16.1. Index map and regional geologic map of the Sinking Creek Mountain, Virginia, slide complex $\mathbf{4 0}$

16.2. Detailed geologic map and cross sections of rock block slides and rock slumps on the southeast limb of the Sinking Creek Mountain anticline 41

163. Aerial photograph of part of the Sinking Creek Mountain, Virginia, slide complex 42

\section{TABLES}

2.1. Maryland Coastal Plain stratigraphic units 6

9.1. Characteristics of the four primary types of prehistoric giant rockslides in the Appalachian Valley and Ridge province 26

9.2. Characteristics of named prehistoric giant rock slumps, rock avalanches, debris avalanches, and rock block slides in the Appalachian Valley and Ridge province 27

14.1. Rock types in eastern Kentucky and their typical styles of failure 37 



\section{INTRODUCTION}

\section{Arthur P. Schultz and C. Scott Southworth}

The extended abstracts in this Circular are summaries of papers presented at a symposium on "Landslides of Eastern North America." The symposium was held during the Geological Society of America Southeastern Section meeting in Norfolk, Virginia, on March 26, 1987. The purpose of the symposium was to develop working models of landslide processes in the various geologic and physiographic provinces of Eastern North America. Geologists from academia, State geological surveys, and the U.S. Geological Survey who are presently engaged in studies of slope failures participated in the symposium. Presentations on a wide variety of geologic and physiographic settings of all types of landslides in Eastern North America were welcomed.

Slope failures resulting from single, high-rainfall events were included in this symposium. Geologic settings of slope failures range from areas where high slopes are underlain by metamorphic and (or) clastic sedimentary rocks to areas where gentle slopes are underlain by coastal sediments. Several papers discuss the influence of periglacial climate on mountain slope deposits in the Appalachian Highlands. Stable weathering mechanics and stratigraphy of Appalachian mountain slope deposits are presented. Ancient giant rockslides of the Appalachian Valley and Ridge province are discussed with special emphasis on the kinematics of failure. Landslide types in specific physiographic provinces are presented, and landslide processes are related to climate, bedrock type, geologic structure, and slope disturbance caused by man. The importance of computer applications to slope stability models is the final contribution to the symposium. A field trip guide of the Sinking Creek Mountain, Virginia, rockslide complex, part of the Southeastern Geological Society of America premeeting field trip, is included. A description of the Landslide Information Center of the U.S. Geological Survey and a list of its goals are provided to further the exchange of landslide information.

It is hoped that this collection of articles will stimulate continued study of landslides in Eastern North America and open cooperative projects of interdisciplinary nature related to slope failures. 



\title{
LANDSLIDES OF EASTERN NORTH AMERICA
}

\author{
Arthur P. Schultz and C. Scott Southworth, editors
}

\section{RECENT SLOPE MOVEMENTS IN VERMONT}

\section{Charles A. Baskerville and Gregory C. OhImacher}

Recent slope movements in Vermont, studied from the spring of 1983 through the fall of 1986, included debris slides and flows in till and glacial sand and gravel deposits, earth flows and slumps in glacial lake clays, as well as rock falls, block slides, and debris slides on bedrock slopes. Slope classifications are after Varnes (1978). Of the many slope movements investigated, the debris flows at Dorset Mountain (figs. 1.1-1.3) and the large rock falls at Smugglers Notch near Stowe were the most spectacular.

Only a few slope failures were found in the northeastern part of the State, on the basis of both field and remotely sensed reconnaissance. For example, soils are generally coarse boulder tills derived mostly from the large area of igneous rock found there. Most of the coarse glacial soils found here do not have the usual clay-silt content found in other areas where failures are common, so drainage during heavy precipitation takes place.

Standard aerial photographic, synthetic aperture radar (SAR) (fig. 1.2), and some infrared photographic images were examined for evidence of recent slope movements, such as soil slopes with rills and exposed bedrock cliffs ( $>10 \mathrm{~m}$ ). In addition, slope configurations indicative of potential failure, such as steep $\left(>27^{\circ}\right)$ soil-covered slopes, and evidence of older slope movements, such as old headscarps and hummocky slopes, were identified. Field investigations verified what we saw on the remotely sensed images and also located historic and recent slope movements that were not obvious on the images. Geologic and engineering data, such as areal measurements, thicknesses of slide masses, types of deposit, material types, and estimates of material strength, were collected in the field to help determine the causes and mechanics of failure.

The largest number (about 60 percent) of slope movements occurred in clayey glacial till on steep to moderately steep (100 percent -45 percent) slopes. The distribution of clayey till appears to be related to micaceous schists and phyllites, common in the Silurian and
Devonian formations in eastern Vermont. Slope failures were also common in the rhythmite deposits of clayey glacial lakebeds. These include the deposits of the ancient glacial Lake Hitchcock, the clays of which crop out along the Connecticut River valley and in the lower reaches of its tributaries (fig. 1.1). Clay rhythmite deposits of smaller glacial lakes at higher elevations, such as those along the Connecticut River valley (Stewart and MacClintock, 1969), were also found to be slide prone. Mechanical analyses showed the soils involved in the slope movements to contain anywhere from 2 to 90 percent silt- and clay-sized particles.

Failures on bedrock slopes generally developed in highly jointed or foliated rocks where the major joint sets or foliation planes are parallel to the free faces of cliffs. In areas of slope movements, these joint or foliation surfaces generally are nearly vertical; some of these surfaces either dip into or parallel the slope face. Freeze-thaw action along these surfaces of weakness over a number of winters was found to move large masses of rock.

Intense precipitation is the major factor contributing to most of the Vermont slope failures. Heavy rains associated with Hurricane Belle triggered four debris flows on the southern side of Dorset Mountain (figs. 1.1-1.3) in 1976 (Ratté and Rhodes, 1977). Several heavy rainstorms in May and June of 1984, which followed a period of above-normal precipitation, caused numerous slope movements throughout central Vermont as well as other sites around the State. In May 1986, several debris flows and rock falls occurred at Smugglers Notch near Stowe (fig. 1.1) as a result of a late spring storm (Burlington Free Press, 1986).

The slope movements that occurred in 1984 followed a period of above-normal precipitation (from a low of 3 to a high of nearly 10 inches a month) that began during the fall of 1983 (National Oceanic and Atmospheric Administration, 1983, 1984). This precipitation saturated the soils, raised the ground-water table, and 


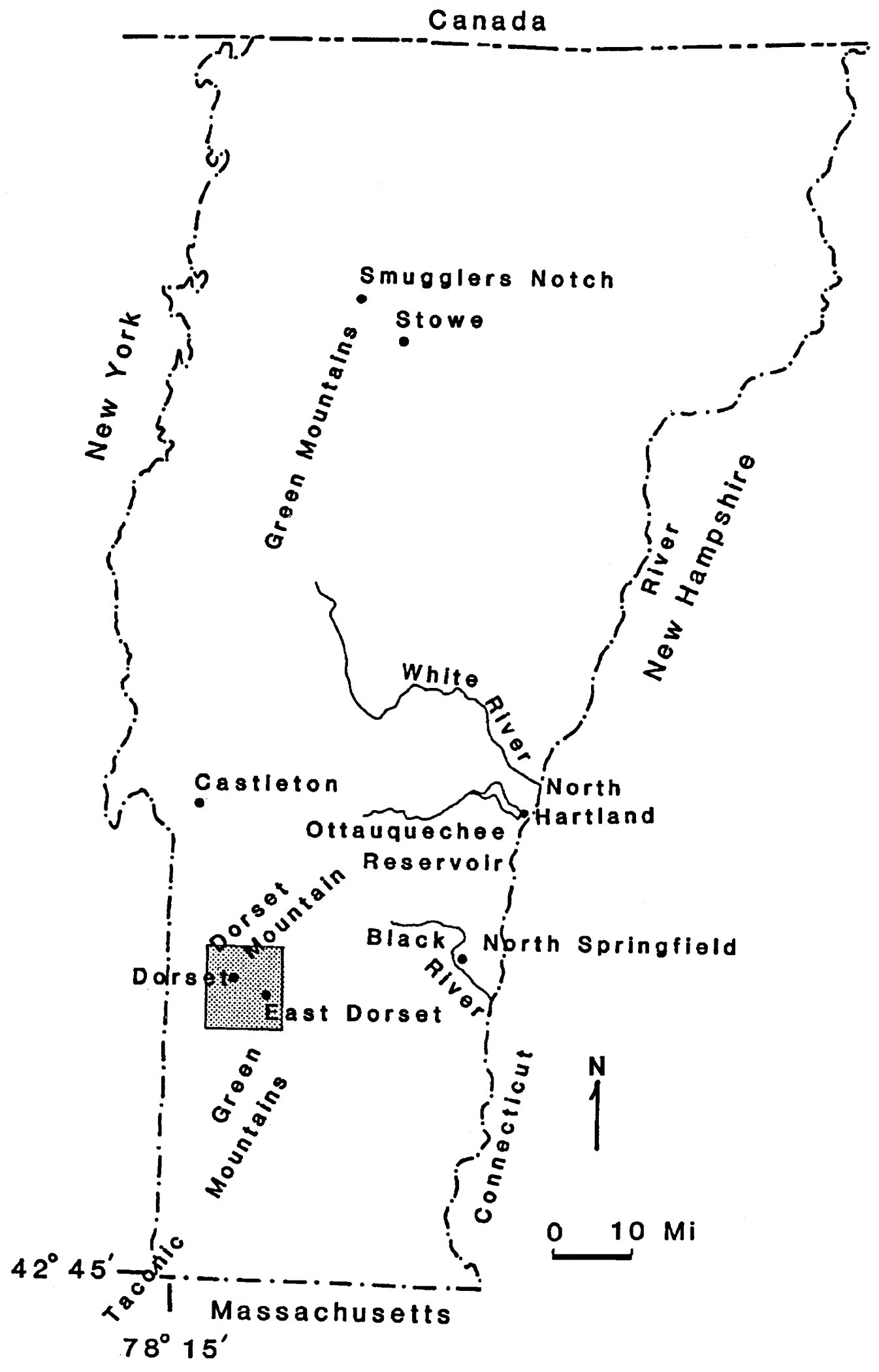

Figure 1.1. Location map of Vermont showing places referenced in the text. The shaded box is index to figure 1.2. 


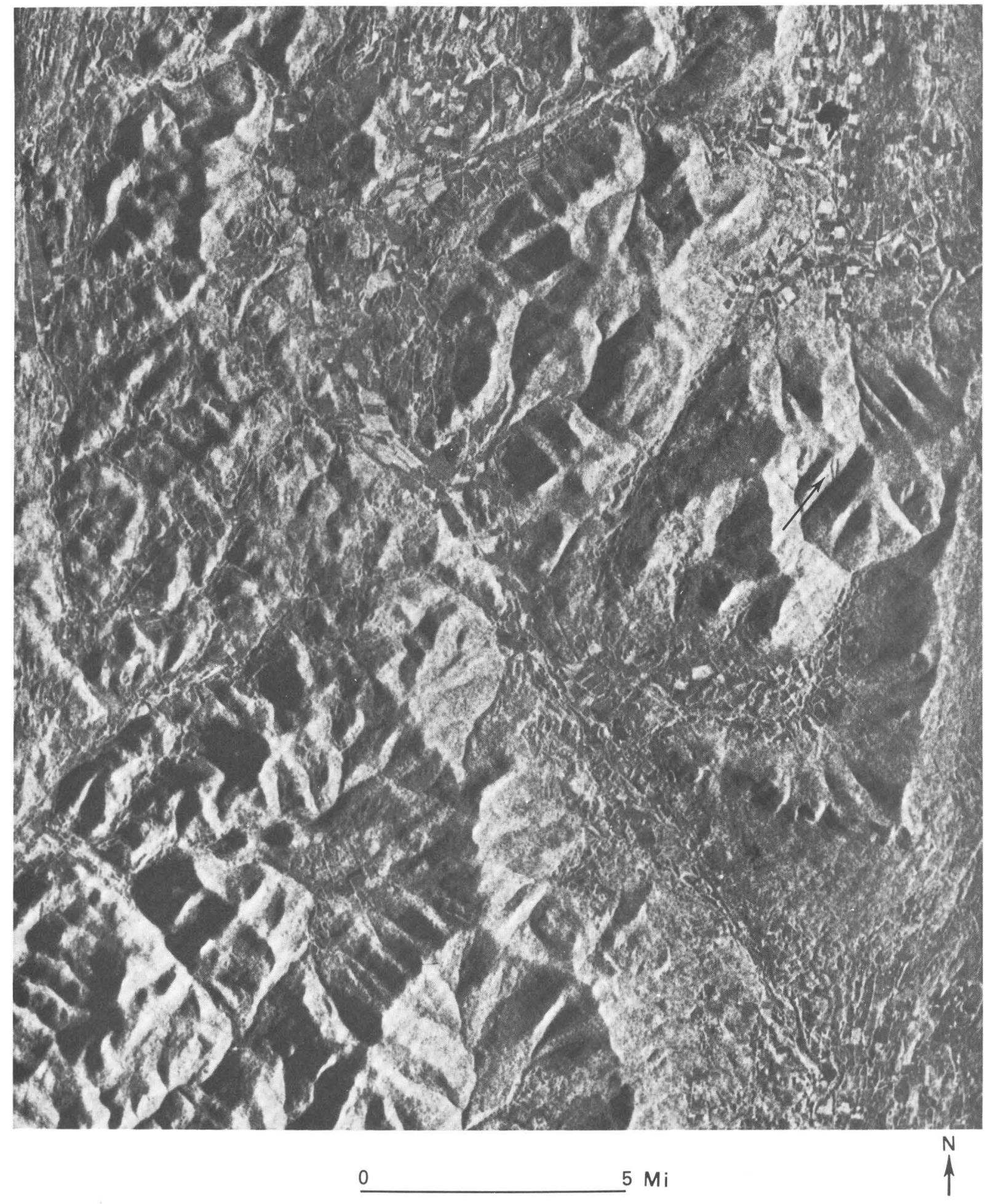

Figure 1.2. View of Dorset Mountain slide scars (arrow) as seen on a synthetic aperture radar (SAR) image. The location of this feature is on the east side of the village of Dorset. See figures 1.1 and 1.3. 


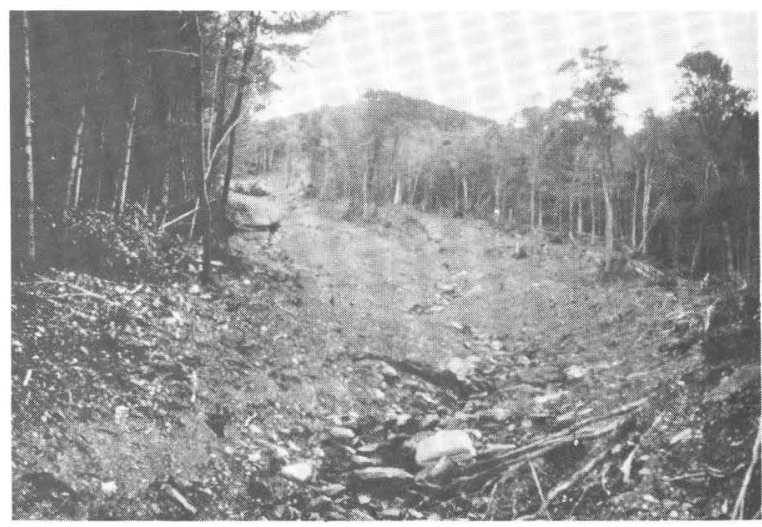

Figure 1.3. View of a portion of the 3.5-mile-long debris flow channel on Dorset Mountain.

thus elevated pore water pressures in these soils. The May and June 1984 storms contributed an average of 11 inches of precipitation in central Vermont alone, triggering numerous earth flows and block slides. These storms also elevated the pool levels behind several flood control dams. As levels in reservoirs were subsequently drawn down, the rate of lowering of the ground-water table discharging from the soils could not keep pace with the falling pool levels, so earth flows resulted, which Terzaghi (1950) described elsewhere. One earth flow in the Ottauquechee Reservoir (fig. 1.1) exposed a very permeable sand deposit. Water escaping from this permeable unit removed some of the sand so as to leave piping cavities within the layer.

Debris flows have occurred throughout the Green and Taconic Mountains. The most recent debris flows occurred in 1986 at Smugglers Notch. There were at least five separate debris flows along a 1-mile stretch of Vermont Route 108, which traverses the Notch. The largest of the flows, which measured 2,300 feet $(700 \mathrm{~m})$ along its axis, traveled across the road and cut off all traffic through the Notch. These failures occurred as a result of nearly continuous rains in late May of 1986. According to the records, precipitation was 0.13 in. on May 20, 0.73 in. May 21, 0.64 in. May 22, 2.42 in. May 23, and 0.52 in. on May 24 (Mr. Edward Salvas, station WCAX-TV on Mount Mansfield, Vt., pers. commun.). A similar series of debris flow failures occurred in weathered schists on the south side of Dorset Mountain in 1976 (figs. 1.2 and 1.3). The Dorset Mountain debris flows traveled about 3.5 miles and involved hundreds of thousands of cubic yards of rock, soil, and trees covering 100 acres.

Among the most catastrophic slope movements studied in Vermont were rock falls and debris flows. At Smugglers Notch, blocks of very hard schist, weighing as much as 11,000 tons, were involved in rock falls in 1983 and again in 1986. A block that fell in 1983 did not come down onto the roadway; however, blocks from older rock falls were deposited along both sides of the road. The only fall of record to close the Notch was that of May 1986 (Burlington Free Press, 1986). Although the exact cause of failure is uncertain, it is felt that time-dependent fracture propagation driven by gravity, freeze-thaw action, fluid pressure in joints, or a combination of these may have been involved. A potentially hazardous rock fall is in the Cheshire Quartzite at East Dorset (fig. 1.1). Here the cliff face is densely jointed and is continually moving down and outward. The movement of this mass is being monitored and has shown at least a foot of settlement in 2 years (F.T. Lee, 1986, pers. commun.). The cliff face has developed a "sackungen" (Radbruch-Hall and others, 1976), or gravitational spreading (bowed), appearance.

Slope movements found in surficial deposits included earth flows, rotational slides (slumps), and debris slides. Most of the slope movements involving glacial lakebed rhythmites were of the earth flow type (Ohlmacher and Baskerville, 1985). These flows were numerous in the steep banks adjacent to flood control reservoirs and on steep faces of terraces along the Connecticut and Black Rivers (fig. 1.1). Although the dominant failure mode was earth flow, rotational sliding was observed in a few cases, notably near North Springfield (fig. 1.1). Another example of a large slump involved clayey glacial till located near Castleton (fig. 1.1). This slump has been active continually for several years (Charles A. Ratté, Vermont State Geologist, pers. commun.). Debris slides in glacial tills, outwash deposits, and kames have been observed by the authors throughout Vermont. Most are caused either by streams undercutting their banks or by the oversteepening of cut slopes along road shoulders.

\section{ACKNOWLEDGMENTS}

This paper resulted from work done as part of a cooperative project between the U.S. Geological Survey and the Vermont Geological Survey. We deeply appreciate the assistance given us by the U.S. Army Corps of Engineers at the North Hartland and North Springfield flood control dam sites and the U.S. Forest Service at Manchester Center, Vermont.

\section{REFERENCES CITED}

Burlington Free Press [Burlington, Vermont], 1986, Mudslide closes Vermont 108 in Smugglers Notch: May 24, 1986, no. 144, p. 18.

National Oceanic and Atmospheric Administration, 1983, Climatological data New England, September to December 1983: v. 95, nos. 9-12.

- - 1984, Climatological data New England, January to June 1984: v. 96, nos. 1-6. 
Ohlmacher, G.C., and Baskerville, C.A., 1985, Slope movements on fluidized zones in varved deposits of glacial Lake Hitchcock, Windsor County, Vermont: The Geological Society of America, Abstracts with Programs, v. 17, no. 7, 1985 Annual Meeting, p. 680.

Radbruch-Hall, D.H., Varnes, D.J., and Savage, W.Z., 1976, Gravitational spreading of steep-sided ridges ("sackung") in western United States: Bulletin of the International Association of Engineering Geology, no. 14, p. 23-35.

Ratté, C.A., and Rhodes, D.D., 1977, Hurricane induced landslides on Dorset Mountain, Vermont: The Geological
Society of America, Abstracts with Programs, v. 9, no. 3, Northeast Annual Meeting, p. 311.

Stewart, D.P., and MacClintock, Paul, 1969, The surficial geology and Pleistocene history of Vermont: Vermont Geological Survey, Department of Water Resources, Bulletin no. 31, 251 p.

Terzaghi, Karl, 1950, Mechanism of landslides, in Application of geology to engineering practice (Berkey volume), Geological Society of America, p. 83-123.

Varnes, D.J., 1978, Slope movement types and processes, in Landslides Analysis and Control, Schuster, R.L., and Krizek, R.J. , eds., Transportation Research Board, Special Report 176, p. 11-33.

\section{LANDSLIDE SUSCEPTIBILITY AND PROCESSES IN THE MARYLAND COASTAL PLAIN}

\section{John S. Pomeroy}

Slope failures take place in virtually all of the exposed Cretaceous, Tertiary, and Quaternary units in the Coastal Plain of Maryland (fig. 2.1). Susceptibility to landsliding ranges from very low (post-Potomac Group Upper Cretaceous units and Aquia Formation, table 2.1) to very high (Potomac Group clays and Marlboro Clay, table 2.1, figs. 2.2, 2.3). Susceptibility to landsliding is defined as the probable degree of response of the unconsolidated stratigraphic units and their derivative soils to natural events or to artificial slope modifications. Clay layers within the stratigraphic units have caused stability problems.

In order to gain a better understanding of the geologic environment and mass movement processes, slope movements were mapped in suburban Prince Georges County in both the relatively steeply sloping (high relief) terrane of the southwestern part and the more gently sloping (low relief) terrane of the eastern part. Geologic maps by Glaser $(1978,1981,1984)$ facilitated the investigation. Ground traverses were also conducted in highly slide-prone areas southwest of Baltimore and along the west side of Elk Neck peninsula at the head of Chesapeake Bay. Most of the shoreline comprising the Cakvert Cliffs along the west side of Chesapeake Bay was examined at least twice during the study.

Slope movements in both the Potomac Group and Marlboro Clay are either slumps, earth flows, or a combination of the two forms. The present investigation suggests that heretofore undocumented large old slumps (fig. 2.4) along Elk Neck peninsula might have been induced by faulting. On the basis of an interpretation of aeromagnetic data, pre-Miocene(?) faulting in this region has been inferred by Higgins and others (1974). One old slumpearth flow is still moving and is responsible for a $200-\mathrm{m}$ wide zone of accretion along a shoreline where elsewhere erosion is the dominant geomorphic process. An array of landslide types along the Cakert Cliffs in the Chesapeake

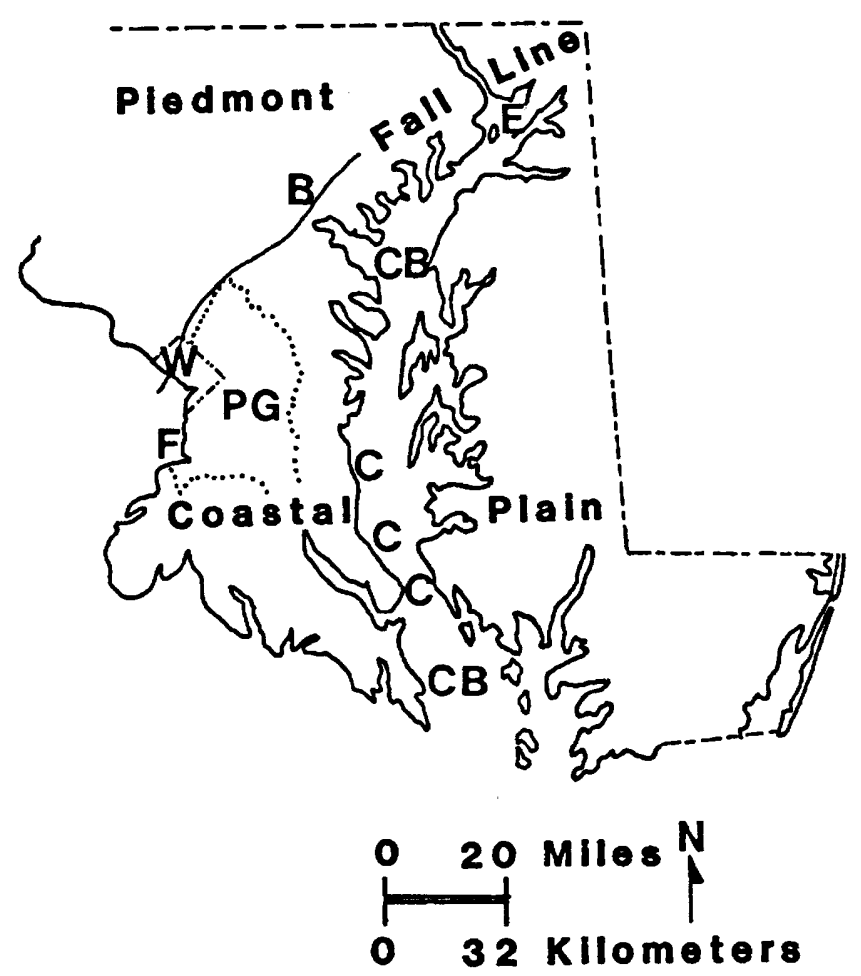

Figure 2.1. Generalized location map of eastern Maryland showing the Coastal Plain and places referred to in text. B, Baltimore; C, Calvert Cliffs; CB, Chesapeake Bay; E, Elk Neck peninsula; F, Fort Washington; PG, Prince Georges County; W, Washington, D.C.

Group (table 2.1) includes ubiquitous spalls; soil, sand, and earth falls; and translational slides. Topples, slumps, and debris flows are less common.

Large old landslides are commonly difficult to discern, on the basis of morphologic criteria, but a few, as much as $200 \mathrm{~m}$ wide, are identifiable in terranes underlain by the Potomac Group clays. Large blocks on the Aquia Formation, which forms a shoreline bluff of low relief 
Table 2.1. Maryland Coastal Plain stratigraphic units (modified from Cleaves and others, 1968; Glaser, 1971)

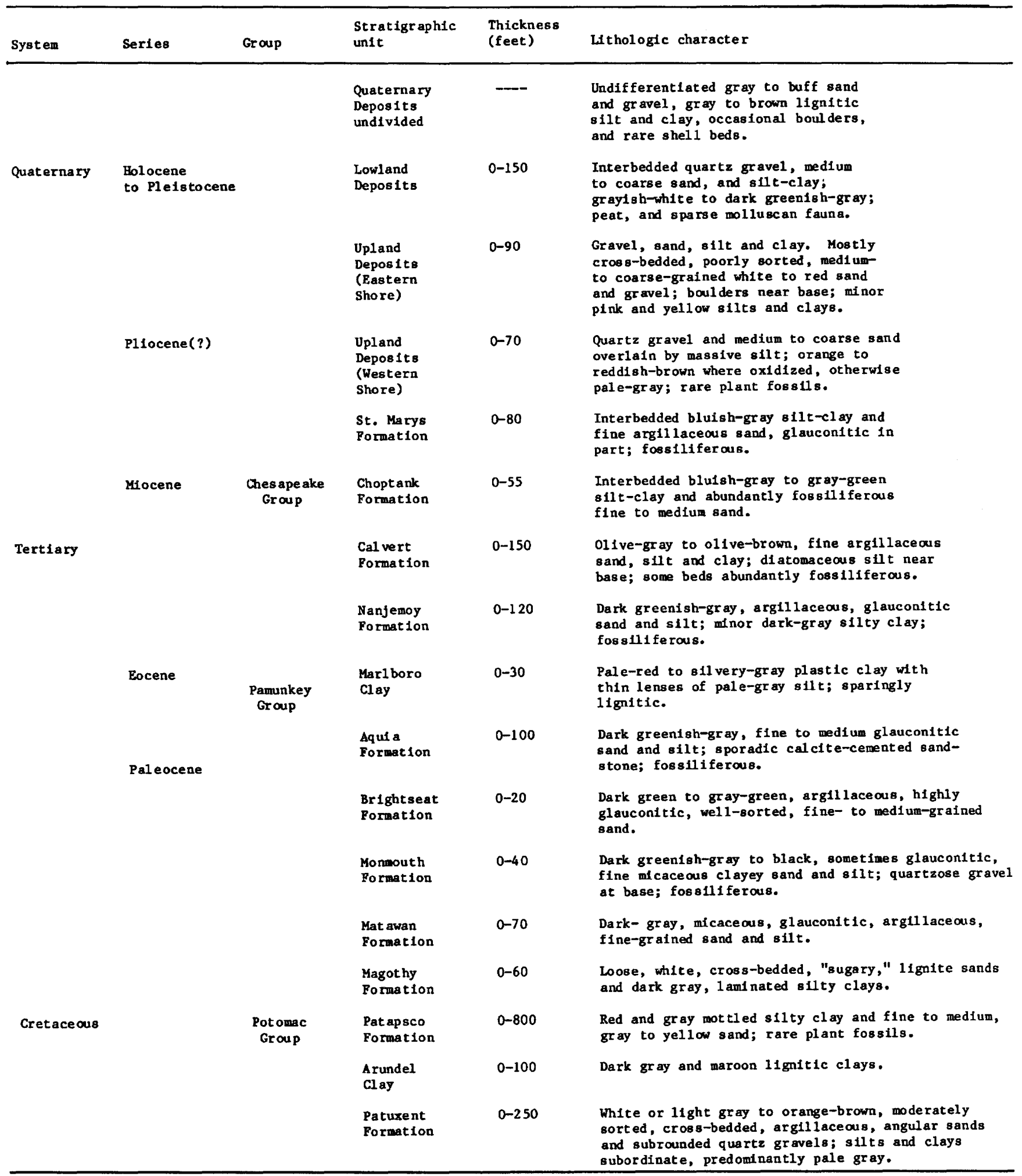




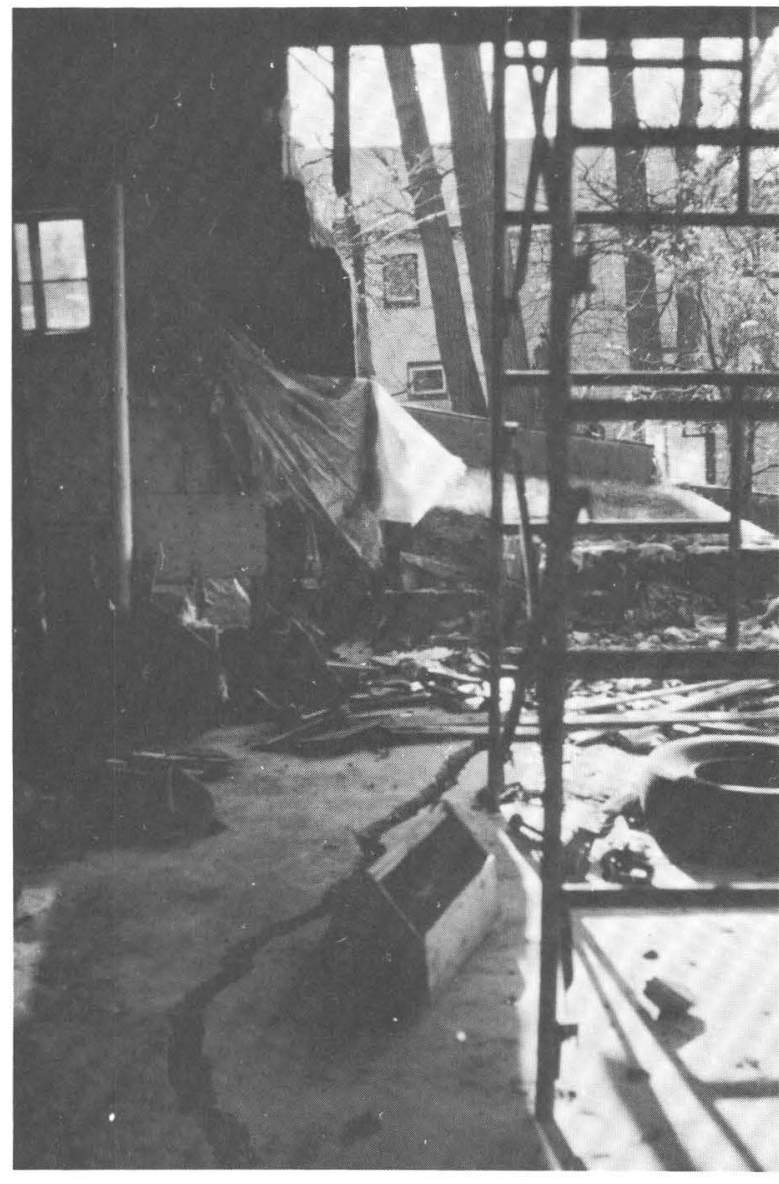

Figure 2.2. Slope failure in Patapsco Formation southeast of Baltimore. Note the floor crack in the concrete slab and the slanted trees.

adjacent to Potomac Group clays at Fort Washington, attest to prehistoric slumping. In another example near the head of Chesapeake Bay, Upper Cretaceous marine glauconitic sands occupy an interval $150 \mathrm{~m}$ wide along the shoreline between exposures of the Lower and Upper Cretaceous Patapsco Formation (table 2.1).

The vast majority of slope failures relate either directly or indirectly to precipitation, and the relationship is complex. Long periods of abnormally high precipitation are more likely to initiate slope movements than isolated summer thunderstorms of high intensity but of short duration. High pore pressures in the soil are caused by rising ground-water levels. Slope failures generally take place when the ground-water table is high.

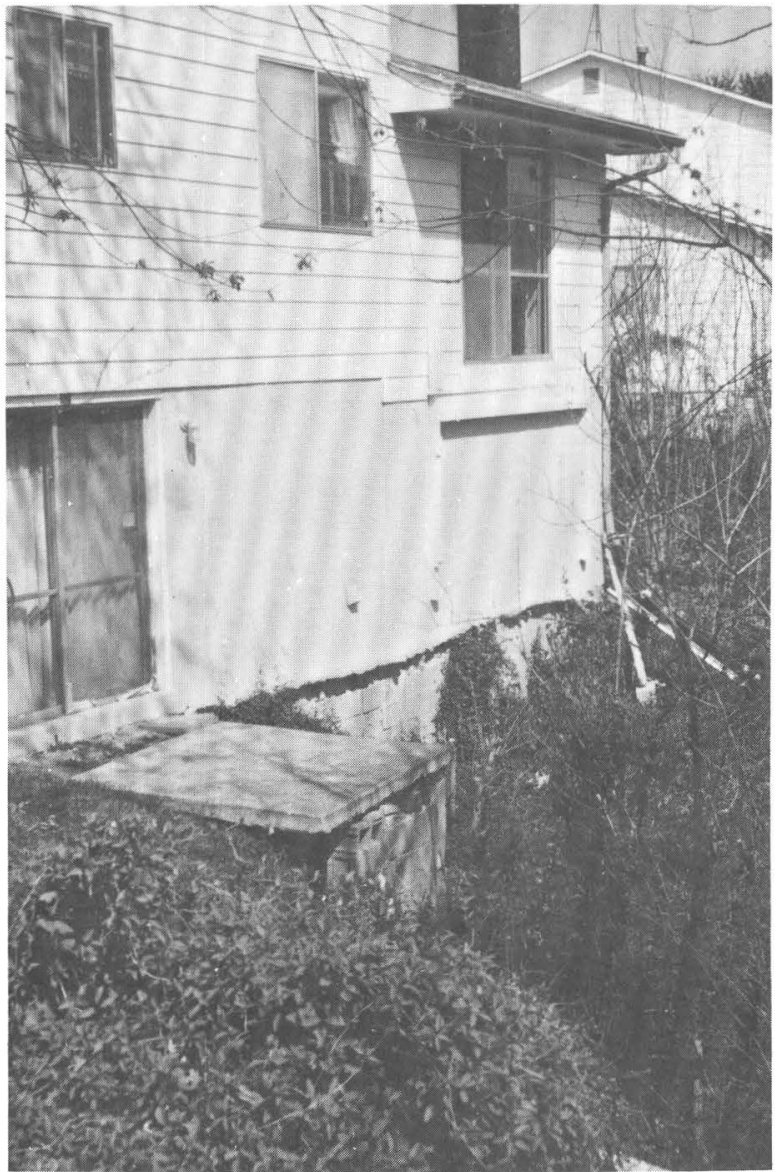

Figure 2.3. Failure of Marlboro Clay and overlying fill in backyard south of Washington, D.C.

Climatic records for the Maryland Coastal Plain (National Oceanic and Atmospheric Administration, 1960-1986) indicate that the 1960 's generally were drier than normal, whereas the period beginning with 1971 and extending to the end of that decade had been wetter than normal. High summer rainfall in 1972, 1975, and 1979 was caused by a combination of drenching rains from tropical storms together with abnormally high rainfall at other times during the same season. Several residential subdivisions developed during the 1960's in southwestern Prince Georges County did not experience landsliding until the 1970's. Significant landsliding took place at one subdivision during and after a tropical storm in September 1975. Major landslide activity has not taken place 


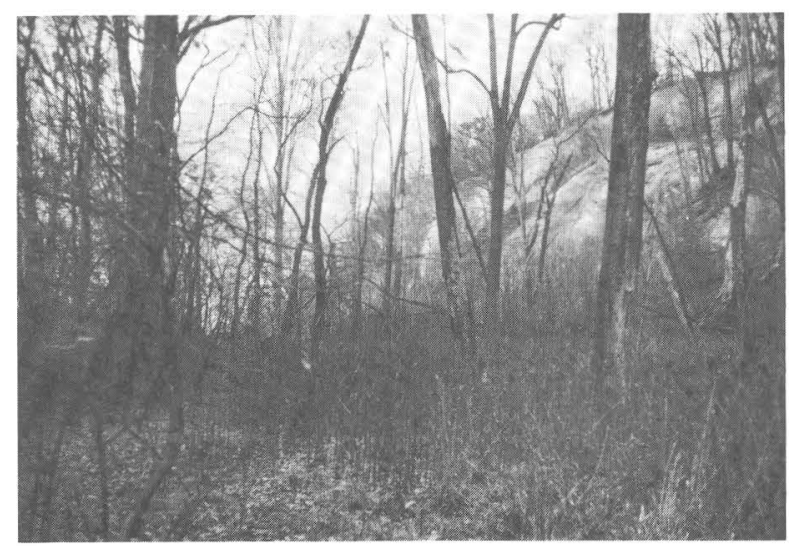

Figure 2.4. Slightly tilted old slump surface overlying Potomac Group clay, Elk Neck peninsula at head of Chesapeake Bay. Bare steep slope in background is head scarp.

there since that time despite a record maximum discharge at a nearby creek in September 1979 following a tropical storm (U.S. Geological Survey, 1980) and an unusually wet spring in 1983. A possible explanation for the cessation of major landslide activity might be that the slopes have adjusted to the surface modification resulting from construction in the 1960's and, therefore, have reached a state of equilibrium. Precipitation during the $1980-86$ period has been below normal except for 1983 .

The landsliding process takes place in the zone of weathering. All units susceptible to sliding have high-angle joints (Obermeier and others, 1984). Depending upon moisture conditions and a relative position of a clay horizon in the section, a perched water table commonly lies above the impermeable layer. Seeps are widespread at this contact along the slope face. The clay surface may serve as a slide surface when water percolates through the overlying more permeable sand or silt and moves laterally, lowering frictional resistance, to the slope face. Not all failures, however, begin at this position. Fractures in the clay allow for downward migration of water. Thin horizontal and vertical silt zones within a clay unit (WoodwardClyde Consultants, 1976) become conduits for water and may also serve as loci for landsliding.

Nowhere is the slope movement process more clearly seen than in excavations and pits, especially in early spring. Elsewhere, shallow surface excavations made with a trenching tool along minor drainages at this time of year reveal the development of "minislides" where the contact of the permeable cover and underlying clay horizon is exposed. The Calvert Cliffs furnish a dynamic environment for observing various forms of slope failure. Ground-water seepage is present at several places along the Calvert Cliffs. This process induces sapping of loose noncoherent sand and silt lying above the line of seepage.

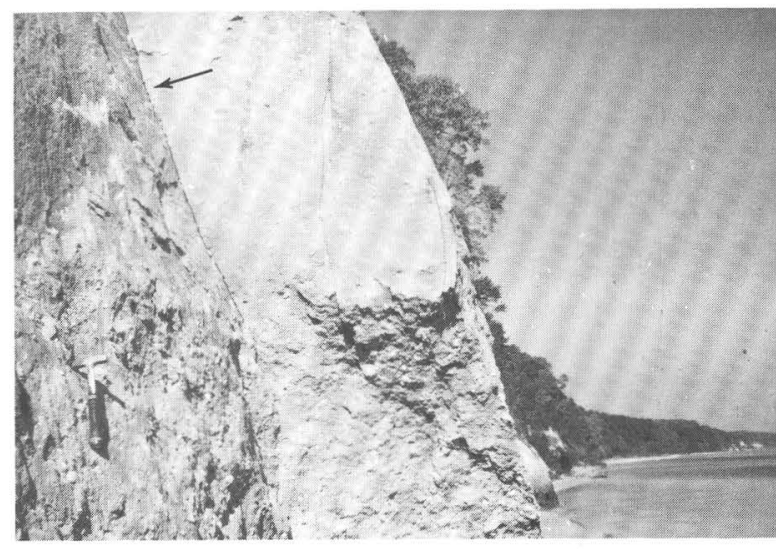

Figure 2.5. Steeply dipping stress release joint in fossiliferous silty clay, Chesapeake Group, Calvert Cliffs. Slickensides along joint face indicate planar movement.

The removal of support of the overlying sediments results in a collapse failure. Translational (planar) movements at shallow depths controlled by subvertical stress release joints may result from the failure of the overlying, mainly sandy material. Spalling takes place both above and below the seepage line along subvertical joints dipping steeply toward Chesapeake Bay (fig. 2.5). This process is continuous throughout the year but accelerates during the cooler months when freezing and thawing occur along the joints.

Wave action can induce slope failure by a removal of material from the toe of the slope. Observations at various time intervals have led to the conclusion that a series of closely spaced spalls above the beach can lead to massive failure of the overlying slope material.

\section{REFERENCES CITED}

Cleaves, E.T., Edwards, Jonathan, Jr., and Glaser, J.D. (compilers), 1968, Geologic map of Maryland: Maryland Geological Survey, scale 1:250,000.

Glaser, J.D., 1971, Geology and mineral resources of southern Maryland: Maryland Geological Survey Report of Investigations $15,84 \mathrm{p}$.

- - - 1978, Geologic map of the Mount Vernon and Piscataway quadrangles, Maryland: Maryland Geological Survey, scale $1: 24,000$.

_- - 1981, Geologic map of the Upper Marlboro quadrangle, Prince Georges County, Maryland: Maryland Geological Survey, scale 1:24,000.

- - - 1984, Geologic map of the Bristol quadrangle, Prince Georges, Anne Arundel, and Calvert Counties, Maryland: Maryland Geological Survey, scale 1:24,000.

Higgins, M.W., Zietz, Isidore, Fischer, G.W., 1974, Interpretation of aeromagnetic anomalies bearing on the origin of Upper Chesapeake Bay and river course changes in the central Atlantic seaboard region-speculations: Geology, v. 2 , no. 2 , p. $73-76$. 
National Oceanic and Atmospheric Administration, 1960-1985, Climatological Data, Annual Summary, Maryland: National Climatic Data Center, Asheville, N.C., v. 64-89, no. 13.

Obermeier, S.F., Swanson, P.G., Jones, J.S., Jr., and Schnabel, J.J., 1984, Engineering geology and design of slopes for Cretaceous Potomac deposits in Fairfax County, Virginia and vicinity: U.S. Geological Survey Bulletin 1556, 88 p.
U.S. Geological Survey, 1980, Water resources data for Maryland and Delaware: U.S. Geological Survey Water-Data Report MD-79, 398 p.

Woodward-Clyde Consultants, 1976, Geotechnical investigation, Chalfont Avenue landslide, Forest Knolls subdivision, Prince Georges County, Maryland: Rockville, Maryland, 20 p., plates and appendix.

\section{DEBRIS FLOWS TRIGGERED BY A TROPICAL STORM IN PUERTO RICO}

\section{Randall W. Jibson}

On October 5-8, 1985, a tropical wave, which later developed into tropical storm Isabel, produced extraordinary rainfalls on the island of Puerto Rico. At some places, the 24-hr rainfall exceeded $560 \mathrm{~mm}$ (fig. 3.1), and local intensities reached $70 \mathrm{~mm} / \mathrm{hr}$. The storm center was over the south-central coast, where the intense rainfall caused severe flooding and widespread landsliding. By far the most abundant type of slope movement produced by this rainfall was debris flow-the mobilization and flow of water-saturated rock and soil down steep slopes, commonly in preexisting gullies or depressions. The majority of the thousands of debris flows triggered by the storm of October 5-8 occurred within the $400-\mathrm{mm}$ isohyet (fig. 3.1), although other debris flows were scattered over much of south-central Puerto Rico (Jibson, 1986).

Debris flows generated by the storm were not limited to a particular topographic or geologic setting, but rather formed on slopes having a wide variety of topographic characteristics, lithologies, and geologic structures. The flows in Puerto Rico formed on slopes underlain by limestone, mudstone, volcanic rock, and granitic rock; on dip slopes, reverse-dip slopes, jointed and unjointed rock masses; and on planar as well as irregular slopes. Locally, however, geologic factors did influence the distribution of debris flows, such that on some hillsides, debris flows were initiated along the outcrop of a particularly susceptible lithologic unit.

Most of the debris flows developed on bedrock slopes covered by a veneer of colluvium and (or) residuum no more than 1 to $2 \mathrm{~m}$ deep. Some debris flows formed in preexisting swales or gullies, others on relatively planar slopes. Even those debris flows that were generated in preexisting gullies, however, were mobilized in areas having only thin accumulations of surface soils. This differs significantly from other documented processes of debrisflow initiation, such as the evacuation of deep, colluviumfilled bedrock hollows in California (Reneau and others, 1986). Debris-flow source areas in south-central Puerto Rico generally were disk shaped; diameters were as great as $15 \mathrm{~m}$, and thicknesses ranged from 0.5 to $1.5 \mathrm{~m}$.

After mobilization, the debris generally flowed down preexisting drainage gullies or depressions on the hillsides.
In most flows, the debris scoured the overlying colluvium down to bedrock, and in flows where preexisting gullies were filled with thick accumulations of colluvium, the debris scoured channels as deep as $7 \mathrm{~m}$. On many slopes composed of mudstone, deeply incised drainage channels were present before the debris flows formed. The flowing debris further incised and eroded these drainage channels, which destabilized the gully walls and resulted in additional thin debris slides into the channel. These secondary debris slides contributed substantial mass to the debris flow. These two processes, channel scouring and incision triggering slide-slope debris sliding, contributed most of the material to the final debris-flow deposits. The volume of material from source areas at the heads of the debrisflow tracks generally constituted no more than 5 percent of the total volume of the debris-flow deposits.

Most of the debris flows appear to have been triggered by buildup of pore pressure resulting from the intense, prolonged rainfall of October 5-8. Of those flows well constrained in time, all developed during peak rainfall intensity, early in the morning hours of October 7. Several flows formed at or near the slope break marking the boundary between nearly vertical bedrock faces above and steep colluvium-covered slopes below; it thus appears that the infiltration of sheetwash from the overlying bedrock face elevated pore pressures enough to mobilize the soil at the tops of the colluvium-covered slopes.

In one area about $10 \mathrm{~km}$ west of Ponce (fig. 3.1), field evidence indicates that a debris flow was triggered by rock falls onto the top of a colluvium-covered slope. At this site, a $40^{\circ}$ colluvial slope containing several debrisflow tracks abuts a vertical-to-overhanging limestone bedrock face. All the debris-flow tracks head directly below fresh rock-fall scarps in the limestone, and the boulders that failed are visible in the deposits at the base of the hillside. The uppermost parts of the debris flows at this site are distinctive from other debris-flow source areas in the region: only a portion of the colluvium beneath the rock-fall scarps mobilized, and bedrock is not exposed; only farther downslope has scouring exposed bedrock at the site. This evidence and other field evidence indicate that the debris flows here were triggered by rock falls onto 


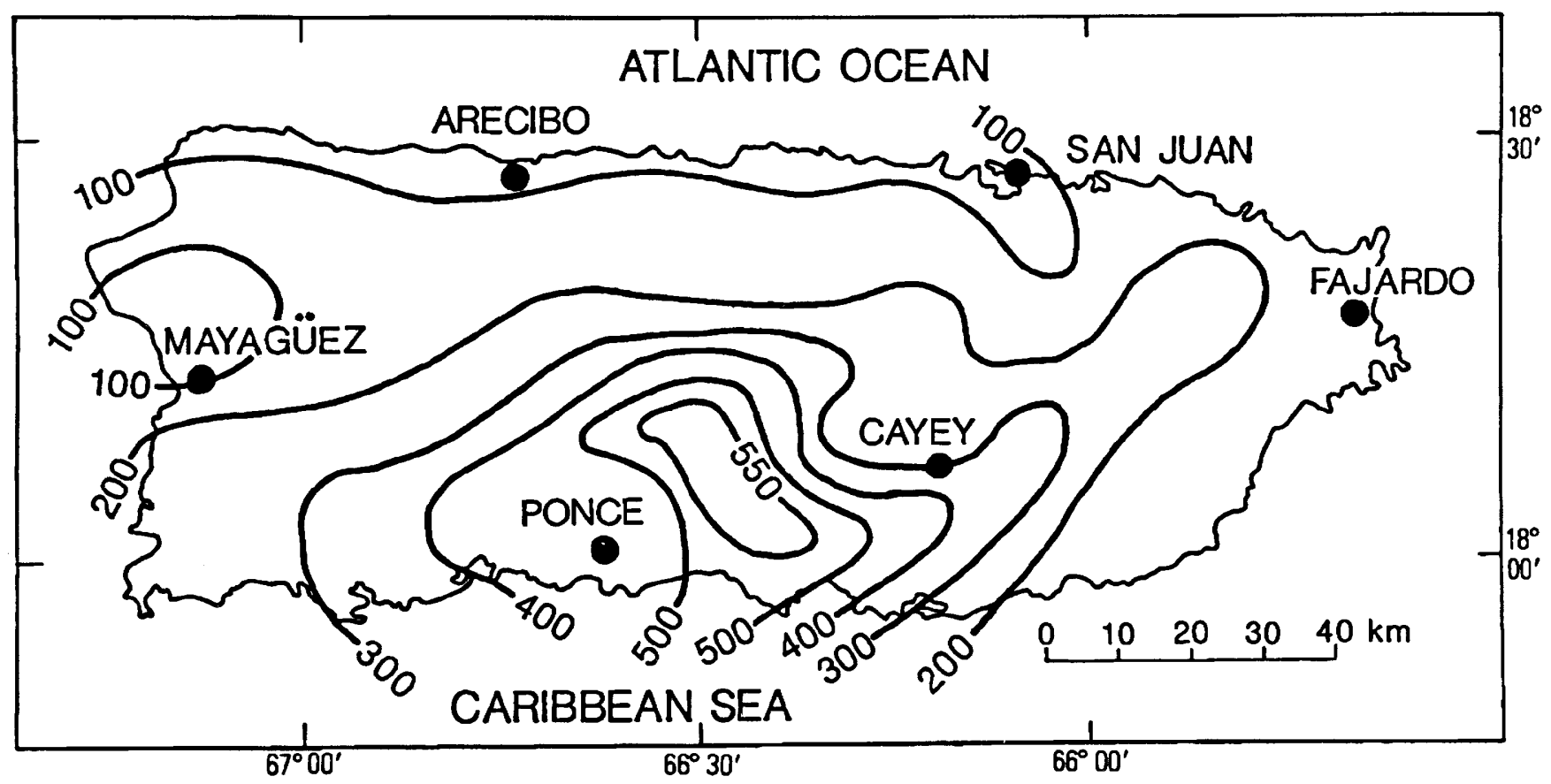

Figure 3.1. Map showing 24-hour rainfall amounts (in millimeters) throughout Puerto Rico from 8:00 a.m. (local time) October 6 to 8:00 a.m. October 7, 1985 (from U.S. Geological Survey, 1985). Isohyet intervals 50 and $100 \mathrm{~mm}$.

the top of the colluvium-covered slope that either (1) generated a large, instantaneous increase in pore pressure leading to mobilization or (2) mechanically disaggregated the saturated colluvium, which then began to flow downslope.

Analysis of geologic, climatic, and topographic data bases in Geographic Information System (GIS) format is proceeding that will allow quantification of factors related to debris-flow distribution from the storm. Understanding both the factors influencing debris-flow distribution and the mechanisms of debris-flow initiation, propagation, and deposition will facilitate modeling and prediction of the relative susceptibility to debris-flow hazards of different areas subjected to a given model storm.

\section{REFERENCES CITED}

Jibson, R.W., 1986, Evaluation of landslide hazards resulting from the 5-8 October 1985, storm in Puerto Rico: U.S. Geological Survey Open-File Report 86-26, 40 p.

Reneau, S.L., Dietrich, W.E., Dorn, R.I., Berger, C.R., and Rubin, Meyer, 1986, Geomorphic and paleoclimatic implications of latest Pleistocene radiocarbon dates from colluvium-mantled hollows, California: Geology, v. 14, no. 8, p. 655-658.

U.S. Geological Survey, 1985, Water resources in Puerto Rico and the Virgin Islands-a review: Caribbean District of the Water Resources Division, v. 4, no. 7, 7 p. 


\section{PRELIMINARY RESULTS FROM A STUDY OF NATURAL SLOPE FAILURES TRIGGERED BY THE STORM OF NOVEMBER 3-5, 1985, GERMANY VALLEY, WEST VIRGINIA AND VIRGINIA}

\section{Robert B. Jacobson, Elizabeth D. Cron, and John P. McGeehin}

\section{INTRODUCTION}

During the first five days of November 1985, a low-pressure system in the Ohio River valley combined with a low-pressure system referred to as Tropical Storm Juan to produce heavy rainfall in the Potomac, James, and Rappahannock River basins. Severe flooding accompanied the rainfall; 43 lives were lost and the flood was estimated to be the most expensive natural disaster of 1985 in the United States (Scatena, 1986).

The rainfall also triggered many slope failures. An especially large concentration of slope failures was associated with an area of moderate rainfall centered in the Germany Valley in Pendleton County, West Virginia (fig. 4.1A). This report describes some preliminary results from our continuing research into the geological and meteorological controls on the distributions of slope failures in the Germany Valley area.

The Germany Valley is the first major anticlinal valley in the Valley and Ridge province east of the Allegheny structural front (Diecchio, 1986). Our interest is focused on the portion from near Mouth of Seneca, West Virginia, in the Onego 7.5-minute quadrangle, to near Mill Gap, Virginia, in the Mustoe 7.5-minute quadrangle (patterned in figs. 4.1 and 4.2). This area was a natural experiment for studying the effects of the storm because rainfall varied systematically from southwest to northeast along the valley, while bedrock lithology and structure are nearly constant. Furthermore, variation of rock types across the valley allows comparisons among lithologies at given levels of precipitation.

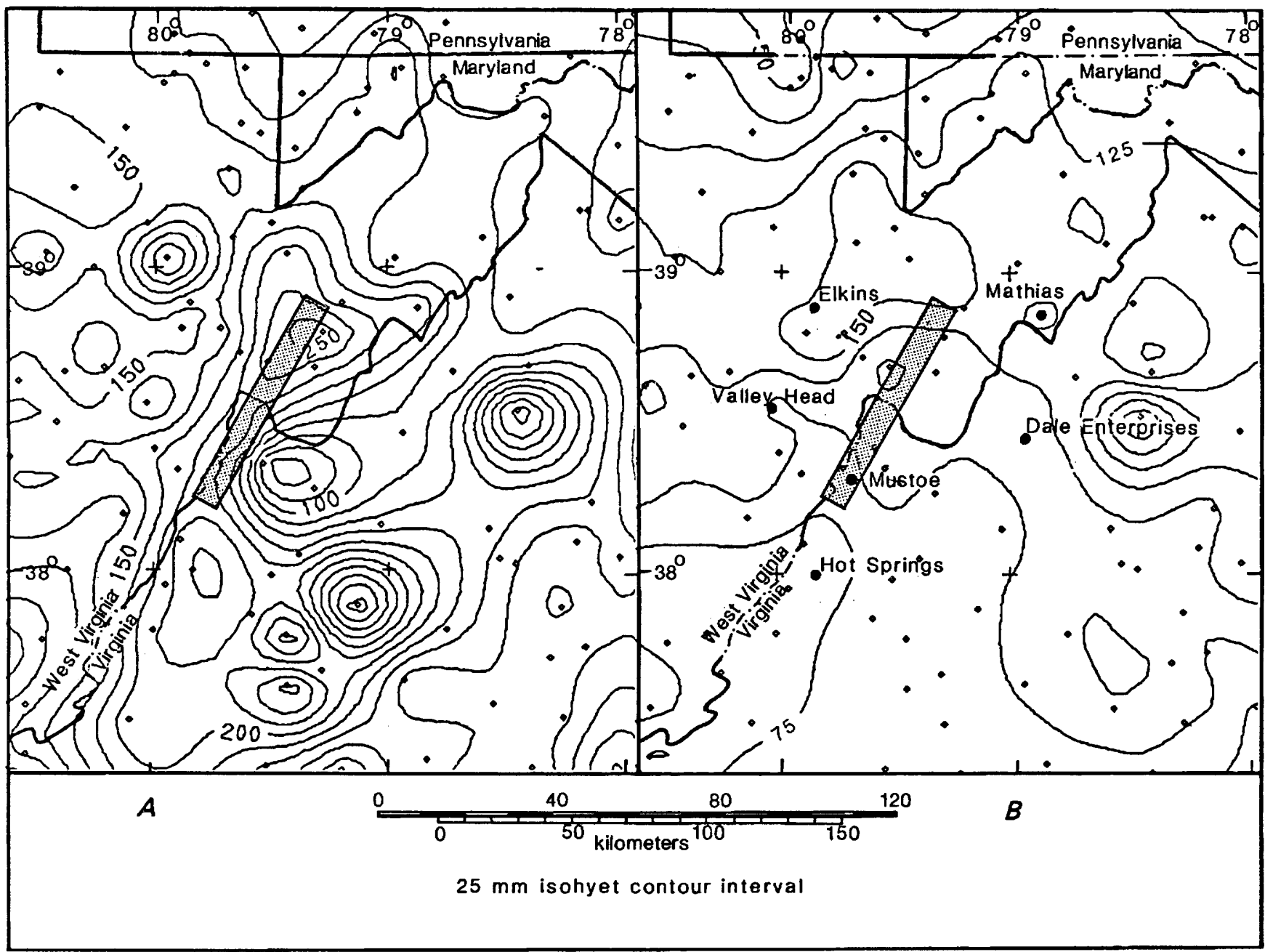

Figure 4.1. A, Storm-total isohyetal map, November 3-5, 1985. Shaded area is the Germany Valley study area. Diamonds are rain gage locations. $B$, Isohyetal map for total rainfall in October 1985. Also shown are locations of six hourly recording rain gages (๑) whose data are shown in figure 4.3 . 


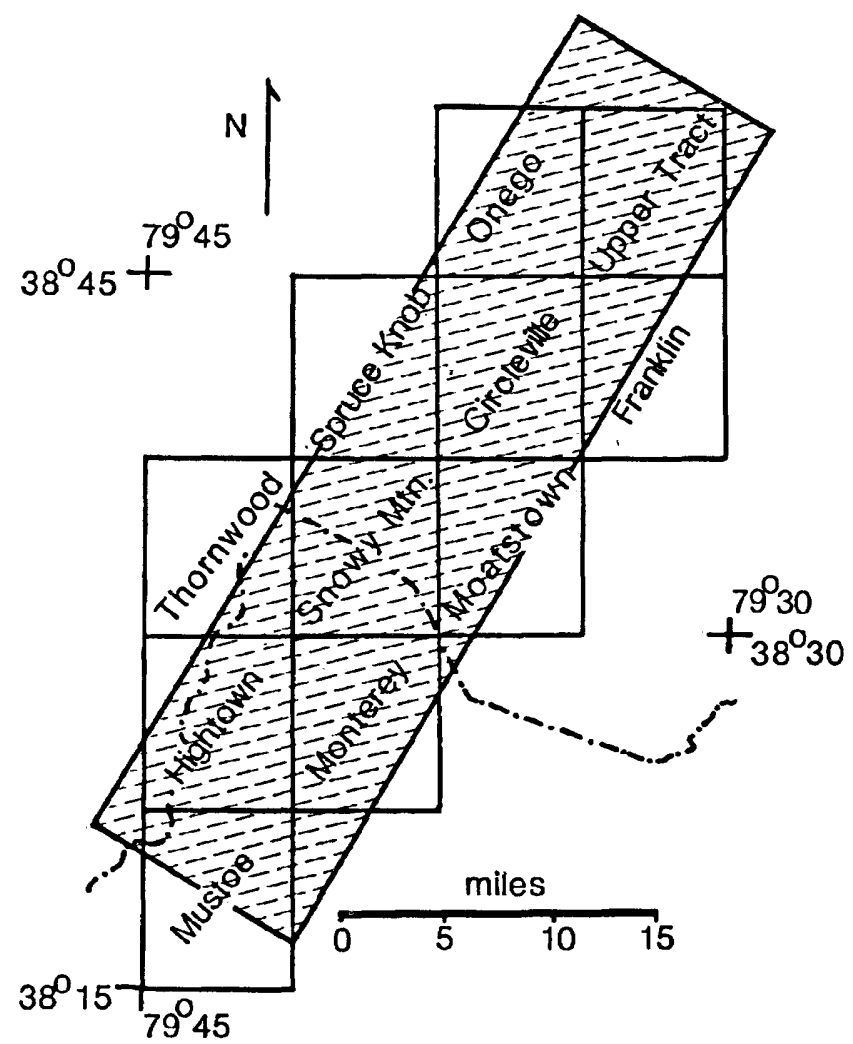

Figure 4.2. Location map of Germany Valley study area showing quadrangles referred to in text.

The valley is floored by Ordovician carbonates of the Trenton, Black River, and St. Paul Groups and shales of the Martinsburg (Reedsville) Shale. The ridges are formed by sandstones of the Tuscarora and Oswego Sandstones, and the Juniata Formation. The southwestern quarter of the valley is drained by Back Creek of the James River basin, and the remainder of the valley drains north and west to the North Fork of the South Branch Potomac River.

\section{CHARACTERISTICS OF THE STORM}

Moisture conditions preceding the storm of November $1-5$ are illustrated in figure $4.1 B$, which shows isohyets of total rainfall during October 1985. During this period, the northeastern end of the study area received nearly twice as much rainfall as the southwestern end. The isohyetal map for storm-total rainfall, November 3-5 (fig. $4.1 A$ ), shows that the rainfall distribution was dominated by two strong cells along the Blue Ridge Mountains (Montebello and Big Meadows gages received more than $350 \mathrm{~mm}$ and $300 \mathrm{~mm}$, respectively); a more moderate cell is evident in the northern part of the patterned study area. The southern half of the study area received approximately $200 \mathrm{~mm}$ of rainfall during the storm; just north of the State line, rainfall increases gradually to somewhat greater than $250 \mathrm{~mm}$ (Upper Tract gage was $268.7 \mathrm{~mm}$ ).
Rainfall intensity measurements by hourly recording rain gages are widely scattered (fig. 4.1B). Data indicate that peak rainfall intensities near Germany Valley were low $(7.6-38.3 \mathrm{~mm} / \mathrm{h})$ but that appreciable rain fell almost continually from midnight of November 4 to mid-morning of November 5 (fig. 4.3). Compared to Hurricane Camille in 1969, these rainfall values are not high. In Nelson County, Virginia, Camille produced 300 to $700 \mathrm{~mm}$ of rain in 7 to 8 hours; peak hourly intensities were 37.5 to 87.5 $\mathrm{mm} / \mathrm{h}$ (Williams and Guy, 1973).

Runoff from the November storm caused severe flooding in the Potomac and James River drainage basins. Many of the gages on the South Branch Potomac River reported record floods having estimated recurrence intervals in excess of 100 years (Lescinsky, 1986).

\section{SLOPE FAILURES}

We have classified slope failures triggered by the November storm into two general categories: (1) slumps and slump-mudflows and (2) debris avalanches-debris flows (after Varnes, 1978). Slump-mudflows are shown in figure $4.4 A$, and a debris avalanche scar is shown in figure 4.4B. Slumps have rotational to planar sliding movement at their heads; when fine-grained sediment flows from a slump, it is termed a slump-mudflow. The feature in the center of figure $4.4 A$ is a slump-mudflow that has had the slump block partially removed from the head by flowage. The mass of flowing muddy sediment has moved downslope over pasture turf, depositing a trail of sediment as lateral levees and a hummocky mass at the snout. The slope failure to the right in the photo is also a slumpmudflow but here most of the original slump block has remained intact. The term debris avalanche is used here to denote a slope failure that begins as a rapid slide of noncoherent rock or regolith; most debris avalanches become debris flows as they funnel into preexisting channels downslope. Although there are no eyewitness accounts of the debris avalanches described here, evidence that debris masses ran up on the outside walls of bends suggests that they had considerable velocity.

Slumps and slump-mudflows triggered by the November 3-5 storm are abundant on slopes underlain by residuum of the Martinsburg Shale and some slopes underlain by carbonates. The aerial photograph in figure 4.5 shows a small drainage basin in the northern half of the Circleville 7.5-minute quadrangle where failures in Martinsburg Shale residuum are especially numerous. Close inspection of figure 4.5 shows that many slumpmudflows delivered sediment directly to streams, an observation that has led us to hypothesize that stream channel erosion and flood damage are closely tied to upstream slope failures. Preliminary observations also suggest that, for failures triggered by this storm, there are no generally preferred slope aspects and that more failures occurred on pasture land than on forest-covered slopes. 

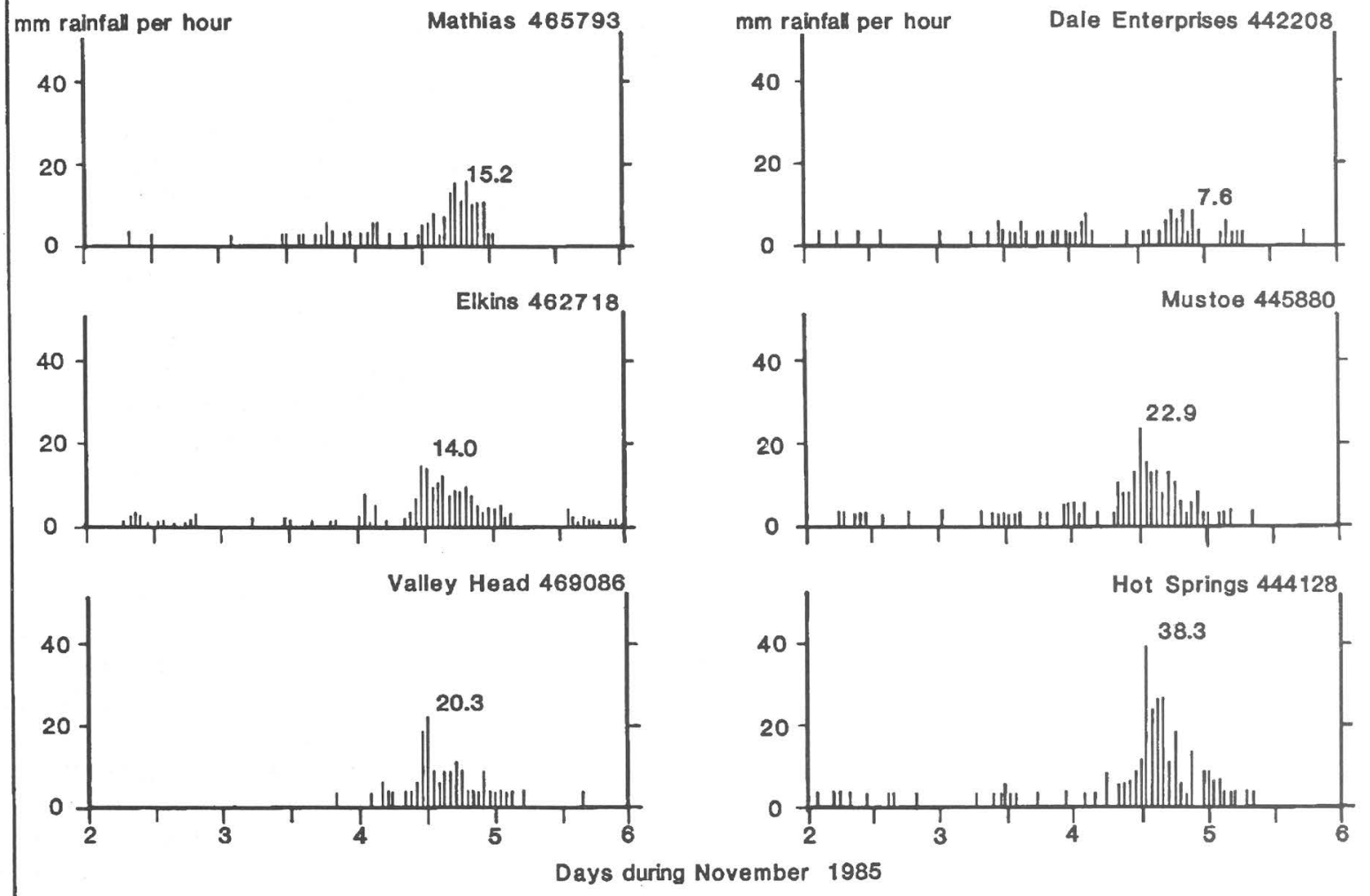

Figure 4.3. Rainfall-intensity data from hourly recording rain gages. Data are in $\mathrm{mm} / \mathrm{h}$, with peak value noted.

All types of failures are virtually absent on the clean, karstic limestones of the St. Paul Group, and slumps and slump-mudflows are rare on slopes underlain by residuum and colluvium of the sandy lithologies underlying ridges.

Five large debris avalanches-debris flows were triggered in the study area by the November storm; all had source areas high on ridge slopes underlain by sandstones of the Tuscarora Sandstone and Juniata Formation. They are much larger than individual slump-mud flows, with source-area scars larger than $100 \mathrm{~m}^{2}$. In traveling downslope (exceeding hundreds of meters distance), the debris avalanches converted to debris flows and scoured channels to bedrock. Significantly, four of the five debris avalanches began on dip slopes (fig. 4.4B). Such slopes may be more susceptible to slope failure under given meteorologicalconditions because slip is facilitated along bedding planes. Also, it is interesting that the source area of the debris avalanche (fig. 4.4B) began as a planar rock block slide which preferentially removed bedrock instead of adjacent old colluvium shown in the lower right foreground of the photo. The fifth debris avalanche was initiated on a scarp slope at the contact between the Tuscarora and the Juniata. Landowners who lost their turkey shed to this debris flow reported that it occurred at dusk on November 4. This observation is coincident with the timing of the peak rainfall intensity recorded at Mathias, West Virginia, the nearest hourly-recording rain gage (fig. 4.3).

Within the Germany Valley study area, the distribution of slope failures is strongly related to the distribution of rainfall. Although our analysis is incomplete at this time, slope failure density (number of failures per unit area) clearly increases to the northeast along the valley, coincident with increasing rainfall. Preliminary failure density estimates for slopes underlain by Martinsburg show a steady increase from approximately $14.5 / \mathrm{km}^{2}$ in the Mustoe quadrangle to $45.2 / \mathrm{km}^{2}$ in the Snowy Mountain quadrangle to $81.8 / \mathrm{km}^{2}$ in the Circleville quadrangle (fig. 4.2). The proportion of failures delivering sediment to streams also apparently increases with increasing precipitation. 


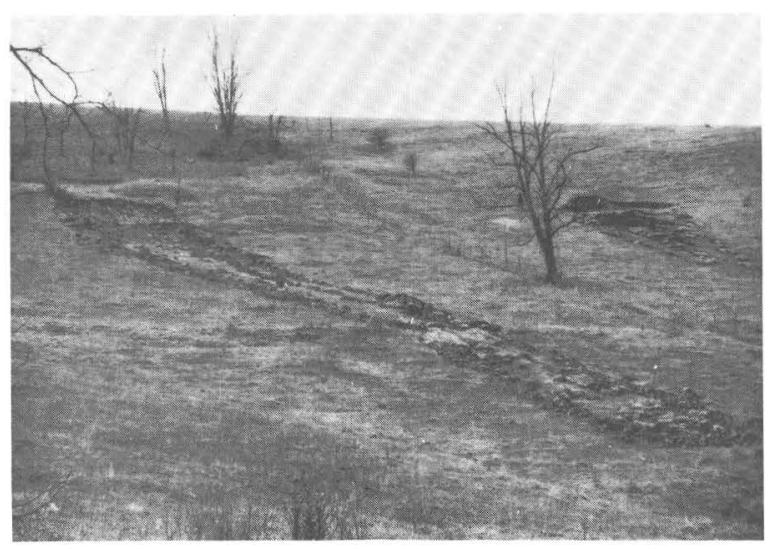

Figure 4.4A. Slump-mudflows triggered by the November storm on gentle slopes underlain by fine-grained residuum weathered from the Martinsburg Shale.

\section{PRELIMINARY CONCLUSIONS AND CONTINUING RESEARCH}

Our continuing research in this area will employ an automated geographic information system (GIS) to develop quantitative tests for hypotheses relating failures triggered by the storm to meteorologic and geologic variables. Until we have completed the more rigorous analysis our observations indicate the following preliminary results: (1) The type and number of slope failures triggered by the November 1985 storm were strongly controlled by the underlying lithology; fine-grained residuum from the Martinsburg Shale and some Ordovician carbonates were more susceptible to failure under conditions of this low-intensity storm than were colluvium and residuum of the sandier lithologies. Slumps and slumpmudflows on fine-grained regolith are smaller but more numerous than the rare, large debris avalanche-debris flows occurring on the sandier lithologies. (2) A slopeaspect preference is not readily apparent; fewer failures on tree-covered slopes may indicate that trees play an important role in stabilizing these slopes. (3) Because four out of five debris avalanches (occurring in an area where rainfall intensity probably did not vary widely) initiated on dip slopes on the Tuscarora Sandstone, it is evident that these dip slopes are significantly more susceptible to failure under these meteorological conditions than comparable scarp slopes. (4) Association of stream-channel damage with the presence of upstream slope failures suggests that sediment from slope failures influences downstream erosion, deposition, and general flood damage. (5) Slope failure density increases with increasing storm-total rainfall along a transect where lithology and structure are constant.

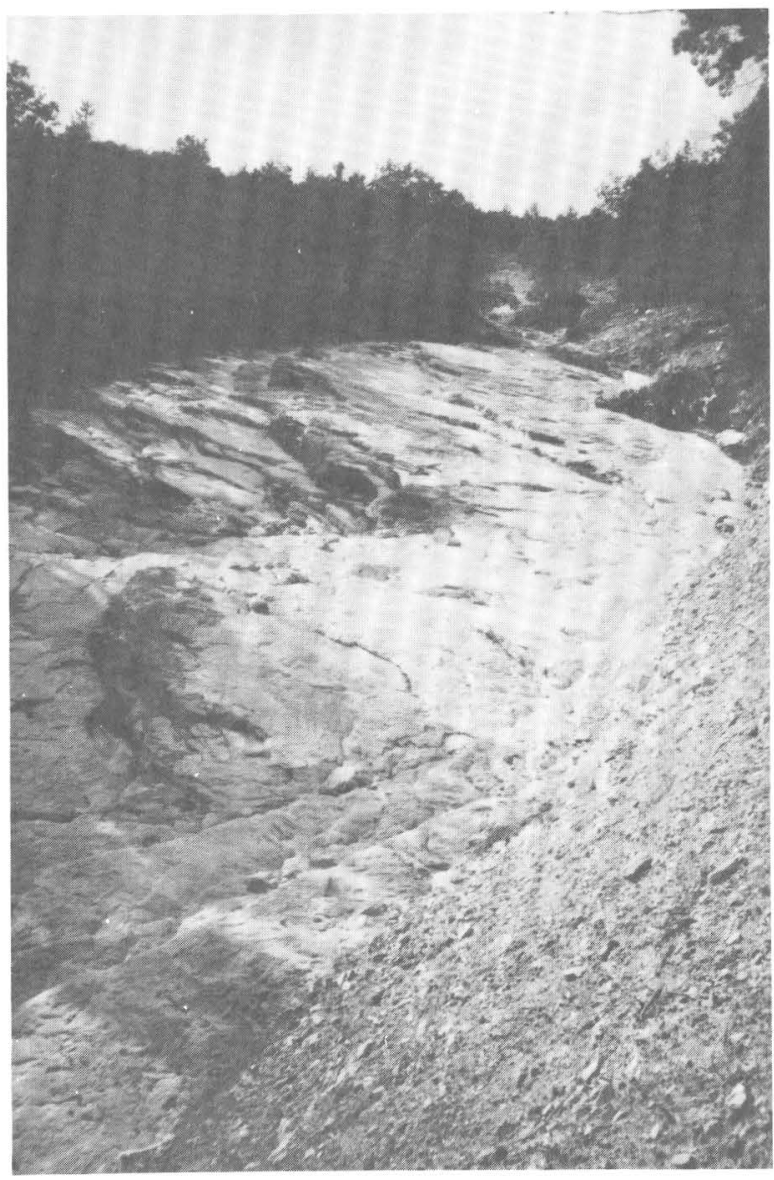

Figure 4.4B. Source-area scar of a large debris avalanche in Upper Tract 7.5-minute quadrangle, West Virginia. This failure began on a $36^{\circ}$ dip slope underlain by Tuscarora Sandstone.

Figure 4.5. Aerial photograph of a small drainage basin underlain by Martinsburg Shale in the Circleville 7.5-minute quadrangle, West Virginia. Many failures can be seen on pastured slopes; a high proportion are slump-mudflows that delivered sediment directly to stream channels.

\section{REFERENCES CITED}

Diecchio, Richard J., 1986, Taconian clastic sequence and general geology in the vicinity of the Allegheny Front in Pendleton County, West Virginia: Geological Society of America Centennial Field Guide -Southeastern Section, p. 85-90.

Lescinsky, J.B., 1986, Flood of November 1985 in West Virginia, Pennsylvania, Maryland, and Virginia: U.S. Geological Survey Open-File Report 86-486, 33 p.

Scatena, F.N., 1986, Floodplain reconnaissance study, November 1985 flood, Potomac River Basin: Baltimore, Md., The 


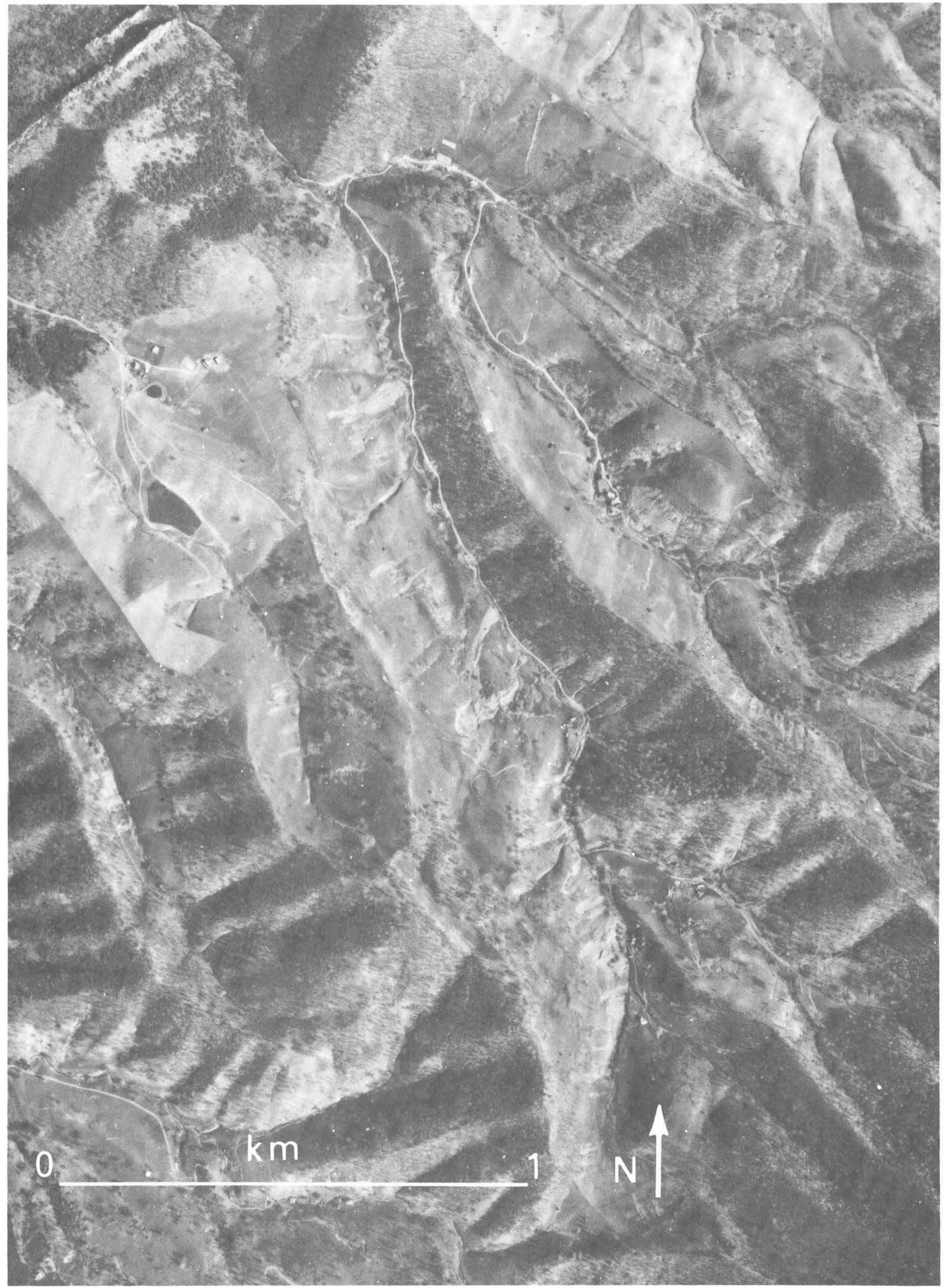


Johns Hopkins University, Department of Geography and Environmental Engineering, unpub. report to the Interstate Commission on the Potomac River Basin, 45 p.

Varnes, D.J., 1978, Slope movements and types and processes, in Landslides: analysis and control: Washington, D.C.,
National Academy of Sciences, Transportation Research Board, Special Report no. 176, p. 11-33.

Williams, G.P., and Guy, H.P., 1973, Erosional and depositional aspects of Hurricane Camille in Virginia, 1969: U.S. Geological Survey Professional Paper 804, 80 p.

\title{
5. FREQUENCY AND SUSCEPTIBILITY OF DEBRIS AVALANCHING INDUCED BY HURRICANE CAMILLE IN CENTRAL VIRGINIA
}

\author{
Jeffrey J. Gryta ${ }^{1}$ and Mervin J. Bartholomew ${ }^{2}$
}

During August 1969, Hurricane Camille dumped 27 to 28 inches of rain in 8 hours over Nelson County, Virginia, resulting in extensive debris avalanche activity (Williams and Guy, 1971). Williams and Guy suggested that debris avalanche activity was not bedrock controlled. Inadequate definition of the basement rocks at the time of their study precluded interpretations involving associations between debris avalanche occurrence and bedrock type. Debris avalanche activity associated with Hurricane Camille occurred within several localized areas in the vicinity of Nelson County. To assess landslide susceptibility as related to bedrock, a much broader area was studied, one in which bedrock geology has been mapped and which encompasses the localized areas of avalanching. Consequently, all avalanche chutes occurring in the Nelson County area, identified on 1:40,000-scale 1971 aerial photographs (figs. 5.1 and 5.2), were plotted on 7.5minute geologic quadrangle maps based on geology taken from Bartholomew and Lewis (1984). Landslide susceptibility was based on bedrock geology as well as slope aspect.

Preliminary results indicate that nearly 1,100 debris avalanches were triggered within approximately a 405 $\mathrm{km}^{2}$ area, resulting in an average of 2.7 debris avalanches per square kilometer. The greatest concentration of debris avalanching occurred within the Horseshoe Mountain and Lovingston 7.5-minute topographic quadrangles (fig. 5.1). Three susceptibility classes were defined on the basis of debris avalanche frequency: slight (0-2 landslides/square kilometer), moderate (2-7 landslides/square kilometer), and high (greater than 7 landslides/square kilometer). Data suggest that 5 of the 12 bedrock units identified in the area are particularly susceptible to debris avalanching. The Crossnore Complex plutonic rocks are highly susceptible to debris avalanche activity, the Archer Mountain Suite of Sinha and Bartholomew (1984) is moderately susceptible, while the Pedlar River Charnockite Suite of Sinha and Bartholomew (1984), Stage Road Layered

\footnotetext{
${ }^{1}$ Department of Geology, Kent State University, Kent, $\mathrm{OH} 44242$.

${ }^{2}$ Montana Bureau of Mines and Geology, Montana Tech., Butte, MT 50801.
}

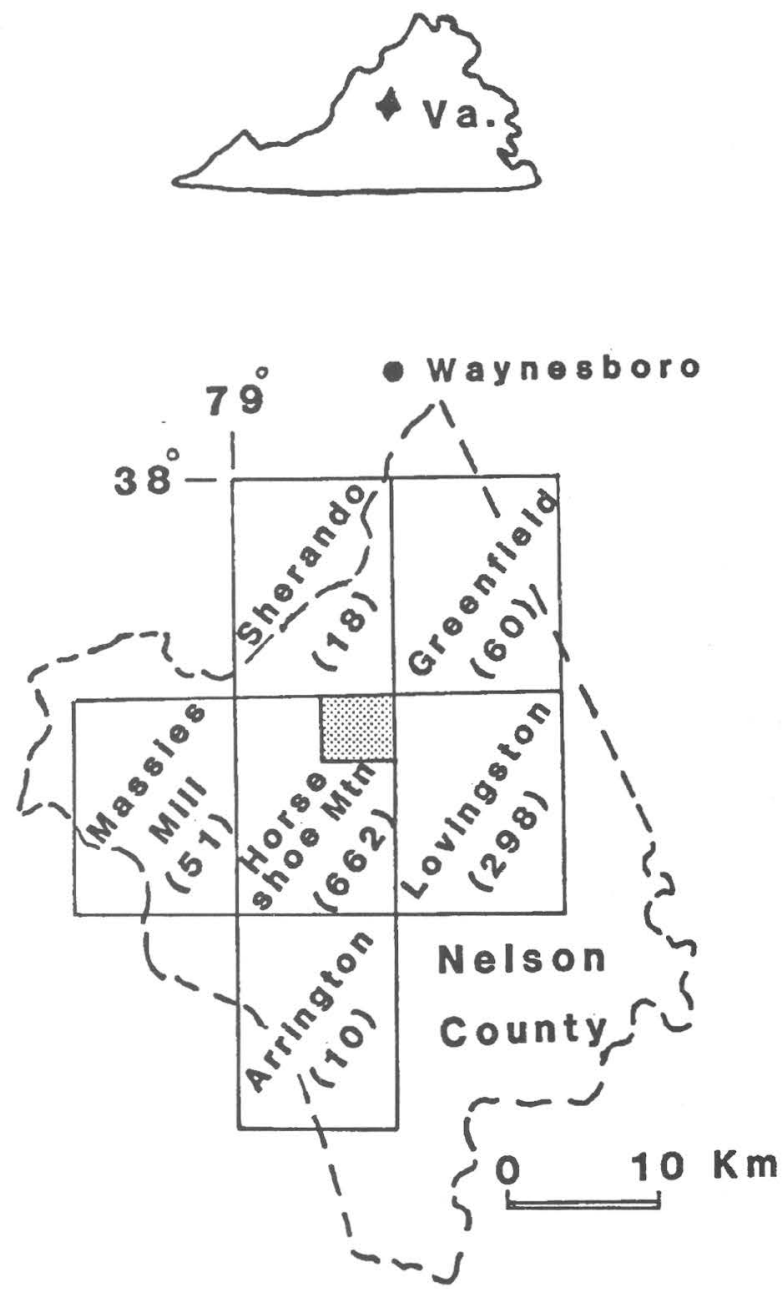

Figure 5.1. Index map of Nelson County, Virginia, showing the 7.5-minute quadrangles contained within the $405 \mathrm{~km}^{2}$ study area. Numbers of debris avalanches related to Hurricane Camille are shown in each quadrangle. Shaded box is index to figure 5.2 .

Gneiss of Sinha and Bartholomew (1984), and the Hills Mountain Granulite Gneiss of Bartholomew and others (1981) are only slightly susceptible. The debris avalanche activity associated with Hurricane Camille predominantly 


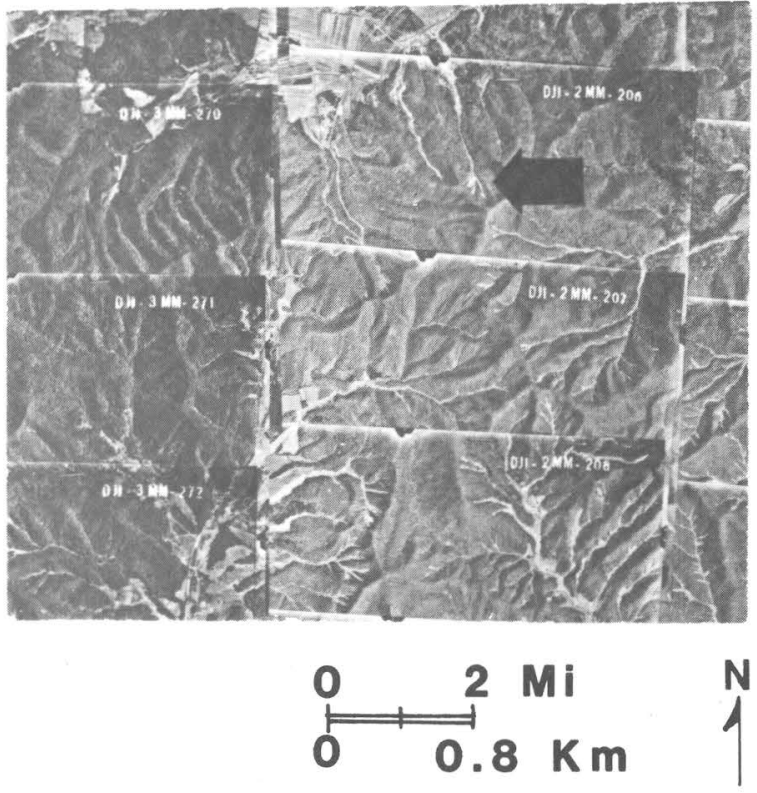

Figure 5.2. Index of 1971 aerial photographs of a portion of the Horseshoe Mountain 7.5-minute quadrangle that was affected by debris avalanches induced by Hurricane Camille in 1969. Arrow refers to avalanche chutes in figure 5.3 that are indicated there by the largest arrow. occurred on northeast-, east-, southeast-, and northwestfacing slopes. Past debris avalanche activity has been documented throughout the central and southern Appalachians (Gryta and Bartholomew, 1983; Hack and Goodlett, 1960; Holmes, 1971; Moneymaker, 1939; Stringfield and Smith, 1956; and U.S. Geological Survey, 1949). During periods of intense rainfall, as associated with Hurricane Camille, future debris avalanche activity is likely to occur not only in central Virginia but also in areas of the Blue Ridge underlain by bedrock similar to that of Nelson County.

\section{REFERENCES CITED}

Bartholomew, M.J., and Lewis, S.W., 1984, Evolution of Grenville massifs in the Blue Ridge geologic province, southern and central Appalachians, in Bartholomew, M.J., ed., The Grenville event in the Appalachians and related topics: Geological Society of America Special Paper 194, p. 229-254.

Bartholomew, M.J., Gathright, T.M., II, and Henika, W.S., 1981, A tectonic model for the Blue Ridge in central Virginia: American Journal of Science, v. 281, no. 9, p. 1164-1183.

Gryta, J.J., and Bartholomew, M.J., 1983, Debris-avalanche type features in Watauga County, North Carolina, in

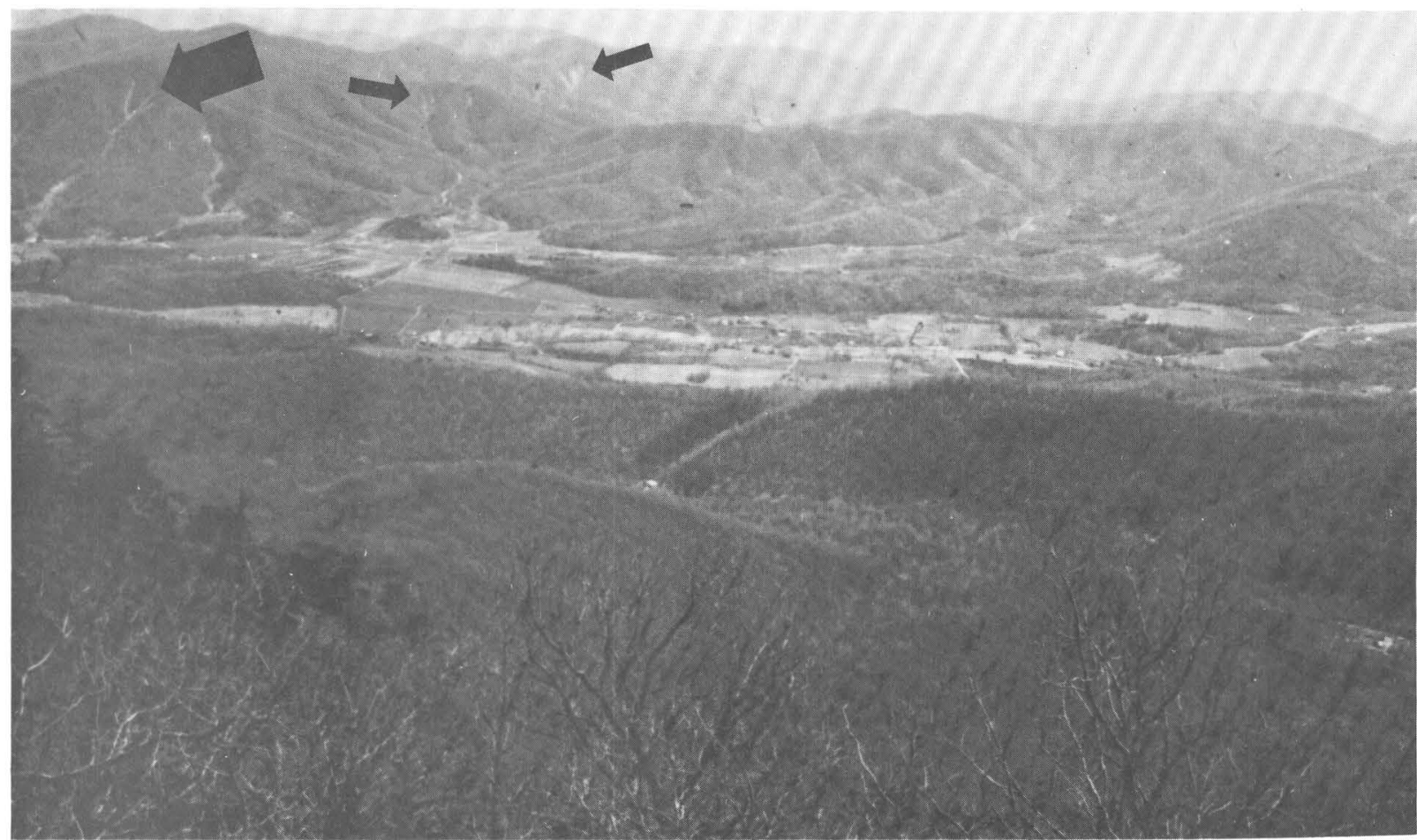

Figure 5.3. The Virginia Blue Ridge as seen from Blackrock Mountain at the Wintergreen recreational area (view is southeastward). Arrows point to debris avalanche chutes scoured along naturally steep slopes during Hurricane Camille in 1969. Large arrow denotes same set of avalanche chutes indicated by arrow in figure 5.2. 
Lewis, S.W. ed., Geological investigations in the Blue Ridge of northwestern North Carolina, Carolina Geological Society Field Trip Guidebook 1983, 10 p.

Hack, J.T., and Goodlett, J.C., 1960, Geomorphology and forest ecology of a mountain region in the central Appalachians: U.S. Geological Survey Professional Paper 347, $66 \mathrm{p}$.

Holmes, J.S., 1971, Some notes on the occurrences of landslides: Journal of the Elisha Mitchell Scientific Society, v. 33 , no. 3, p. $100-105$.

Moneymaker, B.C., 1939, Erosional effects of the Webb Mountain (Tennessee) cloudburst of August 5, 1938: Journal of the Tennessee Academy of Science, v. 14, p. 190-196.

Sinha, A.K., and Bartholomew, M.J., 1984, Evolution of the Grenville terrane in the central Virginia Appalachians, in
Bartholomew, M.J., ed., The Grenville event in the Appalachians and related topics: Geological Society of America Special Paper 194, p. 175-186.

Stringfield, V.T., and Smith, R.C., 1956, Relation of geology to drainage, floods, and landslides in the Petersburg area, West Virginia: West Virginia Geological Survey Water Supply Report on Investigations No. 13, 19 p.

U.S. Geological Survey, 1949, Floods of August 1940 in the Southeastern United States; U.S. Geological Survey Water-Supply Paper 1066, 554 p.

Williams, G.P., and Guy, H.P., 1971, Debris avalanches-a geomorphic hazard, in Coates, D.R., ed., Environmental Geomorphology, 1st Annual Geomorphology Symposia Series, Publications in Geomorphology, Binghamton, State University of New York, p. 25-46.

\section{DEBRIS SLIDES AND DEBRIS FLOWS ON ANAKEESTA RIDGE, GREAT SMOKY MOUNTAINS NATIONAL PARK, TENNESSEE}

\section{G. Michael Clark, ${ }^{1}$ Patrick T. Ryan, Jr., ${ }^{1}$ and Eric C. Drumm ${ }^{2}$}

Five major and four minor avalanche chutes (Ryan and Clark, 1986) are located on Anakeesta Ridge in the Great Smoky Mountains National Park, Tennessee (fig. 6.1). Anakeesta Ridge is an east-west-trending mountain, $4.5 \mathrm{~km}^{2}$ in map area. Summit elevation range is 1,200 to $1,800 \mathrm{~m}$. The ridge is bounded to the north by the second-order, dendritically patterned Alum Cave Creek. To the south is the third-order Walker Camp Prong, closely paralleled by heavily traveled U.S. Highway 441. The underlying Anakeesta Formation includes a variety of rock types (Hadley and Goldsmith, 1963): arkosic pebble conglomerate, graywacke, feldspathic sandstone, chloritoidal slate and argillite, carbonaceous slate, and phyllite. Iron sulfide occurs throughout the rock along bedding and cleavage in the form of pyrite. Along joints, bedding, and cleavage, iron sulfide occurs as limonite and goethite.

In August 1984, a debris slide temporarily closed U.S. Highway 441. There is widespread concern that slides will occur in the future, so there is a need for locational and temporal predictors (Clark, 1984a, b). Useful indicators include morphology, drainage, vegetation, tension cracks in vegetation mat, root throw sites, and geologic structure. Present slide scars are useful in providing failure geometry and sites for estimation of debris volume.

Debris slide analysis involves the application of rock and soil mechanics. Abundant bedding, joint, and

\footnotetext{
${ }^{1}$ Department of Geological Sciences, the University of Tennessee, Knoxville, TN 37996-1410.

${ }^{2}$ Department of Civil Engineering, the University of Tennessee, Knoxville, TN 37996-1410.
}

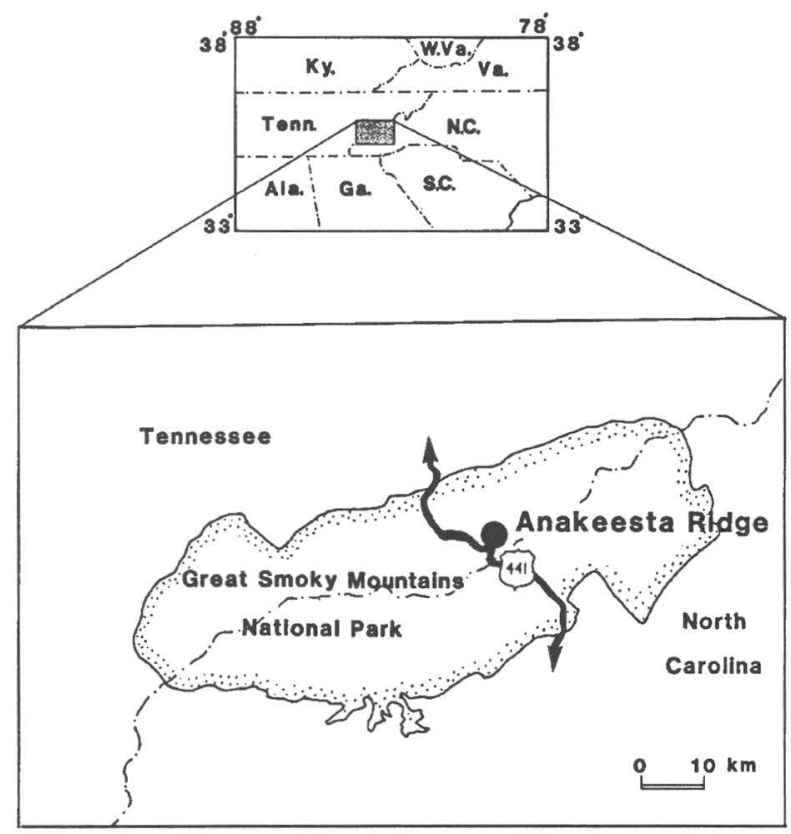

Figure 6.1. Location map showing the Great Smoky Mountains National Park and Anakeesta Ridge.

cleavage discontinuities are available as failure planes and release surfaces along Anakeesta Ridge. Chute morphology along Anakeesta Ridge is characterized by wedge failure planes along the flow track and a combination of circular, planar, and wedge failure planes in the upper slide scar area. Unstable hanging blocks are located in the slide scar. This geometry indicates that limiting-equilibrium analyses may be utilized to assess slope stability. Factors of safety can be determined with 
planar and wedge geometries using the methods of limiting equilibrium outlined by Hoek and Bray (1981). Data required include slope and plane/wedge geometry, internal material friction angle(s), and discontinuity cohesion values. The factor of safety is not greatly influenced over the expected range of internal friction angle (Kane and Drumm, 1986), so determination of discontinuity cohesion is necessary. These values can be computed from the results of direct shear tests involving joint, cleavage, and bedding planes. Use of the STABL slope stability PC program as outlined by Lovell and Thomaz (1986) will enable a variety of failure surfaces to be evaluated.

As the area annually receives 200 to $240 \mathrm{~cm}$ of precipitation (McMaster and Hubbard, 1970), the prime triggering mechanism for debris mobilization may be pore pressure increases following high precipitation (Ryan and Clark, 1986). Such moisture may result from a season of above-normal precipitation or from a single major precipitation event, such as an intense low-pressure cell, a thunderstorm, or a hurricane. Bogucki (1970) noted that intense summer rainstorms are the major cause of debris slides in the Appalachian Highlands. As rain gages in the area are not continuously recording, specific temporal information is lacking.

Scar head and scar flank wastage stations are positioned on the ridge to monitor soil and vegetational mat stability. Backwasting of soil and vegetational mats continues at the scar heads; as of October 1986, the single largest loss has been $12.5 \mathrm{~cm}$ for a $4.3-\mathrm{cm} 2$-day rainfall. Some scar heads have breached the ridge crest; this situation is generally found in association with tree throw. As opposed to continuing scar head wastage, the chute flanks are more stable, as indicated by undisturbed vegetation growth.

In the park, areal extent of the Anakeesta Formation along the Tennessee/North Carolina border is approximately $155 \mathrm{~km}^{2}$. On a regional scale in the Blue Ridge province, the following groups and formations have been mapped on a scale of 1:500,000 as 'sulfidic' slate (North Carolina Geological Survey, 1985): the Great Smoky Group, the Boyd Gap Formation, and the Wehutty Formation. These mapping units represent a large package of pyritiferous rock. If instability on Anakeesta Ridge is related to lithology, then mass movements in as-yet unmonitored areas may be occurring elsewhere within the park, and possibly, also on the regional scale.

\section{REFERENCES CITED}

Bogucki, D.J., 1970, Debris slides and related flood damage associated with the September 1, 1951, cloudburst in the Mt. Leconte-Sugarland Mountain Area, Great Smoky Mountains National Park (Ph.D. thesis): Knoxville, University of Tennessee, $165 \mathrm{p}$.

Clark, G.M., 1984a, Debris slide/debris flow events in Great Smoky Mountains National Park, Tennessee/North Carolina: Processes, site factors, and hillslope development in selected historical events (abs.), in Wood, J.D., Jr., ed., Tenth Annual Scientific Research Meeting, Great Smoky Mountains National Park, May 24-25, 1984, U.S. Department of the Interior, National Park Service, Southeast Regional Office, Atlanta, Georgia, p. 13.

Clark, G.M., 1984b, Debris slide/debris flow events in the Appalachians south of the glacial border: Processes, site factors and hillslope development in selected historical events (abs.): Geological Society of America Abstracts with Programs, v. 16, p. 472.

Hadley, J.B., and Goldsmith, R., 1963, Geology of the eastern Great Smoky Mountains, North Carolina and Tennessee: United States Geological Survey Professional Paper 349-B, p. B1-B118.

Hoek, E., and Bray, J.W., 1981, Rock slope engineering (third edition): London, The Institution of Mining and Metallurgy, $358 \mathrm{p}$.

Kane, W.F., and Drumm, E.C., 1986, Geotechnical factors affecting rock slope stability in eastern Tennessee, in Proceedings, 27th United States Symposium on Rock Mechanics, Tuscaloosa, Alabama, American Institute of Mining Engineers, p. 107-111.

Lovell, C.W., and Thomaz, J.E., 1986, General method for three dimensional slope stability featuring random generation of three dimensional surfaces (abs.), in Proceedings, 37th Annual Highway Geology Symposium, Helena, Montana, p. 7.

McMaster, W.M., and Hubbard, E.F., 1970, Water resources of the Great Smoky Mountains National Park, Tennessee and North Carolina: United States Geological Survey Hydrologic Investigation Atlas HA-420, 2 sheets, scale 1:125,000.

North Carolina Geological Survey, 1985, Geologic map of North Carolina: Department of Natural Resources and Community Development, scale 1:500,000.

Ryan, P.T., and Clark, G.M., 1986, Debris slides on Anakeesta Ride in the GRSM, Tennessee (abs.): Twelfth Annual Scientific Research Meeting, Great Smoky Mountains National Park, May 22-23, 1986, U.S. Department of the Interior, National Park Service, Southeast Regional Office, Atlanta, Georgia, in press. 


\section{BLOCK FIELDS, BLOCK SLOPES, AND BLOCK STREAMS IN THE GREAT SMOKY MOUNTAINS NATIONAL PARK, NORTH CAROLINA AND TENNESSEE}

\section{G. Michael Clark' and C. Allen Torbett III'}

Block-rich diamicton deposits mantle many mountain slopes in the Great Smoky Mountains National Park. Earlier workers (King and others, 1968; Michalek, 1968; and Richter, 1973) attributed certain features to a periglacial origin of Pleistocene age. More recently, Torbett and Clark $(1984,1985,1986)$ have described feature patterns and block fabric orientations similar to those found in forms of known periglacial origin in present-day cold climates. This paper describes selected block deposits in the park (fig. 7.1) and the related ongoing research.

Block fields, block slopes, and block streams (White, 1976) occur on and downslope from metaquartzite bedrock sources that are predominantly from the Thunderhead Sandstone in the park. Block fields display no longer dimension evident in plan view; they range from a few tens to hundreds of meters across. Block slopes are contiguous rock fragment accumulations that are elongate parallel to contour orientations and frequently grade upslope into talus. Block streams are elongate in the slope direction; their lengths range from a few tens to over 1,000 meters across. All three forms grade laterally into other types of colluvial and alluvial soils; they grade upslope into talus. Bedrock lithologic variations, structure, slope, slope aspect, and processes of block production, transport, and emplacement are the most evident localizing factors at most sites. Features extend downslope from bedrock sources to elevations as low as $670 \mathrm{~m}$. Hillslope angles of ten deposits surveyed range from $10^{\circ}$ to $34^{\circ}$ and average $20^{\circ}$. Bordering soils are chiefly Lithic Dystrochrepts and Typic Umbrepts, and all sites are forested.

Research techniques used to describe and characterize block deposits are block fabric analysis (Caine, 1968; Nelson, 1982), soil characterization analyses of underlying and bordering soils, large-scale mapping and profiling, and the extraction of sediment samples for ${ }^{14} \mathrm{C}$ and thermoluminescence age dating. Field evidence of slope stability includes pronounced differential weathering on blocks, undisturbed forest cover, disintegrated in-place block fragments, and undeformed forest soil horizons.

Support for a paleoperiglacial hypothesis to explain block deposit origins comes from independent lines of evidence. Palynological studies of high-elevation organic deposits demonstrate that mountain elevations were above the forest limit during late glacial cold phase maxima (Delcourt and Delcourt, 1981). Block fabric

\footnotetext{
${ }^{1}$ Department of Geological Sciences, The University of Tennessee, Knoxville, TN 37996-1410.
}

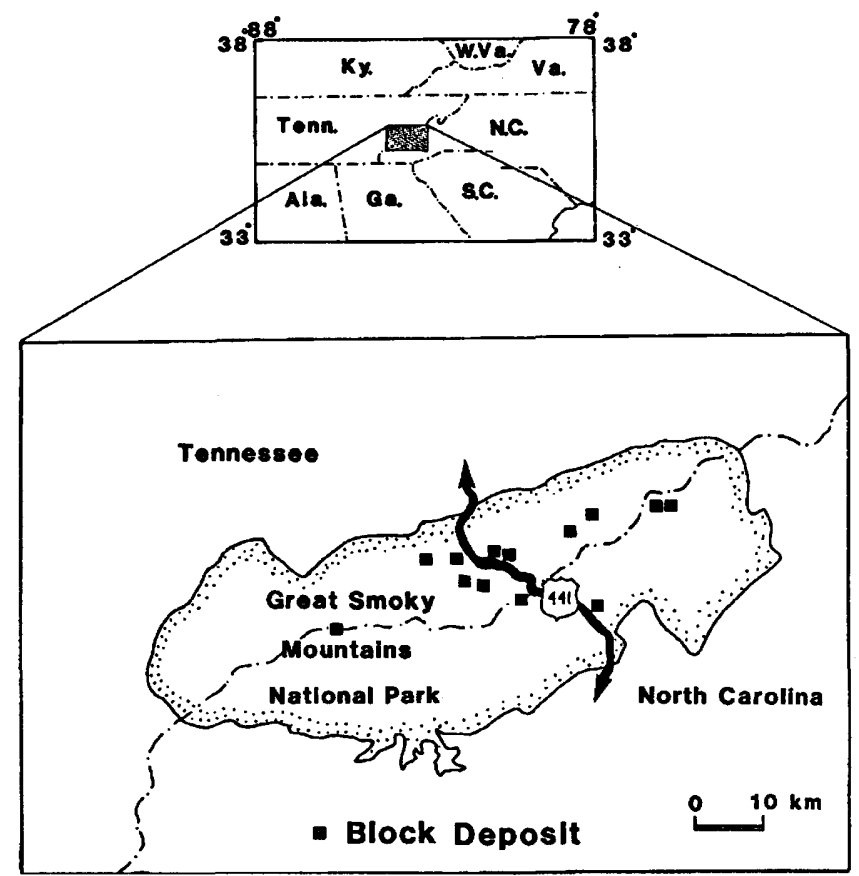

Figure 7.1. Location map of the Great Smoky Mountains National Park showing block deposits (undifferentiated) described in text.

analysis yields orientation data consistent with values obtained from active cold-climate features (Nelson, 1982). Forthcoming absolute age dates will provide a chronology that will relate these deposits to similar features elsewhere within the Appalachian Highlands and will shed additional light on their origin.

A clear understanding of genesis and age of block deposits is critical to Appalachian geomorphology. Large areas of mountain slope are veneered with these deposits, and they grade laterally into many other types of unconsolidated hillslope and flood plain sediments. Therefore, they are responsible for shaping topographic form, and they grade laterally into other materials which also uphold landforms. Except in areas underlain by bedrock outcrops, knowledge of the timing and nature of regolith genesis, mobilization, and emplacement is therefore critical to explanation of the morphology of unglaciated Appalachian Mountain landscapes.

\section{REFERENCES CITED}

Caine, N., 1968, The fabric of periglacial blockfield material on Mt. Barrow, Tasmania: Geografiska Annaler, v. 50A, p. 193-206. 
Delcourt, P.A., and Delcourt, H.R., 1981, Vegetation maps for eastern North America: 40,000 yr B.P., to the present, in Romans, R., ed., Geobotany II: New York, Plenum Press, p. 123-166.

King, P.B., Neuman, R.B., and Hadley, J.B., 1968, Geology of the Great Smoky Mountains National Park, Tennessee and North Carolina: United States Geological Survey Professional Paper 587, 23 p.

Michalek, D.D., 1968, Fanlike features and related periglacial phenomena of the southern Blue Ridge (Ph.D. thesis): Chapel Hill, North Carolina, University of North Carolina, $198 \mathrm{p}$.

Nelson, F., 1982, Sorted stripe macrofabrics: Geografiska Annaler, v. 64A, p. 25-33.

Richter, D.M., 1973, Periglacial features in the central Great Smoky Mountains (Ph.D. thesis): Athens, Georgia, University of Georgia, $148 \mathrm{p}$.

Torbett, C.A., III, and Clark, G.M., 1984, Sorted patterned ground: new locality in the Appalachians, Great Smoky
Mountains National Park, North Carolina/Tennessee (abs.), in Wood, J.D., Jr., ed., Tenth Annual Scientific Research Meeting, Great Smoky Mountains National Park, May 24-25, 1984: U.S. Department of the Interior, National Park Service, Southeast Regional Office, Atlanta, Georgia, p. 11-12.

- - 1985 , Morphology, pedology, and origin of selected sorted patterned ground, Great Smoky Mountains National Park, Tennessee/North Carolina (abs.): Geological Society of America Abstracts with Programs, v. 17:2, p. 139.

- - - 1986, Sorted patterned ground in the GRSM, North Carolina/Tennessee (abs.): Twelfth Annual Scientific Research Meeting, Great Smoky Mountains National Park, May 22-23, 1986: U.S. Department of the Interior, National Park Service, Southeast Regional Office, Atlanta, Georgia, in press.

White, S.E., 1976, Rock glaciers and block fields, review and new data: Quaternary Research, v. 6, p. 77-97.

\section{COLLUVIAL DIAMICTONS IN THE VALLEY AND RIDGE PROVINCE, WEST VIRGINIA AND VIRGINIA}

\section{J. Steven Kite ${ }^{1}$}

A variety of colluvial deposits occurs in fans and aprons adjacent to steep slopes in the Valley and Ridge physiographic province. Many of these deposits are well exposed because of scour during flooding throughout the region during November 1985. These new exposures allow a stratigraphic approach to the study of colluvial deposits, without the effort and expense of excavation. Although many of the newly exposed colluvial deposits are composed of only one type of sediment, many colluvial landforms with simple surface expression are underlain by very complex stratigraphies.

Most of the colluvial deposits are diamictons, nonsorted or very poorly sorted sediments with a wide range of grain sizes. Diamictons are further characterized by the abundance of the coarsest clasts in the sediment. In the following discussion, pebble diamicton refers to sediment ranging from clay to pebble but lacking substantial cobble or boulder fractions. Cobble-sized clasts are the dominant sediment in cobble-boulder diamictons, although boulders are common. Boulder-cobble diamictons include roughly equal amounts of boulders and cobbles.

Much of the variability of colluvial diamictons can be attributed to differences in bedrock lithologies exposed on adjacent slopes. Many bedrock units break down into characteristic clast sizes and shapes. For

\footnotetext{
1 Department of Geology and Geography, West Virginia University, Morgantown, WV 26506.
}

example, sandstones of the Tuscarora Formation, Massanutten Sandstone, and Pottsville Formation yield large blocky boulders. By contrast, Devonian cherts produce very angular cobbles and large pebbles. In general, colluvial deposits will be dominated by the particle sizes and shapes that are the common breakdown products of bedrock occurring up adjacent slopes.

In spite of the influence of local bedrock lithologies, the complexities of many colluvial exposures indicate that different processes have dominated nearby slopes at different times. It is too early to determine the exact causes of this variability in colluvial deposits, but late Cenozoic climatic fluctuations and catastrophic rainfall events may have been important factors.

One of the most striking attributes of colluvium throughout the central Appalachians is that many deposits are capped by a concentration of large boulders. This observation is particularly true for colluvial aprons. Many deposits with an outward appearance of clast-supported talus actually have an abundant fine-grained matrix when exposed. Some deposits have boulders at the surface that are larger than the coarsest clast found within the remainder of the deposit. A number of hypotheses have been offered to explain the coarse clasts at the top of colluvial deposits. These include inverse-grading during a single colluvial event, a late episode of boulder deposition, the cumulative effects of frost action during and after colluviation, postcolluvial winnowing at the surface, or postcolluvial sieve deposition in the voids of a clast-support framework. It is likely that each hypothesis has a given locality at which it is correct. 


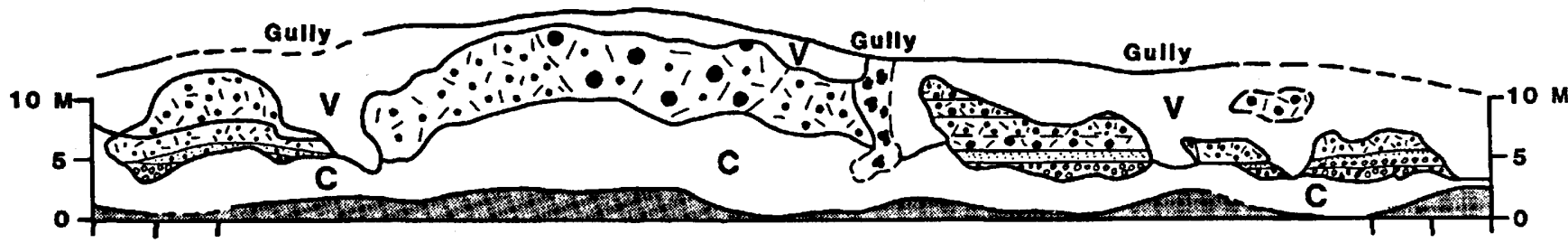

EXPLANATION
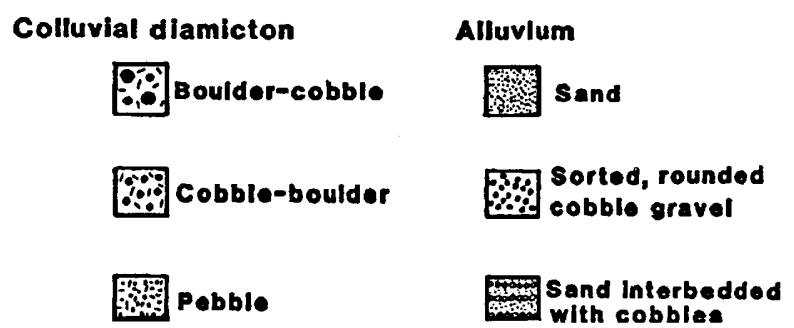

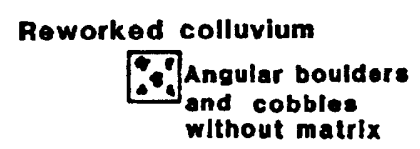

Alluvium and colluvium(?)

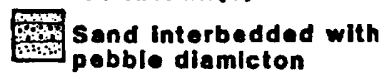

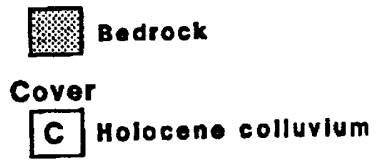

V Vegetation

Figure 8.1. Stratigraphic cross section of a Quaternary colluvial fan-alluvial terrace complex near Cabins, West Virginia. Top line represents the fan surface; bottom line represents the water level of the North Fork South Branch Potomac River on September 26, 1986. No vertical exaggeration.

Multiple diamictons, similar to the "two-till" exposures of New England, are exposed at several locations in colluvial aprons throughout the Valley and Ridge province of the Virginias. A typical sequence is a thick $(2-5 \mathrm{~m})$ cobble-boulder diamicton overlying a thick $(>3 \mathrm{~m})$ pebble diamicton. Both have strong down-slope clast fabrics and the contact between the two units is abrupt. Buried paleosols are common, both along the contact and within the upper unit. This suggests periods of slope stability between episodes of colluviation.

An exposure on the North Fork South Branch Potomac River near Cabins, West Virginia (fig. 8.1), shows the variety of deposits within colluvial-alluvial fans in the region. The fan is located approximately $1 \mathrm{~km}$ west of North Fork Gap (Hopeville 7.5-minute quadrangle) and occurs at the mouth of a second-order drainage basin with over $600 \mathrm{~m}$ of relief. Bedrock within the basin includes the Tuscarora Sandstone, Juniata Formation, and Oswego Sandstone (Cardwell and others, 1968). The fan has been mapped as part of a large debris flow during a major storm in 1949 (Felton, 1978; Stringfield and Smith, 1956), an observation recently confirmed by local residents.

A cursory examination of the outcrop reveals a simple stratigraphy of three unconsolidated units above the Oswego Sandstone bedrock, $1.5 \mathrm{~m}$ of alluvial cobble gravel overlain by $1 \mathrm{~m}$ of inverse-graded alluvial sand and silt, which is overlain by as much as $10 \mathrm{~m}$ of colluvial diamicton. Detailed work at the exposure shows that the outcrop is actually much more complex than a single three-fold stratigraphy. Although no tree-ring studies have been conducted, it is clear that only the central portion of the fan is devoid of large trees that probably predate the 1949 debris flow. Evidently, parts of the fan surface stabilized prior to 1949 , so the colluvial deposits beneath these surfaces must have formed during an earlier event, or earlier events. The alluvial gravel is too poorly exposed to allow definite correlation, but the sandy alluvium may not be relict from a single flood plain surface. The sandy alluvium occurs at slightly different elevations, is dissimilar from one part of the outcrop to another, and is overlain by at least two different types of colluvial diamicton at different parts of the outcrop. It is possible that the sandy alluvium was deposited at nearly the same level on different-aged flood plain surfaces that were buried by different colluvial events. Although minor amounts of organic matter occur in the sandy alluvium, the quantity sampled has been insufficient for conventional radiocarbon dating.

The colluvial units overlying the sandy alluvium are quite varied. The central part of the fan is underlain by at least $8 \mathrm{~m}$ of unstratified, boulder-cobble diamicton, the coarsest sediment in the exposure. There is no apparent change in particle size throughout this unit, except for a few pods of clast-supported cobbles and lenses of cobbleboulder diamicton. Boulders of white Tuscarora Sandstone are most abundant in this unit, although most of the 
clasts are red Juniata Sandstone. The boundary with the adjacent cobble-boulder diamicton unit is very subtle, although it coincides with a small ridge (debris-flow levee?) at the break in tree size on the surface. Accordingly, the boulder-cobble diamicton at the center of the exposure was probably deposited by the 1949 debris flow.

Cobble-boulder diamicton occurs at four or more sites on the exposure. It is the uppermost sediment exposed on either side of the fan and is adjacent to, and somewhat overlapped by, the boulder-cobble diamicton. In places the cobble-boulder diamicton may be very poorly stratified. The overlying surfaces support relatively old trees. As in the coarser diamicton, there is no obvious change in particle size throughout the unit. The origin of this sediment is unclear, but its gross similarity with the probable historic debris flow suggests that the cobbleboulder diamicton at this locality formed either during several debris flows or during pulses in a single debris flow. The overall finer grain size suggests these events may have had less energy than the 1949 debris flow.

Pebble diamicton is exposed above the alluvium on either side of the fan. It commonly is weakly stratified and contains very few clasts of white Tuscarora Sandstone. Pebble diamicton is very common in colluvial aprons in the area and may represent local slope colluvium, possibly delivered to the site by creep or debris slide.

A sequence of three relatively thin ( 1 to $3 \mathrm{~m}$ ) normally graded diamicton beds occurs just west of the center of the fan. Cobble-boulder or cobble diamictons are the basal sediments in these packages, which fine upward to pebble diamicton. A few centimeters of sand cap two of these graded beds. As in other exposures in the region, these normally graded packages occur as repetitive sequences that become thinner and finer grained up sequence. The origin of this sequence is unknown, but the poor sorting and graded bedding suggest pulses of hyperconcentrated flow, possibly at the distal end of small debris flows.
Small steep-sided lenses of angular boulder-cobble gravel occur at the distal ends of gullies eroded into the fan, apparently because of post-colluvial reworking by overland flow or stream flow in small drainage ways. These lenses are relatively minor in the exposure near Cabins, West Virginia, but many other fans exposed in the region are composed mostly of similar sediment. Indeed, the frequency of debris flow and other colluvial events in the region may be difficult to assess because stream flow quickly winnows away the matrix from the diamictons and destroys the primary colluvial landforms and sedimentary structures.

A great variety of colluvial diamictons occur in the Valley and Ridge province of West Virginia, especially in colluvial-alluvial fans, such as the one exposed near Cabins. Although excavation will remain an important tool in the study of colluvium in most settings, there is an urgent need to document the stratigraphy of the many outcrops exposed during the flooding of November 1985. Such a stratigraphic approach to the study of colluvium should provide data pertinent to issues upon which we have speculated for years. Indeed, we may never get a better opportunity to see so many of these deposits exposed.

\section{REFERENCES CITED}

Cardwell, D.H., Erwin, R.B., and Woodward, H.P., 1968, Geologic map of West Virginia: West Virginia Geological and Economic Survey, 1:250,000 scale.

Felton, L.C., Jr., 1978, Mass movement in the Smoke Hole region, Valley and Ridge Physiographic Province, West Virginia (M.S. thesis): Morgantown, West Virginia, West Virginia University, $56 \mathrm{p}$.

Stringfield, V.T., and Smith, R.C., 1956, Relation of geology to drainage, floods, and landslides in the Petersburg area, West Virginia: West Virginia Geological Survey and Economic Survey Report of Investigations No. 13, 19 p. 


\title{
9. PREHISTORIC GIANT ROCKSLIDES OF THE APPALACHIAN VALLEY AND RIDGE PROVINCE: TYPES AND CHARACTERISTICS
}

\author{
C. Scott Southworth
}

\section{INTRODUCTION}

Four different types of prehistoric giant rockslides have been recognized in the Appalachian Valley and Ridge province as a result of field mapping and photogeologic analysis: rock slumps, rock block slides, rock avalanches, and debris avalanches, all dip-slope failures on anticlinal fold limbs. The rockslides involve predominantly sandstone and quartzite, with the detachment plane located near a basal shale and (or) limestone contact. Individual rockslides have dimensions as large as $2.5 \mathrm{~km}$ by $4.3 \mathrm{~km}$, although rockslide complexes as long as $96 \mathrm{~km}$ have been recognized. Approximate volumes of rockslide material range from 3 million to 1 billion cubic meters. The displaced masses have undergone extensive erosion and may only be remnants of what were previously much more extensive rockslides. Various stages of rock failure and different degrees of weathering suggest that the rockslide process has been active for an extended period of time. Although several rockslides still have active parts, most are relict features. The relationship of rockslides to fluvial terraces and the preexisting colluvial mantle suggests formation during, if not before, the Pleistocene Epoch.

Geomorphic characteristics of the rockslides include steep head scarps and lateral scarps that occur along joint planes, bedding plane dip reversals and topographic slope reversals, karstlike topography with springs, swamps, and sag ponds, subparallel topographic benches intervening with elliptical depressions, and large fissures in bedrock.

Several rockslides may have been triggered by paleofluvial cut-bank erosional processes. Additional triggering mechanisms for the rockslides include fluctuations in periglacial climate and seismic shaking. Gravity failures of this magnitude suggests extreme erosive, climatic, and perhaps paleoseismic conditions as key elements in their formation. The identification of prehistoric giant rockslides represents a newly recognized geomorphic process in the Appalachian Valley and Ridge province.

\section{BACKGROUND}

The recognition of prehistoric giant rockslides in the Appalachian Valley and Ridge province is relatively new (Schultz, 1985; 1986). Schultz (1986) identified a zone of rock block slides through recognition of anomalous topography and discordant stratigraphy during geologic mapping of Sinking Creek Mountain, Virginia. Subsequent photogeologic analysis and field mapping identified more than 15 rockslides that could be classified into 4 general types: rock slumps, rock block slides, rock avalanches, and debris avalanches (Southworth and Schultz, 1986). Slope failures analogous to ancient giant Appalachian rockslides have also been identified in the Rocky Mountains (Mudge, 1965; Cruden, 1976; Braddock, 1978) and Zagros Mountains (Watson and Wright, 1967).

The classification of types of giant Appalachian rockslides is modified after Varnes' (1978) and Mollard and Jane's (1984) classification of landslides. Only remnants of the rockslides are preserved because of extensive post-emplacement erosion, so description and classification of the four types of rockslides are warranted.

\section{ROCKSLIDE TYPES}

The distinction of the four types of rockslides in the Appalachian Valley and Ridge province is based on the form, relative rate and amount of movement, character of the detachment surface, and character of the deposit (tables 9.1 and 9.2), all of which have been derived from detailed field observation of the rockslides indexed in figure 9.1. Rock slumps consist of a combination of rock block slides and rock falls whose present character consists of a jumbled mass of rock proximal to a head scarp. Morphological characteristics of rock slumps are similar to those of rock block slides (table 9.1); a distinction is that rock slumps involve multiple rock blocks of smaller dimension. Rock slumps may represent either in-situ disintegration of large rock block slides or they may represent a mature stage of downslope transport (see Schultz, paper 10). Field characteristics include chaotic boulders and blocks strewn among ridge and swale topography downslope from a vertical rock cliff. In contrast, rock block slides consist of single- or multiple-allochthonous rock blocks that have been transported downslope with varying degrees of horizontal and (or) vertical rotation. Field characteristics include anomalous bedding and slope reversals, isolated knobs with a nearly flat surface, and disrupted drainage.

Rock avalanches are massive colluvial deposits consisting primarily of fragmented rock proximal to a topographically high source. They can be a complex of rockfall, rock topple, and rockslide, which are chaotically distributed as a lobate fan often covering a large area. Field characteristics include gently sloping topography mantled with sandstone or quartzite colluvium near a topographically high outcrop. In contrast, debris avalanches consist of an unsorted mixture of rock, soil, and vegetation; they are considered to be the result of rapid 


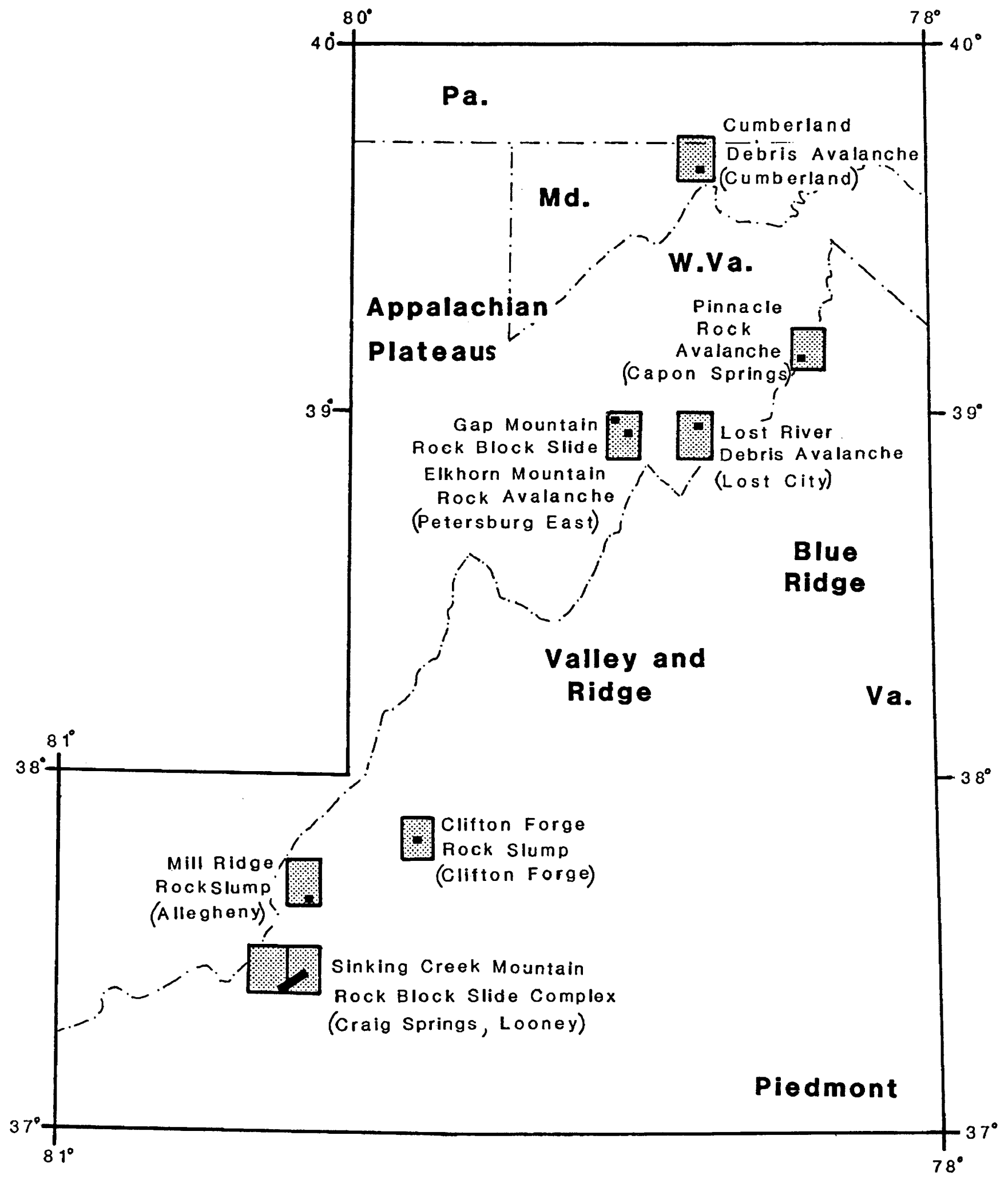

Figure 9.1. Index map to prehistoric giant rockslides in the Appalachian Valley and Ridge province. Rockslides are indexed to USGS 7.5-minute quadrangle maps in parentheses. See table 9.2 for detailed descriptions. 
Table 9.1. Characteristics of the four primary types of giant rockslides in the Appalachian Valley and Ridge province

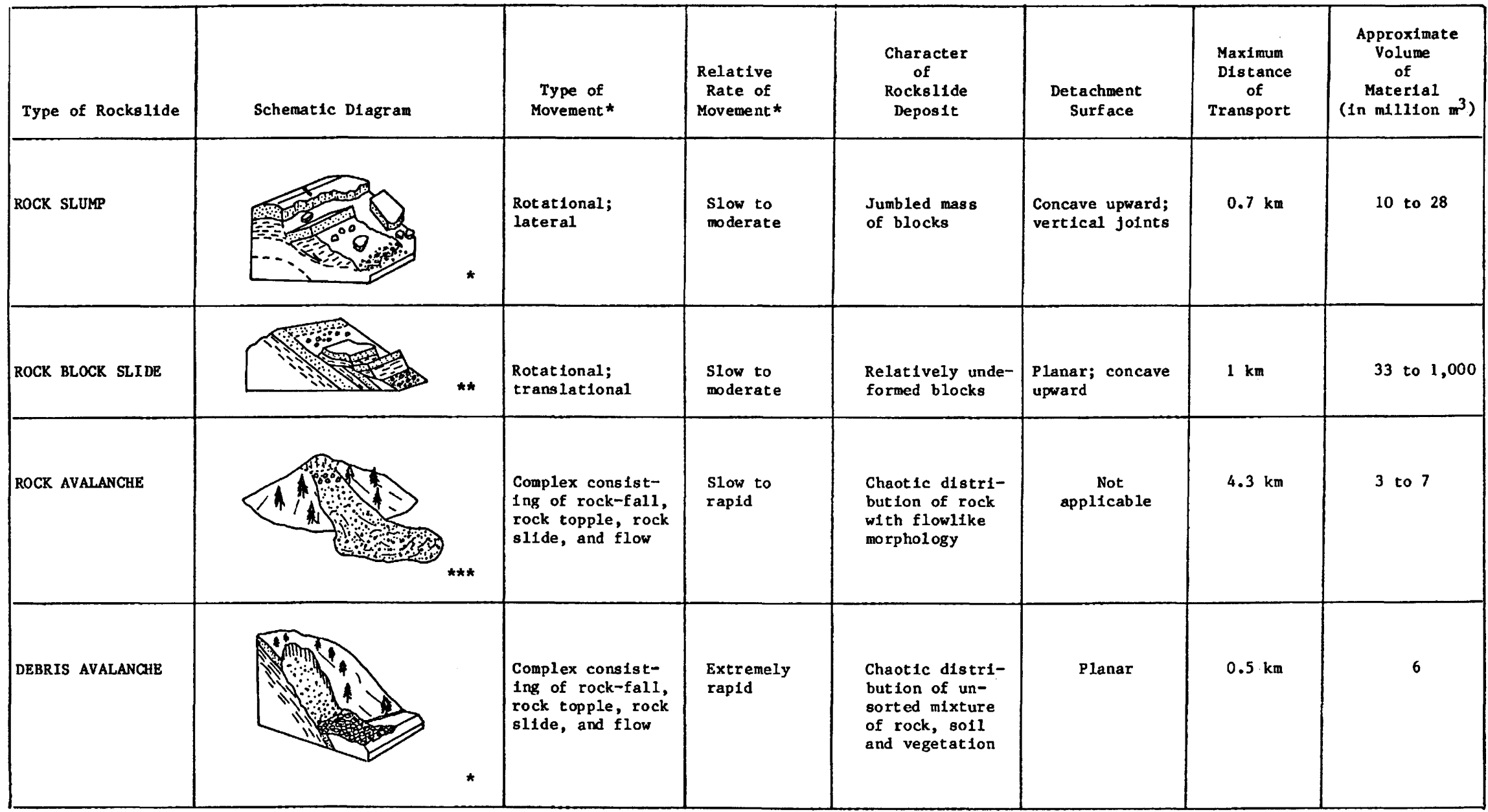

* Modified after Varnes, 1978

*** Modified after Mollard and Janes, 1984. 
Table 9.2. Characteristics of named prehistoric giant rock slumps, rock avalanches, debris avalanches, and rock block slides in the Appalachian Valley and Ridge province

\begin{tabular}{|c|c|c|c|c|c|c|c|c|c|c|c|}
\hline $\begin{array}{l}\text { Rocks11de } \\
\text { Type }\end{array}$ & $\begin{array}{l}\text { Name of } \\
\text { Peature }\end{array}$ & $\begin{array}{l}7.5-m 1 \text { nute } \\
\text { Quad }(s)\end{array}$ & Structural setting & $\begin{array}{l}\text { Lithologies } \\
\text { nnvolved in the } \\
\text { Rocks11de }\end{array}$ & $\begin{array}{l}\text { Position of } \\
\text { Head Scarp }\end{array}$ & $\begin{array}{c}\text { Ge omorphic } \\
\text { Features }\end{array}$ & $\begin{array}{l}\text { Topographic } \\
\text { Relief Fron } \\
\text { Head to Toe }\end{array}$ & $\begin{array}{r}\begin{array}{r}\text { Rocks } \\
\text { Dimens }\end{array} \\
\text { Length } \\
\text { NH-SE }\end{array}$ & \begin{tabular}{|l|}
11 ide \\
11ons \\
Width \\
NE-SW
\end{tabular} & $\begin{array}{l}\text { Yolune of } \\
\text { Rocks1lde }\end{array}$ & Remarks \\
\hline $\begin{array}{l}\text { ROCK } \\
\text { SLUMP }\end{array}$ & $\begin{array}{l}\text { C11fton } \\
\text { Porge }\end{array}$ & $\begin{array}{l}\text { Clifton Forge, } \\
\text { Va. }\end{array}$ & 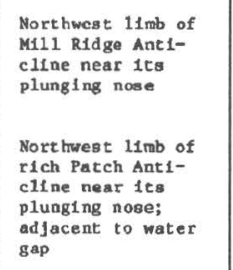 & 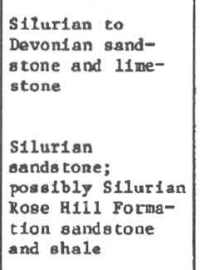 & $\begin{array}{l}\text { Axt al trece of } \\
\text { overturned } \\
\text { ant 1c11ne down- } \\
\text { slope from crest } \\
\text { of mountain } \\
\text { Crest of ant1- } \\
\text { cline }\end{array}$ & $\begin{array}{l}\text { Hoad sca rps, } \\
\text { leteral scarps, } \\
\text { flssures, topo- } \\
\text { graphic benches } \\
\text { and furrows } \\
\text { Head scarp, } \\
\text { 1soloted giant } \\
\text { blocks, topo- } \\
\text { graphic benches, } \\
\text { and block } \\
\text { fields }\end{array}$ & $244 \mathrm{~m}$ & $1.6 \mathrm{~km}$ & $0.8 \mathrm{~km}$ & $10 \times 10^{6} \mathrm{~m}^{3}$ & $\begin{array}{l}\text { Adjacent to MIII Creek; detachment } \\
\text { at or near sands tone and limestone } \\
\text { contact } \\
\text { Possible peleof luvial cut-benk } \\
\text { origin; detachnent at or near sand- } \\
\text { s tone or shale contact }\end{array}$ \\
\hline $\begin{array}{l}\text { ROCK } \\
\text { BLOCX } \\
\text { SLIDE }\end{array}$ & $\begin{array}{l}\text { Sinking } \\
\text { Creek Moun- } \\
\text { taln }\end{array}$ & $\begin{array}{l}\text { Newport, } \\
\text { Craig Springs, } \\
\text { Looney, and } \\
\text { McDonald's } \\
\text { M111, Va. }\end{array}$ & 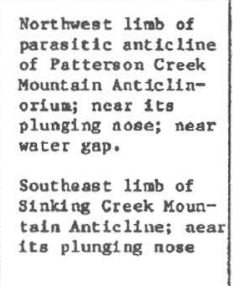 & $\begin{array}{l}\text { Devonian sand- } \\
\text { stone and Devon- } \\
\text { 1an l1mes tone } \\
\text { S1lurian sand- } \\
\text { stone and sand- } \\
\text { stone and ahale }\end{array}$ & $\begin{array}{l} \\
\text { Southeast } \\
\text { flank of } \\
\text { suticline }\end{array}$ & $\begin{array}{l}\text { Head scarp, } \\
\text { lateral scarps, } \\
\text { sag reg1 on with } \\
\text { swamps, and } \\
\text { topographic } \\
\text { reversal } \\
\text { Topographic } \\
\text { and d1p rever- } \\
\text { sals, sag ponds } \\
\text { and lateral } \\
\text { scarps }\end{array}$ & $\begin{array}{l}305 \text { to } \\
610 \mathrm{~m}\end{array}$ & $0.5 \mathrm{~km}$ & $2.5 \mathrm{~km}$ & $\begin{array}{l}\text { At leagt } \\
100 \times 10^{2} \mathrm{~m}^{3}\end{array}$ & 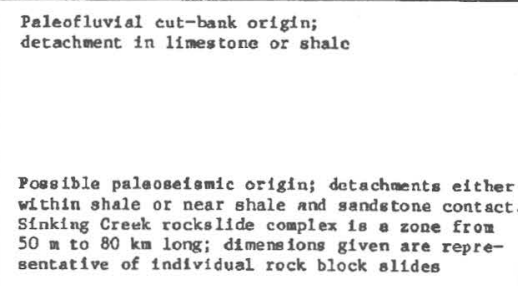 \\
\hline $\begin{array}{c}\text { ROCK } \\
\text { AVALANCKE }\end{array}$ & $\begin{array}{l}\text { E1khorn } \\
\text { Mounta1a }\end{array}$ & $\begin{array}{l}\text { Capon Springs, } \\
\text { Va./W.Va. }\end{array}$ & 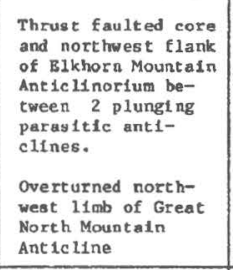 & $\begin{array}{l}\text { Silurian quart- } \\
\text { zite; some } \\
\text { Devondan sand- } \\
\text { stone } \\
\text { Ordovician } \\
\text { through Devonian } \\
\text { clastlc rocks }\end{array}$ & $\begin{array}{l}\text { Crest and west } \\
\text { slope of moun- } \\
\text { tain }\end{array}$ & $\begin{array}{l}\text { Head scarp, } \\
\text { rock cit tes, } \\
\text { tongue-shaped } \\
\text { lobate deposit }\end{array}$ & $457 \mathrm{~m}$ & $2.8 \mathrm{~km}$ & $2.5 \mathrm{~km}$ & $\operatorname{Min}_{3 \times 10^{6}} 0^{\circ} \mathrm{m}^{3}$ & 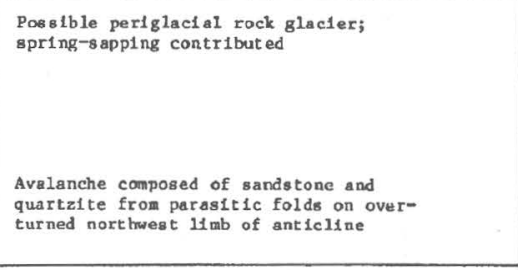 \\
\hline $\begin{array}{l}\text { DEBRIS } \\
\text { AVALANCHE }\end{array}$ & Cumberland & $\begin{array}{l}\text { Cumberland, } \\
\text { Md., W.Va., }\end{array}$ & $\begin{array}{l}\text { Northwest limb } \\
\text { Hanging Rock Ant1- } \\
\text { cline near 1ts } \\
\text { southern terminus; } \\
\text { near water gap with } \\
\text { cross-strike struc- } \\
\text { tural movement } \\
\text { Overturned nortimest } \\
\text { limb of wills Moun- } \\
\text { tain Ant ic line; } \\
\text { adfacent to water } \\
\text { gap }\end{array}$ & $\begin{array}{l}\text { Ordovician gand- } \\
\text { stone and shale } \\
\text { and S1lurian } \\
\text { quartzite }\end{array}$ & $\begin{array}{l}\text { Crest of moun- } \\
\text { taln (southeast } \\
\text { flank) }\end{array}$ & $\begin{array}{l}\text { Act1ve debris } \\
\text { chutes, heed } \\
\text { scarp, lateral } \\
\text { scarp, exten- } \\
\text { sive block } \\
\text { streans and } \\
\text { rock block } \\
\text { slides }\end{array}$ & $305 \mathrm{~m}$ & $0.6 \mathrm{~km}$ & $1.0 \mathrm{~km}$ & $\begin{array}{l}\text { Mass } \\
\text { removed by } \\
\text { subsequent } \\
\text { erosion }\end{array}$ & $\begin{array}{l}\text { Paleofluvial cut-bank origin; detach- } \\
\text { ment at or near sandstone and } \\
\text { If mes tone contact }\end{array}$ \\
\hline
\end{tabular}



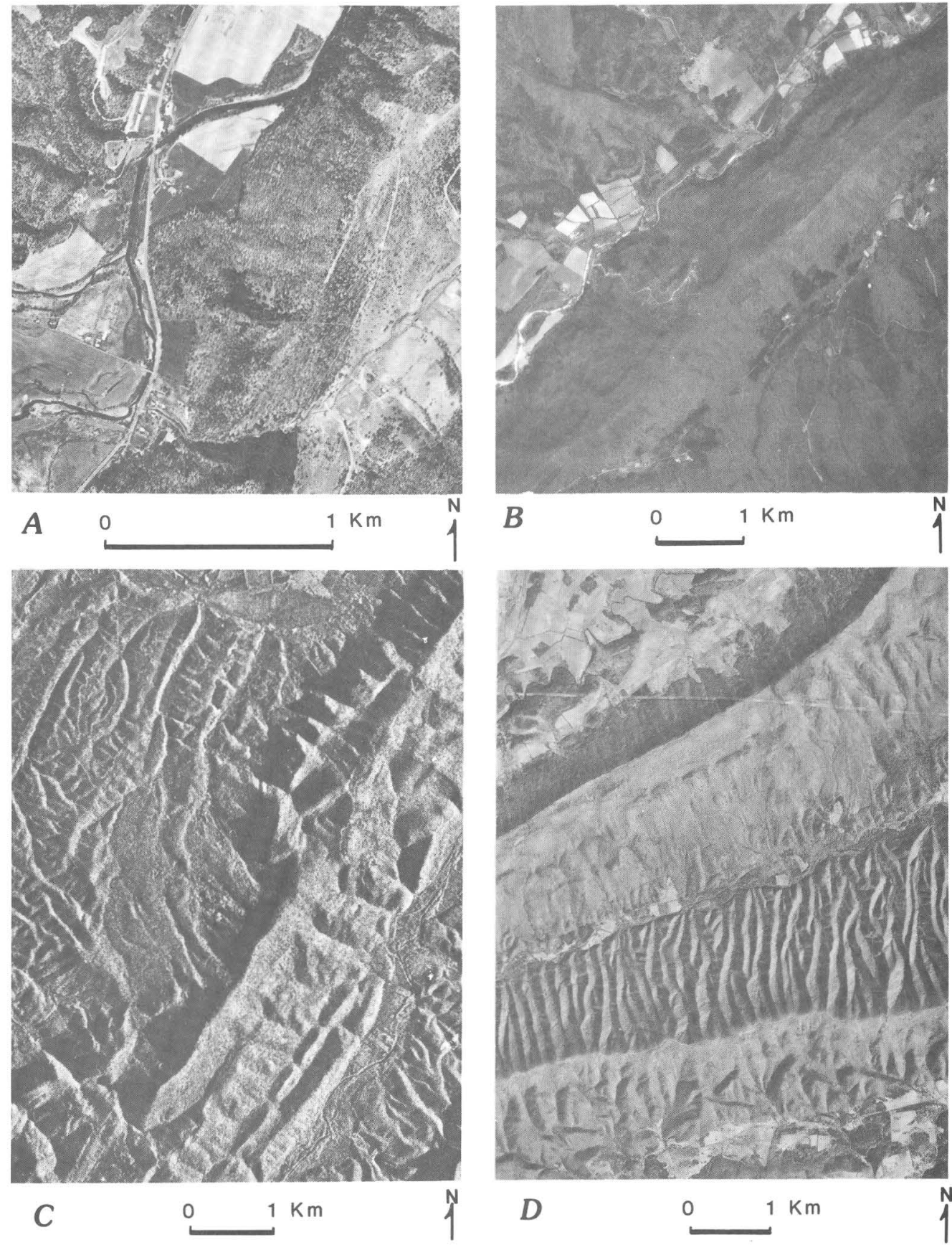

Figure 9.2. $A$, Medium-altitude vertical aerial photograph of the Lost River (West Virginia) debris avalanche $\left(38^{\circ} 57^{\prime} 30^{\prime \prime} \mathrm{N} ., 7^{\circ} 48^{\prime} \mathrm{W}\right.$.) (USGS NHAP 83 513-104, acquired April 11, 1984). B, Mediumaltitude vertical aerial photograph of the Mill Ridge (Virginia/West Virginia) rock slump $\left(37^{\circ} 39^{\prime} 33^{\prime \prime} \mathrm{N}\right.$., $80^{\circ} 8^{\prime}$ W.) (USGS NHAP 80 458-146, acquired April 23, 1982). C, Side-looking airborne radar (SLAR) image of Elkhorn Mountain (West Virginia) rock avalanche (38 $57^{\prime} \mathrm{N}$., $79^{\circ} 2^{\prime} 30^{\prime \prime} \mathrm{W}$.) (USGS SLAR CAPA 9-70 near-range, acquired September 15, 1982). D, Medium-altitude vertical aerial photograph of a portion of the Sinking Creek Mountain (Virginia) rock block slide complex $\left(37^{\circ} 20^{\prime} \mathrm{N}\right.$., $80^{\circ} 21^{\prime} \mathrm{W}$.) (USGS NHAP 80 589-8, acquired April 1, 1982). All data available from the EROS Data Center, Sioux Falls, South Dakota. Approximate scene centers given.

Figure 9.3. Generalized geologic maps of the $(A)$ Lost River (West Virginia) debris avalanche, $(B)$ Mill Ridge (Virginia/West Virginia) rock slump, (C) Elkhorn Mountain (West Virginia) rock avalanche, and $(D)$ Sinking Creek Mountain (Virginia) rock block slide complex. Each map covers the corresponding area shown in figure 9.2. Bar scales are $1 \mathrm{~km}$. 

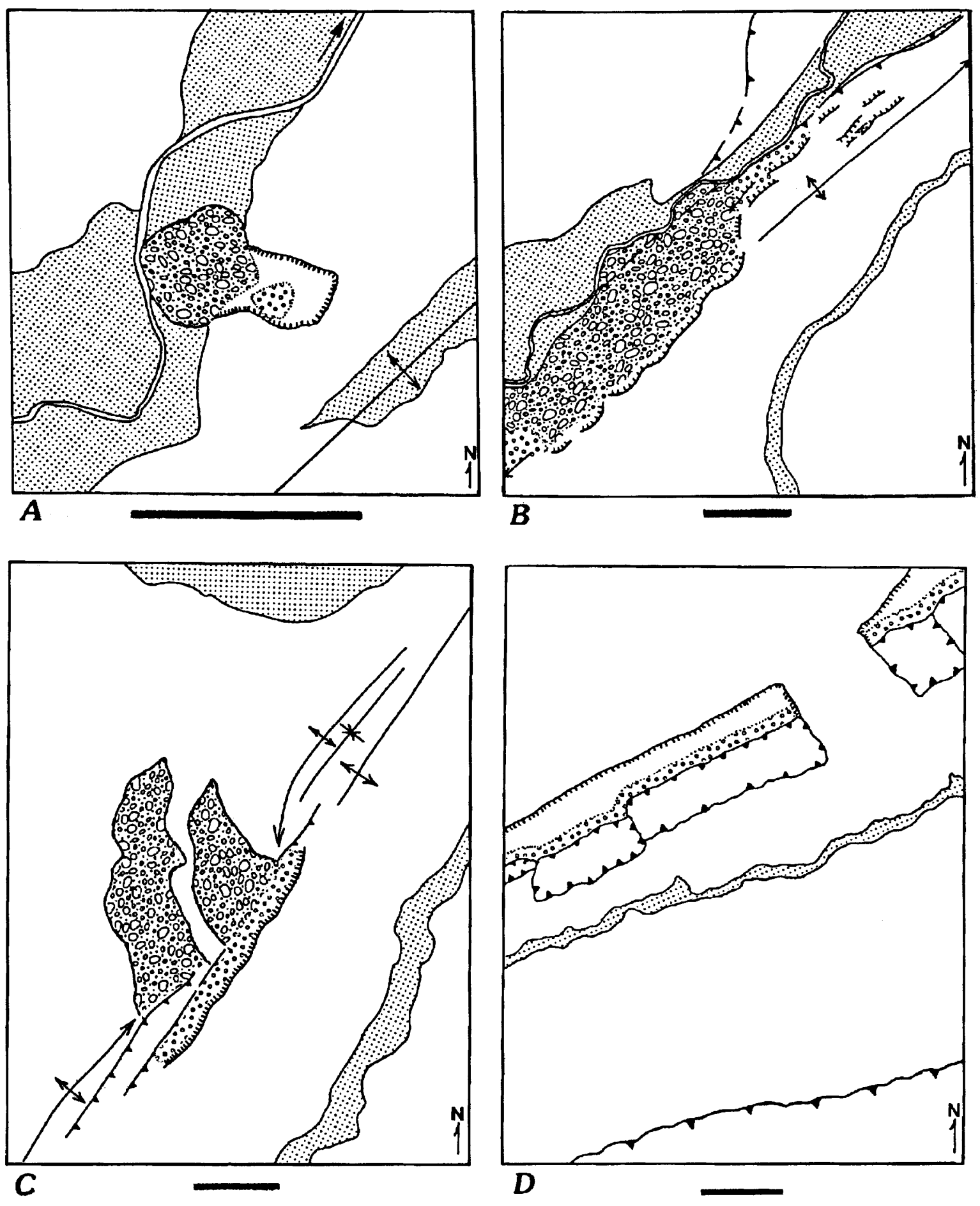

EXPLANATION

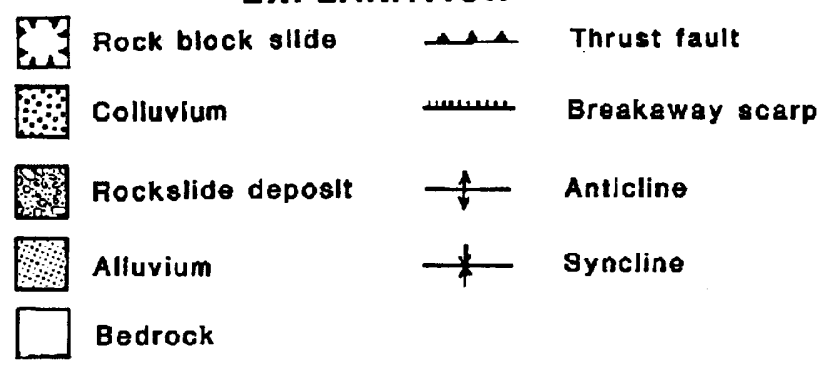


catastrophic failure. Field characteristics are active scree slopes on the scar left by removal of debris and a lobate deposit at the base of the slope. Because of the inferred velocity of mass movement, debris deposits are not in direct contact with the base of the slope.

Type examples of rock slump, rock avalanche, debris avalanche, and rock block slide are characterized in table 9.2 and illustrated in figures 9.2 and 9.3. All rockslides occur on the limbs of anticlinal folds. Most "breakaway" head scarps occur along longitudinal joints at the crest of the mountain near the axial trace of the fold; some are restricted to the dip-slope flank. All rockslides include sandstone or quartzite, but a few include shale or limestone from underlying units. Most detachment surfaces are planar at or near the sandstone contact with limestone or shale. Some detachment surfaces are inferred to be concave upward because of the geometry of the slope and blocks. Interpreted morphology of a rock avalanche and rock block slide is schematically shown in figure 9.4.

Various stages of rock failures and variable amounts of subsequent erosion suggest that the rockslide process has been active for a long period of time. Large, vertical fissures in bedrock on anticlinal limbs suggest an initial stage of lateral spreading prior to the actual rock slump. In places, adjacent hogbacks with opposing dip direction suggest initial gravity collapse. The progressive stages associated with rock block slides include (1) an initial bulge of bedrock, (2) distinct allochthonous blocks that can be reconstructed to their original position, and (3) isolated remnants of blocks. Rock and debris avalanche deposits are highly eroded and covered with an extensive deciduous forest; the head regions, however, have active scree slopes and debris chutes. Debris avalanche deposits may rest on the present flood plain. In other situations, only a massive scar on the mountain remains; the debris apparently has been long removed by the same fluvial erosion that probably triggered its formation.

\section{CAUSES}

Speculative causes of Appalachian rockslides include paleofluvial cut-bank erosional processes, climatic extremes and fluctuations, and seismic shaking. Approximately half of the rockslides described in table 9.2 are believed to have been triggered by paleofluvial cut-bank erosion of the base of the dip slope. Present drainage at the base of the slope and the relationship of the rockslides to adjacent water gaps and incised, ancient fluvial terraces suggest undercutting as a cause. High precipitation, high rates of degradation, and temperature extremes associated with periglacial climate of the Pleistocene may have produced an acceleration factor in fluvial erosion as well as an increase in pore pressure of rock caused by oversaturation. The apparent clustered distribution of rockslides near seismic zones (Schultz, 1986; Southworth and Schultz, 1986) suggests that seismic shaking may also be a possible mechanism for rockslide initiation. More than 13 rockslides and (or) rockslide complexes occur close to the Giles County, Virginia, seismic zone. This zone was the source of the second largest known earthquake in the Southeastern United States (Bollinger and Wheeler, 1983). In addition, three rockslides occur along a cross-strike structural zone that is close to three noninstrumental seismic epicenters (Southworth, 1986).

\section{SUMMARY}

Various stages of prehistoric giant rock slumps, rock block slides, rock avalanches, and debris avalanches have been recognized in the Appalachian Valley and Ridge province. The different amounts of subsequent erosion suggest that the rockslide process has been active for a long time. The giant rockslides are relict features of extreme erosive, climatic, and (or) seismic conditions never before recognized in this region. Their identification represents a newly recognized geomorphic process in the Valley and Ridge province. Many of the rockslides have previously been mistaken for Alleghenian-age folds and thrust sheets. Characterization of the rockslides suggests a consistent structural setting and dominant rock type. Examination of similar geologic settings of dip slopes of resistant rocks throughout the Appalachian Valley and Ridge province may better define the relationship between slope failure and stratigraphy, structure, stream erosion, climate, and seismicity.

\section{REFERENCES CITED}

Bollinger, G.A., and Wheeler, R.L., 1983, The Giles County, Virginia, seismic zone: Science, v. 219, p. 1063-1065.

Braddock, W.A., 1978, Dakota Group rockslides, northern Front Range, Colorado, U.S.A., in Voight, Barry, ed., Rockslides and avalanches; 1, Natural phenomena: Developments in geotechnical engineering 14A: New York, Elsevier, p. 439-479.

Cruden, D.M., 1976, Major rock slides in the Rockies: Canadian Geotechnical Journal, v. 13, p. 8-20.

Mollard, J.D., and Janes, J.R., 1984, Airphoto interpretation and the Canadian landscape: Energy, Mines and Resources, Canadian Government Publishing Centre, Quebec, Canada, 415 p.

Mudge, M.R., 1965, Rockfall-avalanche and rockslideavalanche deposits at Sawtooth Ridge, Montana: Geological Society of America Bulletin, v. 76, p. 1003-1014. 


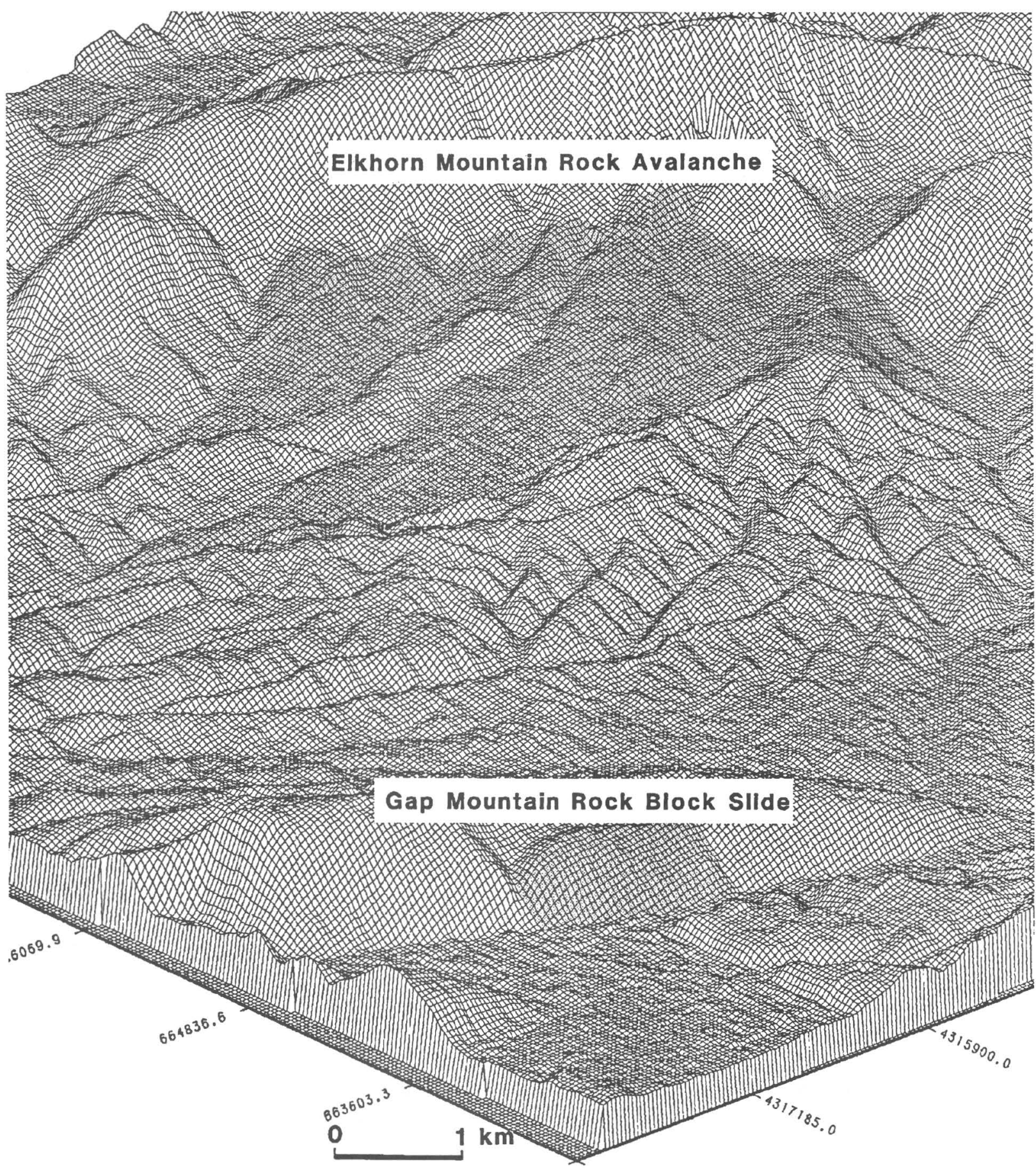

Figure 9.4. Isometric perspective of digital elevation model data of a portion of the Petersburg East (West Virginia) 7.5minute quadrangle illustrating the morphology of the Elkhorn Mountain rock avalanche (see figures $9.2 C$ and 9.30 ) and Gap Mountain rock block slide (table 9.2). View is to the southeast with a $45^{\circ}$ oblique inclination and a 2:1 vertical exaggeration. 
Schultz, A.P., 1985, Mega-rockslide complex, Sinking Creek anticline, southern Appalachians (abs.): Geological Society of America Abstracts with Programs, Southeastern Section, v. 17, no. 2, p. 134.

- -1986 , Ancient, giant rockslides, Sinking Creek Mountain, southern Appalachians, Virginia: Geology, v. 14, no. 1, p. 11-14.

Southworth, C.S., 1986, Radar image analysis for mapping Central Appalachian cross-strike structural discontinuities, in International Symposium on Remote Sensing of Environment, Fourth Conference on Remote Sensing for Exploration Geology, San Francisco, 1985, Proceedings: Ann Arbor, Michigan, ERIM, v. 2, p. 539-551.
Southworth, C.S., and Schultz, A.P., 1986, Characteristics of giant rockslides in the Appalachian Valley and Ridge, Virginia, West Virginia, Maryland, and Pennsylvania: U.S. Geological Survey Open-File Report 86-94, 4 p., 3 oversized sheets.

Varnes, D.J., 1978, Slope movement and types and processes, in Landslides: Analysis and Control: Transportation Research Board, National Academy of Sciences, Washington, D.C., Special Report 176, p. 11-33.

Watson, R.A., and Wright, H.E., Jr., 1967, The Saidmarreh Landslide, Iran: Geological Society of America, Inc., Special Paper 123, p. 115-139.

\section{FAILURE KINEMATICS OF ANCIENT GIANT ROCK BLOCK SLIDES AND ROCK SLUMPS, SOUTHERN APPALACHIAN VALLEY AND RIDGE PROVINCE}

\section{Arthur P. Schultz}

Giant rock block slides and rock slumps on dip slopes in the Appalachian Valley and Ridge province of southwest Virginia range from individual failures involving 5,000 cubic meters of rock to rockslide complexes containing at least 1 billion cubic meters of rock. Field mapping (Schultz, 1985, 1986; Southworth and Schultz, 1986) has shown that these large features are more common than previously recognized and indicates that large-scale dip-slope failure has been a dominant topographic modification process in the Valley and Ridge province.

The rock block slides and rock slumps are found predominantly on southeast slopes composed of sandstone, siltstone, and shale of Silurian age. Characteristic topographic breaks and vegetation changes aid in their recognition (Schultz, 1985, 1986; Southworth and Schultz, 1986). Slide morphology is controlled by bedrock dip (Schultz, 1986). Where beds dip steeply (45 degrees or more), rock slides are relatively small and confined to the uppermost parts of the slope. Where dips are less than 30 degrees, slides are larger, areally extensive, and have undergone greater transport downslope. Folds within the slide sheet may reflect the configuration of the detachment and shear surface. This surface is inferred to be bedparallel high on the dip slope and a shear plane which transects bedding lower on the slope. Although the slip surface is presently not exposed, outcrops of slide rocks within a few meters of the base are composed of alternating thin-bedded sandstones and shales. Sliding probably took place along the shale beds.

Giant rockslides and rock slumps range from incipient failures with minor downslope transport to eroded remnants of large slide sheets on the lower slope. This suggests that dip-slope failures occurred over extended periods of time. No evidence of recent movement has been found. Relative dating of the slides based on weathering profiles and block streams (Schultz, 1986) places them in the Pleistocene to early Holocene.

The kinematics of the giant rock failures can be inferred from the variety of rockslides present in the Valley and Ridge province. Early rockslide failure (fig. 10.1) involves downslope sagging and bulging. Bedding along the toe and outside margins of the slide is folded. Anomalous valleys along the ridge crest form in response to the early separation. These internally drained depressions may have facilitated further instability by increasing the ground water flow along the base of the unstable block. Anticlinal folding of the toe of the rockslide occurs to accommodate shortening. The anticlines are preserved only in rock block slides with minimal displacement. Continued downslope transport of the slides occurred with brittle fracture along lateral break-away scarps. Following these early stages of rockslide failure, two types of rockslides developed: rock block slides or rock slumps. Where dips of beds are relatively high (45 degrees or more), relatively small slump blocks (fig. 10.1) formed with little downslope displacement. During emplacement, possible rotation of the blocks about a horizontal and (or) vertical axis may have resulted in both a topographic and structural reversal high on the dip slope. Where dips are less than 30 degrees, relatively large rock block slides formed that moved downslope as coherent sheets (fig. 10.1). These sheets overrode their folded toes and were folded as they slid across the detachment and shear plane and eventually across the preexisting erosion surface of the lower slope. In some cases, the frontal sections of the rock block slides were further modified by later rock fall and rock slumping. In other cases, formation of large slump complexes (fig. 10.1) 


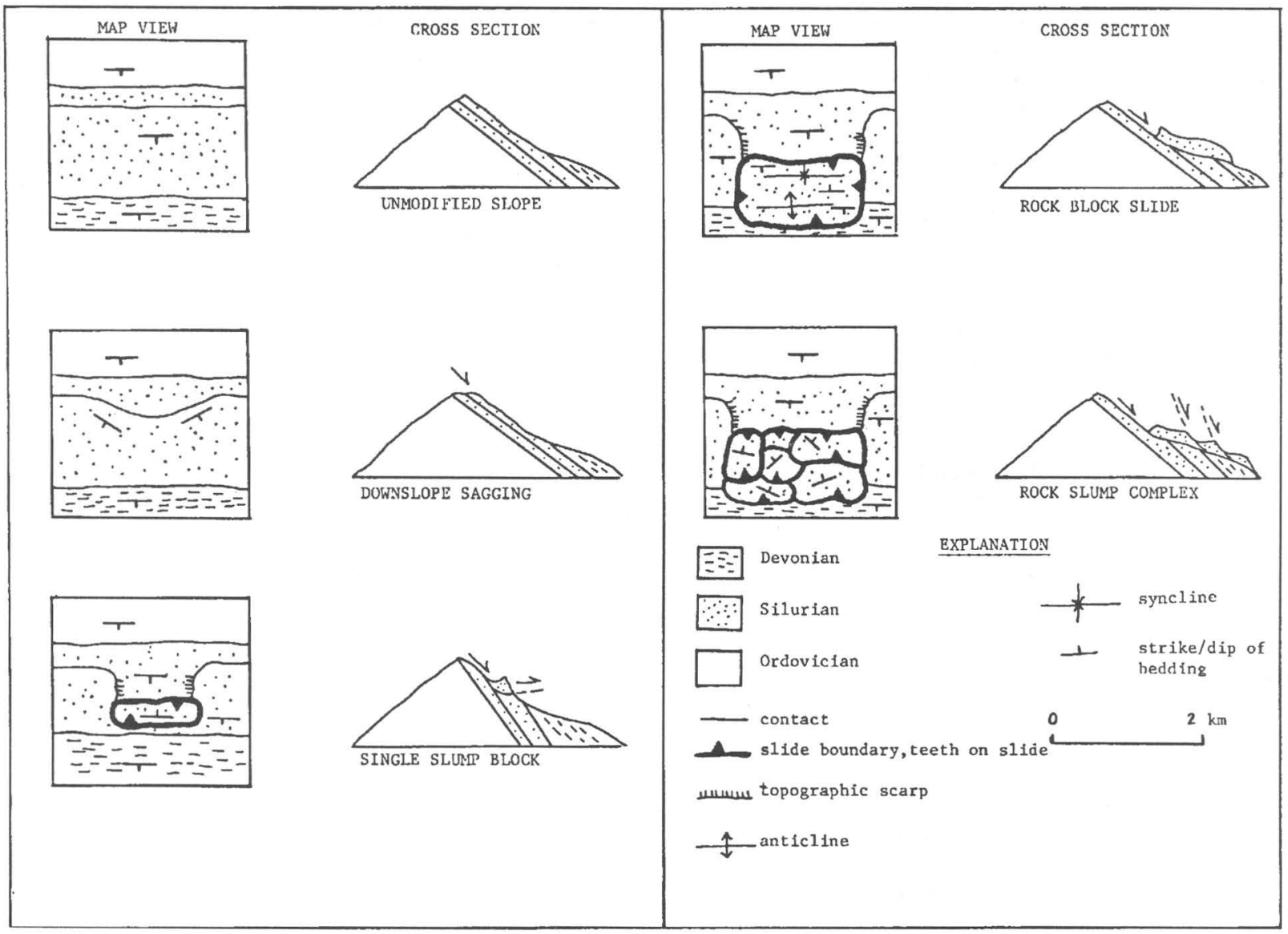

Figure 10.1. Schematic maps and cross sections showing various stages of failure of giant rock block slides and slumps.

reflects breakup of the large failed block during and (or) after slide sheet emplacement. The complexes consist of a mass of internally rotated blocks transported varied distances. Hummocky topography is characteristic. The distribution of rock block slides and rock slumps and fluvial terraces suggests that undercutting was not a mechanism that contributed to initial slope instabilities. Paleoseismicity may have contributed to slope failure, and slides are found near presently active low-level seismic zones. Climatic conditions during the Pleistocene and earliest Holocene may have been more favorable for the initiation of slope failure than they are at present.

\section{REFERENCES CITED}

Schultz, A.P., 1985, Mega-rockslide complex, Sinking Creek anticline, Southern Appalachians (abs.): Geological Society of America Abstracts with Programs, Southeast Section, v. 17, no. 2, p. 134.

- - - 1986, Ancient, giant rockslides, Sinking Creek Mountain, Southern Appalachians, Virginia: Geology, v. 14, no. 1, p. 11-14.

Southworth, C.S., and Schultz, A.P., 1986, Characteristics of giant rockslides in the Appalachian Valley and Ridge, Virginia, West Virginia, Maryland, and Pennsylvania: United States Geological Survey Open-File Report 86-94, 4 p., 3 oversized sheets. 


\section{RECOGNITION OF DISAGGREGATED ROCK BLOCK SLIDES IN A STRUCTURALLY COMPLEX TERRANE IN VIRGINIA}

\section{Thomas M. Gathright II ${ }^{1}$ and Eugene K. Rader ${ }^{1}$}

Multiple thrust faults, overturned horse blocks, klippen, and rock block slides in the Upper Ordovician through Lower Devonian clastic footwall rocks of the Narrows fault in Giles County, Virginia, presented formidable mapping problems in distinguishing between tectonic structures and sheetlike rock block slides (fig. 11.1). Thirteen incised rock block slides, coherent to disaggregated, were identified on the dip slopes of East River and Peters Mountains and on the overturned beds of the Piney Ridge and associated horse blocks.

Lateral scarps, slip-off slopes, and sag ponds typical of rock block slides are poorly preserved on some of the slides. These disaggregated rock block slides have hum-

\footnotetext{
${ }^{1}$ Virginia Division of Mineral Resources, Box 3667, Charlottesville, VA 22903.
}

mocky or ridged surfaces on which the hummocks or ridges range from less than $1 \mathrm{~m}$ to $10 \mathrm{~m}$ in height and are composed of angular fragments and ledge-forming blocks. Some slides are sufficiently intact to preserve original stratigraphic map units.

Rock block slides that developed along slope planes in shale beds of the Silurian Rose Hill Formation are more coherent than those developed in other rock units or in overturned beds. Two slides have significantly offset stream courses and forced the streams to undercut the opposite valley wall.

Several factors may contribute to the extensive disaggregation of these rock block slides. These factors include the proximity of slides to thrust faults where beds may be extensively fractured, the dissolution of carbonate rocks overridden by the slides with subsequent collapse of the slide strata, and the possibility of rapid implacement due to proximity to the Giles County seismic zone.
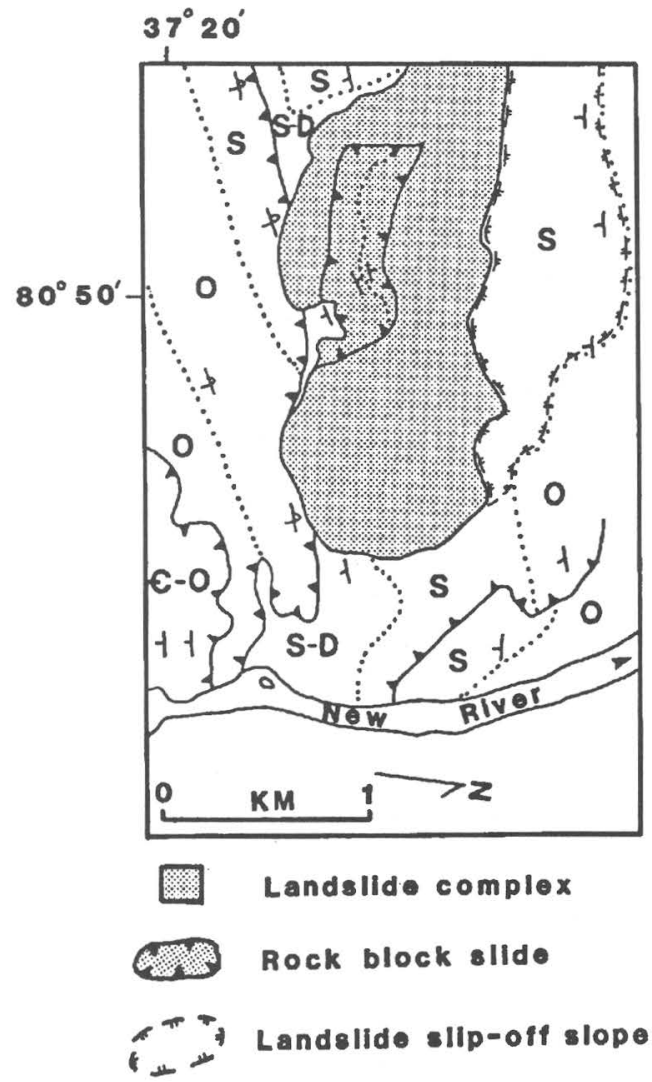
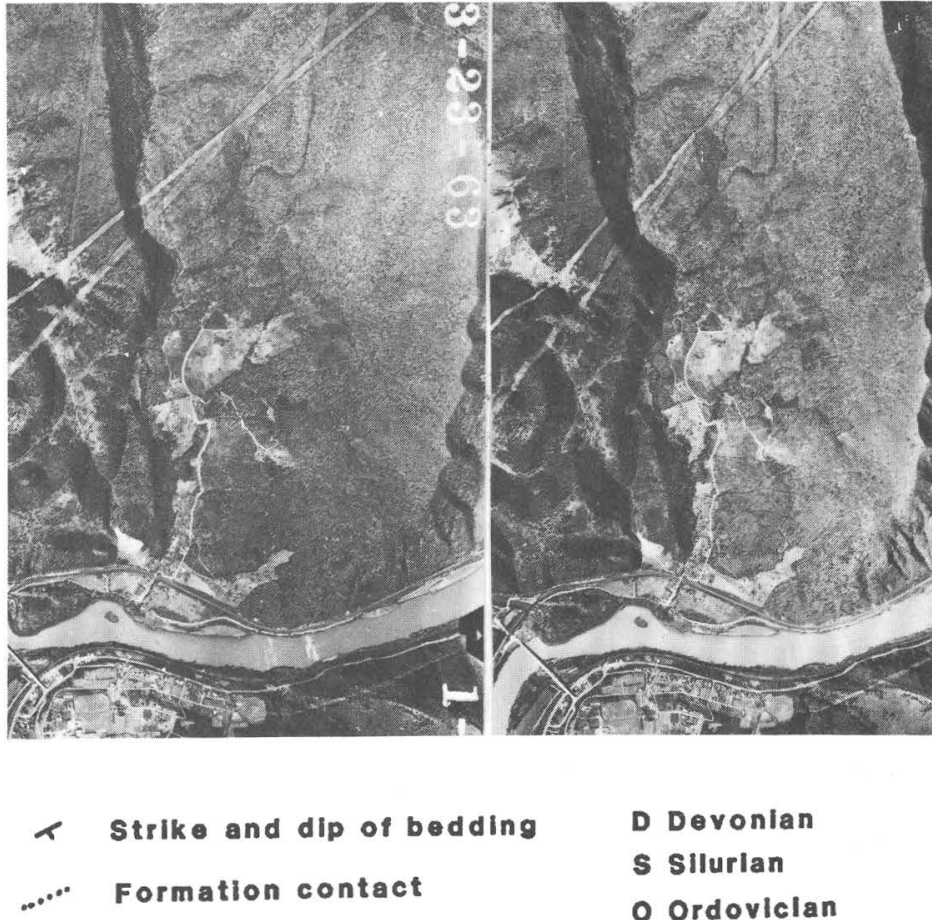

Thrust fault

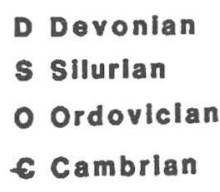

D Devonian

S Silurlan

- Cambrian

Figure 11.1. Stereo-pair aerial photographs and geologic map of a rock block slide complex on the east (dip) slope of East River Mountain near Narrows, Virginia. 


\title{
12. REGIONAL CONTRASTS OF LANDSLIDES IN THE APPALACHIAN HIGHLANDS
}

\section{William E. Davies'}

Each physiographic province in the Appalachian Highlands has different characteristic suites of landslides. These suites reflect different rock and soil types and their reaction to precipitation. Landslides in the northern Piedmont are not common and are generally small soil slipouts. Southwards, the slides increase in number and size and culminate in North Carolina in large, complex slumps.

The Blue Ridge slides are dominantly large rockslides developed along joint fracture planes. Most of these slides result from highway construction. Large debris

${ }^{1}$ U.S. Geological Survey, retired. avalanches and mudflows occasionally occur during periods of very heavy precipitation.

Complex soil slumps, debris avalanches, and mudflows are prevalent in the Valley and Ridge province. Most of the slopes are stable except during periods of very heavy rainfall. There are remnants of many prehistoric slides, some of which involve hundreds of millions of cubic yards of rock and soil debris.

More than half of the slopes in the Appalachian Plateaus province are unstable. Their movement is continuous and results in complex soil slumps. In contrast to landslides in the other physiographic provinces, the slides in the Plateaus are not directly related to variations in precipitation.

\section{SLOPE INSTABILITY IN THE APPALACHIAN PLATEAUS PROVINCE, WEST VIRGINIA: NUMEROUS CASES, NUMEROUS CAUSES, FEW CURES}

\author{
Robert E. Behling ${ }^{1}$
}

Numerous landslides occur as a result of the extraction of natural resources in the Appalachian Plateaus province in north-central West Virginia. Predictable outcomes of mining, drilling, and woodland management include undercutting, overloading, alteration of surface and subsurface water conditions, changes in slope configuration, removal of vegetation, and structuring of soil to create mine soil. It is axiomatic that the integrity of slopes above or below such disruptions is in jeopardy. What is not clear, however, is whether the vast number of landslides on natural slopes are inevitable. Experience throughout the Appalachian Plateaus in West Virginia leads this author to believe that a substantial body of information exists that would allow for significant mitigation of slope instability problems.

The lack of base-line data for clay mineralogy and coefficient of linear extensibility (COLE) values is a significant problem. These have been a welcomed addition of several Soil Conservation Service (SCS) county soil surveys in the past 5 years, but coverage of the entire State will not be available until the mid-1990's. SCS personnel are excellent resource people in the field, but they have too limited base-line data regarding clay minerals and COLE values. An excellent review of landslides and slide-prone

\footnotetext{
${ }^{1}$ Department of Geology and Geography, West Virginia University, Morgantown, WV 26506.
}

areas in West Virginia by Lessing and others (1976) focused on the more populated areas of the State. To date, 36 maps are available in the series. There are, however, 495 7.5-minute topographic quadrangle maps that provide coverage of the State. In nearly every case, operators do not have access to publications that could guide their activities in such a way as to mitigate mass movement on slopes adjacent to their property.

It is unreasonable to expect an operator to produce characterization data for soils within and adjacent to properties they wish to develop. What is needed by the operator is a means of determining when additional information would be strongly advised to mitigate potential problems with respect to slope stability.

Two publications reflecting the characterization of soils in the Appalachian Plateaus in southwestern Pennsylvania are applicable to the prediction of landslides in north-central West Virginia (Ciolkosz and others, 1976; Ciolkosz and others, 1979). The work in Pennsylvania specifically aids in the characterization of the Westmoreland, Upshur, and Guernsey residual soils in West Virginia. An extension of these data, with appropriate caution, allows for some predictions regarding the Gilpin residual soil and the Clarksburg colluvial soil. Still further extrapolation may allow for examination of additional landslideprone soils in West Virginia (the Culleoka, Dormont, Wharton, and Zoar residual soils; the Ernest and Vandalia colluvial soils). 
Ciolkosz and others (1979) have clearly identified two critical factors in slope stability: high clay content, with a high proportion of clay minerals of an expandable type, and high COLE values. In numerous case studies, this author has noted that alteration of a slope (undercutting, removal of vegetation, alteration of surface drainage, etc.) established a very great potential for landslide activity. Following prolonged rainfall or very intense, short-term addition of water to the slope, movement of the soil appears to be initiated in the B horizon as Ciolkosz and others (1979) suggest. Initial movement, unfortunately, usually leads to complex movement of materials on the slope.

The nature of the COLE values within profiles of landslide-prone soils in West Virginia remains essentially unknown. Also unknown is that detailed information regarding the characterization of the clay-mineral analyses for landslide-prone soils in West Virginia must be collected. Further, the base-line data must be applied to the slopes prevalent in West Virginia. Armed with these data, operators will then be able to make reasonable predictions regarding slope stability. Only then can operators significantly mitigate the effects of operations on slopes adjacent to their properties.

\section{REFERENCES CITED}

Ciolkosz, E.J., Cunningham, R.L., Peterson, G.W., Matelski, R.P., and Pennock, R. Jr., 1976, Characteristics, interpretations, and uses of Pennsylvania soils developed from redbeds and calcareous materials: Pennsylvania Agriculture Experimentation Station Progress Report 316.

Ciolkosz, E.J., Peterson, G.W., and Cunningham, R.I., 1979, Landslide-prone soils of southwestern Pennsylvania: Soil Science, v. 128, p. 348-352.

Lessing, P., Kulander, B.R., Wilson, B.D., Dean, S.L., and Woodring, S.M., 1976, West Virginia landslide and slideprone areas: West Virginia Geological and Economic Survey, Environmental Geological Bulletin No. 15.

\section{RELATION BETWEEN LANDSLIDES AND BEDROCK IN THE CENTRAL APPALACHIAN PLATEAUS}

\section{William F. Outerbridge}

Studies of landslides in the central Appalachian Plateaus province have shown that landslides are locally abundant and that the landslide population is closely related to the lithology of the rocks that underlie the slopes. These relations are illustrated in the Jenkins $1^{\circ} \times 2^{\circ}$ quadrangle area of Kentucky, West Virginia, and Virginia (fig. 14.1).

The lowest exposed bedrock unit in the Jenkins $1^{\circ} \times 2^{\circ}$ quadrangle is the New Albany Shale of Middle Devonian to Early Mississippian age. In the northwest part of the area, the New Albany Shale is about $60 \mathrm{~m}$ thick. It is laminated, black, pyritic, bituminous shale. The organic material in the shale inhibits weathering; thus the shale lacks soil cover to support vegetation. Soil on slopes developed on the New Albany Shale is rarely more than $10 \mathrm{~cm}$ thick, and bedrock outcrops are abundant. Commonly, the shale forms low flat-topped benches; where the shale is exposed on long steep slopes the surface is gullied. Rarely, debris avalanche deposits can be found in the gullies. In general, where it is undisturbed, no landslides occur in the New Albany Shale, and the shale does not contribute material to landslides originating above it. However, where disturbed, as in vertical road cuts, the New Albany Shale will fail as rock topples and rock falls. Along Pine Mountain (fig. 14.1) the correlative Chattanooga Shale is a major contributor to debris slides; the section is thicker and exhibits intense structural deformation.

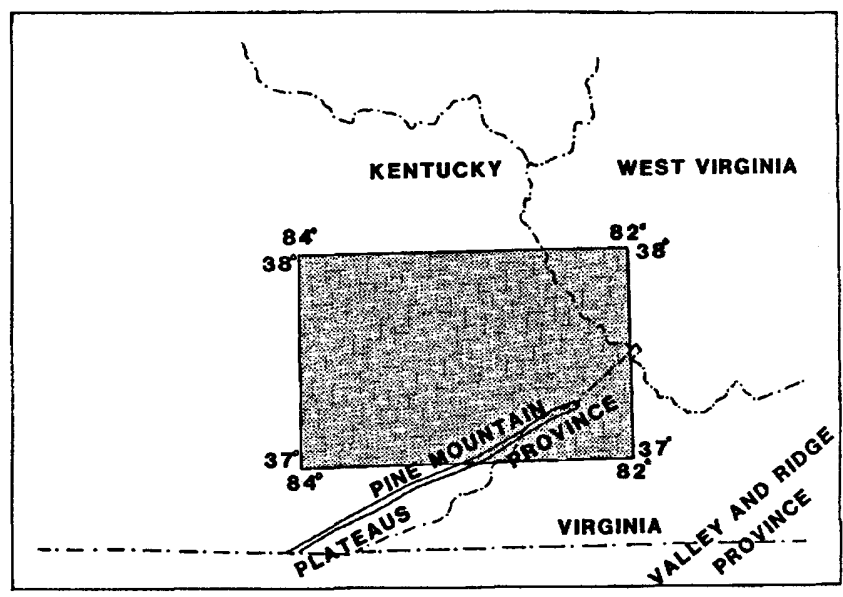

Figure 14.1. Index map of Jenkins $1^{\circ} \times 2^{\circ}$ quadrangle of Kentucky, West Virginia, and Virginia.

Slides readily occur in the Mississippian Borden Formation (table 14.1). The Borden Formation is composed of interbedded siltstone and shale. Either rock type may be locally dominant over fairly thick intervals, but in general, shale is more abundant in the base of the unit and siltstone is more abundant near the top.

The landscape that is underlain by the Borden Formation exhibits wide valleys and steep-sided hills. Debris slide scars and deposits are frequent. Colluvium is 
Table 14.1. Rock types, in order of increasing tendency to fail, and their typical styles of failure. These data are based on observations in eastern Kentucky. Landslide classification after Varnes (1978)

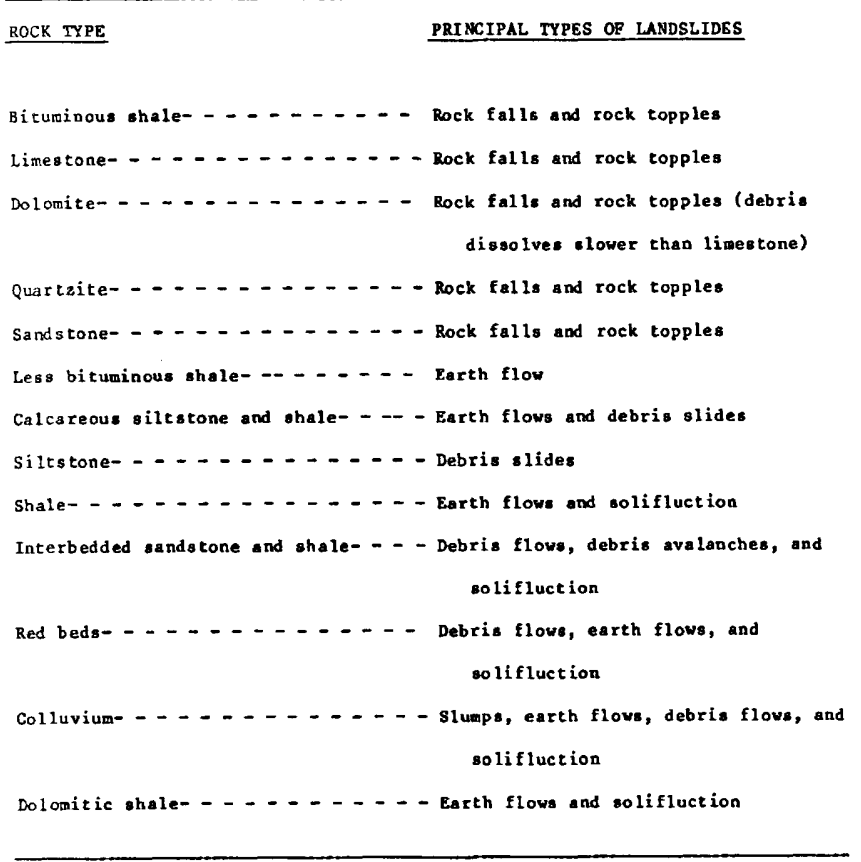

thickest at the base of the slopes. A thin unit of red and green shale and dolomite at the top of the Borden Formation is very weak when wet and contributes to sapping of the overlying Newman Limestone.

The Newman Limestone, of Late Mississippian age, is a cavernous limestone, locally cherty, but generally almost pure. Over much of its occurrence, the Newman Limestone crops out as cliffs above the Borden Formation. It creates a rockfall problem but is generally stable in vertical roadcuts.

Above the Newman Limestone is the Pennington Formation, of Late Mississippian age. The Pennington Formation is mostly a red shale unit with some siltstone and dolomite interbeds. It has a very strong tendency to produce landslides. Earth flows and mud flows are characteristic failures of the Pennington Formation.

The Lee Formation, of Late Mississippian and Early Pennsylvanian age, is a fairly clean quartzitic conglomeratic sandstone. It is a consistent and spectacular cliff former; the cliff country of the Pennsylvanian escarpment in Kentucky owes its existence to the Lee Formation.

The Lee Formation fails mainly by rock falls and rock topples. The sandstone begins to fail along joints as the underlying Pennington Formation erodes away. Large boulders topple from the cliff face and become incorporated in down-slope debris flows. On the dip slope of the northeast end of Pine Mountain, a sandstone block ( $1 \mathrm{~km}$ long and $0.5 \mathrm{~km}$ wide) of the Lee Formation has formed a block slide. The block detached on the Raven coal bed and its underclay.

The presence of the Lee Formation has a stabilizing effect on the lowermost $60 \mathrm{~m}$ of the overlying Breathitt Formation. The Breathitt Formation of Early and Middle Pennsylvanian age is mostly shale. Where the shale is underlain by the Lee Formation, the sandstone makes a firm foundation that supports the Breathitt Formation and creates a zone of very few landslides.

Rockfalls and debris avalanches are characteristic of the Breathitt Formation, which is composed of interbedded sandstone, siltstone, shale, coal, and underclay. The Breathitt Formation forms cliffs and can fail as rock falls on fairly gentle hills as well as in roadcuts. Shale or siltstone, and sandstone commonly are interbedded in thin beds. The interbedded strata are unstable and debris slides and solifluction occur even on fairly gentle slopes. Where shale is thick there is usually a bench due to weathered shale. Debris collects on the bench until it begins to flow downslope. Steep slopes underlain by the Breathitt Formation commonly are sites for debris avalanches. Debris avalanche chutes are commonly only a couple of meters wide throughout their entire length. Other debris avalanche chutes are roughly hourglass shaped, with debris collected from a wide area at the top funneled into a narrow chute and then deposited as a fan at the bottom of the slope. They occur during torrential rains.

Steep slopes occur where sandstone is the dominant bedrock. Beds of sandstone form small cliffs and ledges in slopes that may have an average grade of 80 to 100 percent or more. Thicker beds of sandstone form cliffs up to about $30 \mathrm{~m}$ high. Such slopes present a rock fall hazard.

Excepting rock falls, rock topples, and block glides, there is very little bedrock involvement in landslides in the Appalachian Plateaus province. Landslides are confined to colluvium and to the very thin weathered zone above bedrock. The weathering characteristics of the underlying rock determine the characteristics and composition of the soil that forms. It is these characteristics that determine the type of landslide.

Observation of landslides and bedrock in the Jenkins, Kentucky, West Virginia, and Virginia $1^{\circ} \times 2^{\circ}$ quadrangle generally suggests that the local rock types can be listed in order of increasing likelihood of slope failures (table 14.1).

\section{REFERENCES CITED}

Varnes, D.J., 1978, Slope movement and types and processes in landslides: Analysis and control: Transportation Research Board, National Academy of Sciences, Washington, D.C., Special Report 176, p. 11-13. 


\section{MICROCOMPUTER SOFTWARE FOR COMPREHENSIVE STABILITY ANALYSES OF POTENTIAL ROCKSLIDES}

\section{Chester F. Watts'}

A package of 12 microcomputer programs, written to analyze the stability of rock slopes along highway roadcuts, was developed at Purdue University and has been refined at Radford University in cooperation with the U.S. Bureau of Mines. The new IBM-PC-compatible ${ }^{2}$ software package named ROCKPACK (for ROCK Slope Stability Computerized Analysis PACKage) provides detailed analyses of geologic structures that could lead to hazardous slides in rock slopes. ROCKPACK has been used to analyze the stabilities of building excavations, quarries, mines, highway roadcuts, and natural rock slopes in Virginia, New York, New Jersey, Massachusetts, Indiana, and New Mexico. The Oregon State Highway Division is utilizing the software package in its rockslide mapping and inventory program.

ROCKPACK programs (fig. 15.1) are divided into three major categories: (1) field data collection and display, (2) preliminary kinematic analyses by stereonet projections, and (3) detailed quantitative stability analyses of those potential failures identified on the stereonet projections.

The FIELDAT and AFTRDAT programs are for data collecting. Detailed field surveys of the attitudes and physical characteristics of rock-mass discontinuities, such as joints, faults, shear zones, bedding surfaces, and foliations, are required for comprehensive stability analyses of rock slopes. Among the physical characteristics which can affect slope stability are geometry, continuity, spacing, surface irregularities, physical properties of adjacent rock, presence and properties of infilling material, and groundwater conditions. Field surveys conducted to collect these data are generally time consuming and arduous.

The FIELDAT program was developed to record the necessary structural-geologic data quickly and efficiently into the memory of a hand-held computer carried in the field. The Oregon State Highway Division has found the Hewlett-Packard HP71-B computer to be ideal for collecting data with FIELDAT. Once collected, data are easily transferred to desk-top computers via communications interfaces. AFTRDAT may be used to enter field data directly into desk-top microcomputers when handheld computers are not available for use in the field. The DISDAT program provides a computer printout and graphic display of the recorded data.

1 Department of Geology, Radford University, Radford, VA 24142.

${ }^{2}$ Any use of trade names and trademarks in this publication is for descriptive purposes only and does not constitute endorsement by the U.S. Geological Survey.
The EQNET, MRKLND, and GRTCRCL programs create skeletal stereonet projections of the discontinuity orientations on standard dot-matrix printers. These stereonet projections facilitate rapid identification of geologic structures, or combinations of structures, potentially hazardous to existing or proposed rock excavations. To assist in the recognition of discontinuity clusters on stereonets, the RECTCON and SNETCON programs contour the orientation data.

The quantitative stability-analysis portion of ROCKPACK currently consists of four programs. The DSI program calculates a Discontinuity Significance Index (DSI) for each discontinuity and plots the index values on stereonets. These DSI values allow discontinuities that are most significant to the stability of the rock mass, in terms of dip, roughness, length, continuity, and water conditions, to be identified so that they may receive appropriate attention during analysis, design, and excavation. The PLANE program is used to calculate the factor of safety against translational sliding of a rock mass along a single discontinuity. It uses limit-equilibrium theory and can account for the influences of external loading, water pressures, rockbolt or cable forces, and earthquake or blasting accelerations. The RAPWEDG and CMPWEDG programs calculate the factor of safety against sliding of a rock wedge formed by the intersection of discontinuities in the rock mass. The wedge programs account for the effects of water pressures and permit different cohesion and friction parameters to be applied to the two failure surfaces. CMPWEDG also permits the addition of tension cracks, external loads, and rockbolt cable forces.

In Virginia, ROCKPACK software has been used to analyze a 280 -foot, nearly vertical highway rock cut at Cedar Bluff. The analyses indicated three potential rockslide areas on or near the site. The first was an area of potential bedding-plane failures in a nearby railroad cut extending parallel to the strike of the dipping sedimentary strata. The second was a large potential plane failure along a secondary thrust fault within the rock mass. The third was a potential wedge failure formed by the intersection of a bedding-plane fault and a joint set. Safety-factor calculations indicated that the potential wedge failure was unsafe, and subsequent failure partially closed the highway.

Another new software package, called BACKPACK, has been developed at Radford University at the request of the U.S. Bureau of Mines. BACKPACK programs are used to back-calculate rock-mass strength characteristics from existing rockslides in surface mines and to assist in the design of artificial support systems for rock slopes. 


\section{ROCKPACK FLOWCHART}

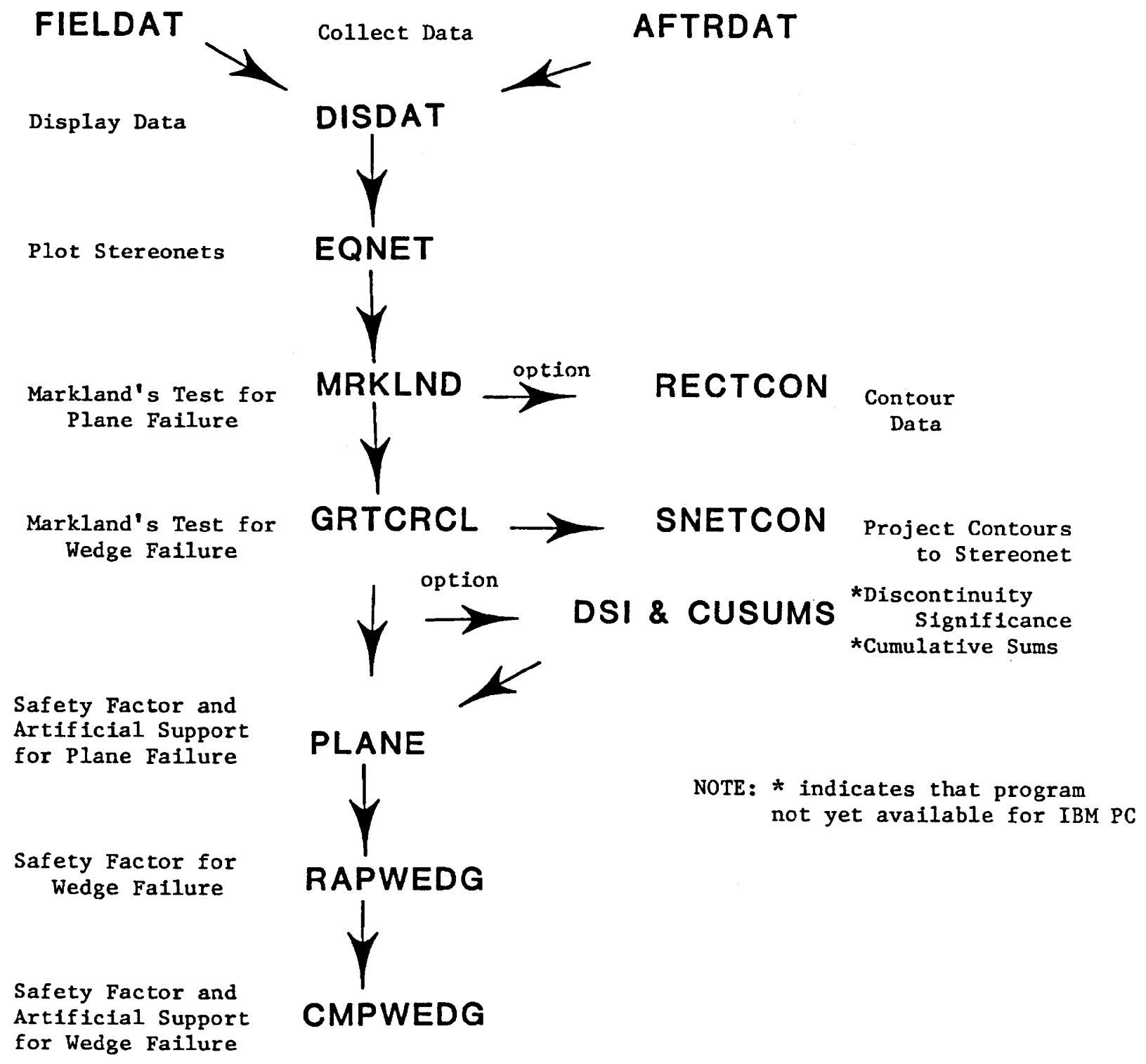

Figure 15.1. Flow chart of ROCKPACK slope stability programs illustrating the recommended sequence of use.

\section{REFERENCES CITED}

Watts, C.F., 1983, Development, testing, and evaluation of a microcomputer system for rapid collection and analysis of geologic structure data related to rock slope stability: Ph.D. thesis, Department of Geosciences, Purdue University, West Lafayette, Indiana, $386 \mathrm{p}$.
Watts, C.F., and West, T.R., 1985, Electronic notebook analysis of rock slope stability at Cedar Bluff, Virginia: Bulletin of the Association of Engineering Geologists, v. 22, no. 1, p. 67-85.

- - 1986, Discontinuity significance index and electronic data collection for rock slope stability studies: Bulletin of the Association of Engineering Geologists, v. 23, no. 3, p. 265-278. 


\section{Arthur P. Schultz}

Field trip stops 2 and 3 are overlooks of the typical geomorphic expression of giant ancient rockslides on Sinking Creek Mountain, Virginia (Schultz, 1985, 1986). Similar large features have recently been recognized elsewhere (Southworth and Schultz, 1986) and are presently under study in the central and southern Appalachian Valley and Ridge province. The rockslides on Sinking Creek Mountain are comparable in size to features more commonly associated with the high relief, active seismicity, and climatic extremes of the Cordilleran mountain ranges. The rockslides are located on the southeast limb of the Sinking Creek anticline, an Alleghenian fold near the northern terminus of the southern Appalachian fold and thrust belt (fig. 16.1). Cambrian through Mississippian sedimentary rocks on the southeast limb of the anticline dip from $22^{\circ}$ to $60^{\circ}$ southeast and strike from N.55 E. to N. $65^{\circ} \mathrm{E}$. Silurian clastic rocks are present along the crest and southeast flank of Sinking Creek Mountain, which rises from 350 to $650 \mathrm{~m}$ above the adjacent valleys. The valley on the northwest is composed of Cambrian and Ordovician carbonate rocks; the valley to the southeast is composed of shale and siltstone of Devonian age. In the absence of modifying rockslides, the Silurian Keefer Sandstone crops out in a series of flatirons on the dip slope of Sinking Creek Mountain. The older Silurian Rose Hill Formation and Silurian Tuscarora Quartzite form narrow outcrops along the crest of Sinking Creek Mountain. The slide complex consists of more than seven major rock block slides and rock slumps. These range from 0.8 to 5.0 $\mathrm{km}$ long, from 0.25 to $0.5 \mathrm{~km}$ in width, and from 25 to 100 $\mathrm{m}$ in thickness. The blocks have been transported downslope from 0.5 to $1.5 \mathrm{~km}$. The rockslides form anomalous, linear, subparallel benches, isolated knobs, and slope reversals on the dip slope and lower slopes of Sinking Creek Mountain. These slope reversals form high, flat areas that contain springs, small subsequent streams, swamps, ponds, and circular to elliptical depressions from 10 to $100 \mathrm{~m}$ across. Evergreen vegetation, which mantles the rockslide benches, is in contrast to the surrounding deciduous forest developed on the younger Devonian shaly rocks of the lower slopes. On the east face of the benches are 10- to 30-m-high sandstone cliffs of the Middle Silurian Rose Hill Formation and Keefer Sandstone. Bedding in these cliffs dips from $5^{\circ}$ to $30^{\circ}$ to the northwest, in sharp contrast with bedrock on the dip slopes of Sinking Creek Mountain. The northwest-dipping rocks are right side up, in normal stratigraphic sequence, and strike from $5^{\circ}$ to $30^{\circ}$ from regional trends. Within discrete topographic benches, the uniform bedding dips indicate that these are intact slide blocks. The slip surface of the rockslides has not been seen in the field; however, in valleys that incise the

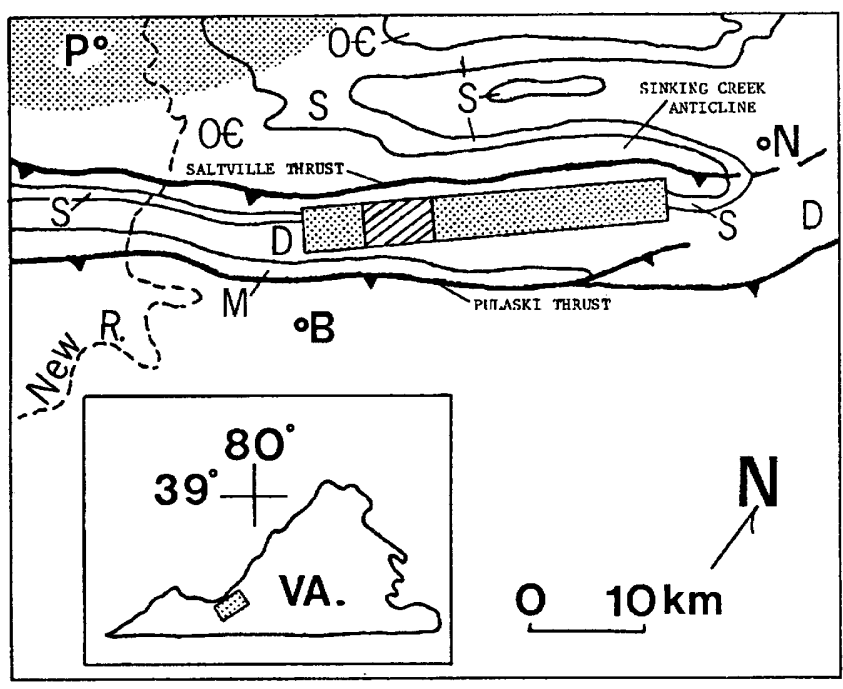

Figure 16.1. Regional index map and geologic map of the Sinking Creek slide complex. Circles with letters are $B$, Blacksburg, Virginia; N, Newport, Virginia; and P, Pearisburg, Virginia. Age designations are M, Mississippian; D, Devonian; S, Silurian; O€, Ordovician through Cambrian. Dot pattern in rectangle is extent of Sinking Creek slide complex; diagonally ruled area shows location of area in figure 16.2. Dot pattern in upper left corner is part of Giles County seismic zone.

slide blocks, right-side-up southeast-dipping Devonian shale is exposed below outcrops of northwest-dipping Silurian sandstone. Cross-strike topographic breaks in the slide area are lateral break-away scarps in autochthonous bedrock high on the dip slope and on the edges of slide blocks farther downslope. Slide blocks truncate formation contacts where older rocks have overridden younger rocks along the base of Sinking Creek Mountain. Where rocks of the uppermost Rose Hill and the Keefer have moved downslope by sliding, the remaining part of the Tuscarora and the Rose Hill form a dip slope on Sinking Creek Mountain and produce an atypically wide outcrop belt (fig. 16.2). All the slide blocks are extensively weathered. Short, steep-gradient streams have dissected the slide blocks. Boulder streams of Silurian sandstone and quartzite extend from the slide-block scarps downslope and override older colluvium. Bending, tilting, or kinking of trees was not observed in the slide area.

The topographic, structural, and stratigraphic data suggest that large sections (100 to 500 million cubic meters) of the southeast flank of Sinking Creek Mountain detached along bedding planes and joints and slid downslope. Initial detachment was probably near the Rose Hill- 


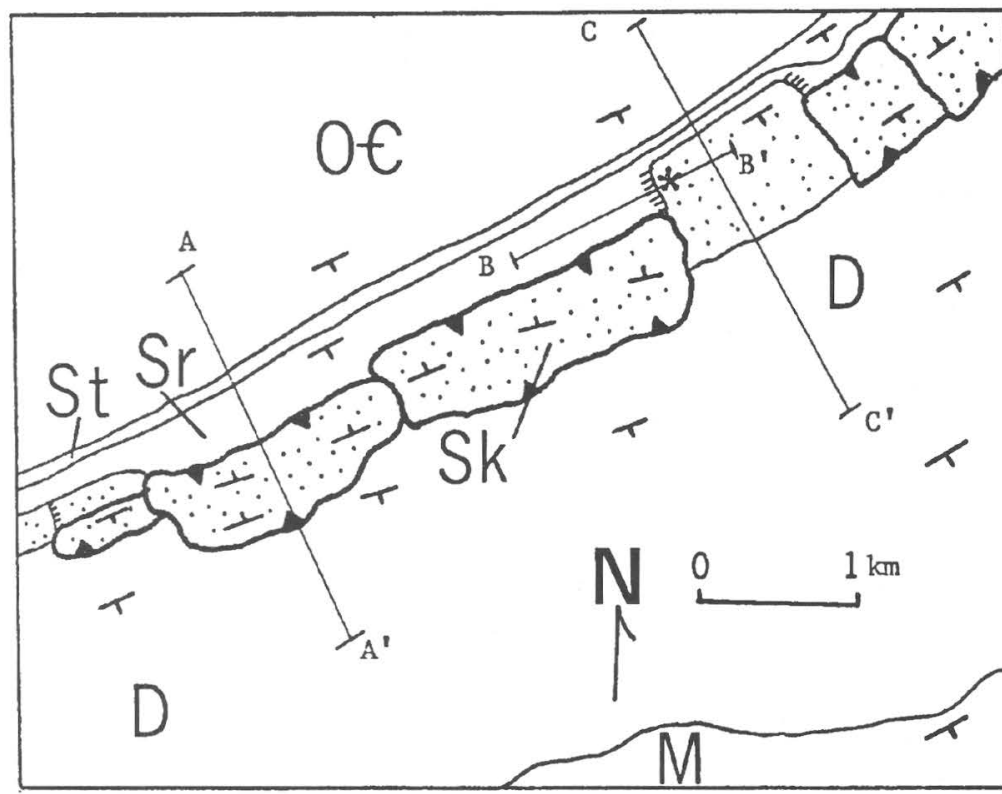

\section{EXPLANATION}

M Mississippian

D Devonian

Sk Silurian Keefer Formation

Sr Silurian Rose Hill Formation

St Silurian Tuscarora Quartzite

of Ordovician-Cambrian

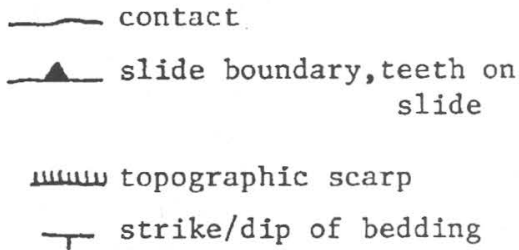

A

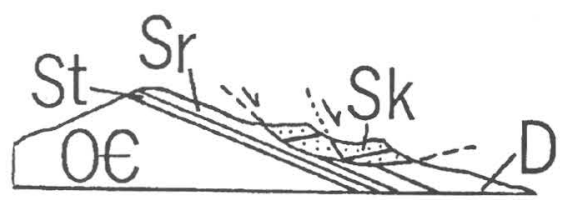

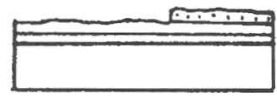

$B^{\prime}$

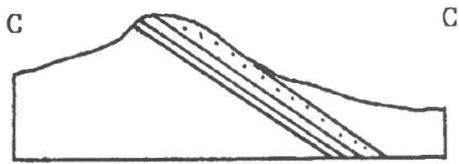

Figure 16.2. Geologic map and cross sections of a portion of the Sinking Creek slide complex that is seen from stop 3.

Keefer contact and (or) in the upper part of the Rose Hill Formation. Several shale beds in this part of the Silurian stratigraphic section could provide surfaces of weakness for detachment and sliding. In outcrop, these shales are weathered to clay. During the early stages of sliding, the blocks underwent translational sliding parallel to bedding on the upper dip slopes. Continued movement lower on the mountain included rotational sliding, possibly along a slip plane that cut upward to the land surface. Shortly after emplacement and (or) during subsequent weathering, large parts of the slide failed by slumping. The blocks moved farther downslope, rotating both bedding and possibly the early slip surface. Prolonged weathering and erosion have reduced the original extent of the slide blocks. Extensive colluvium derived from the rockslide escarpments postdates colluvium that was present on the dip slope prior to sliding. This older colluvium is probably no older than Pleistocene age, which suggests a maximum age of no greater than 2 million years for rockslide emplacement.

Possible triggering mechanisms for the rockslides include undercutting of the base of the dip slope by streams, changes in rock pore pressure related to mois- ture content (climate), catastrophic storms, and seismic shaking.

Specific features noted from overlook stop 2 are the large knobs on the lower slopes of Sinking Creek Mountain. The knobs, which are covered with evergreens, consist of northwest-dipping sandstone and shale of Silurian age lying structurally and topographically above southeast-dipping Devonian shale. The outcrop belt is the eroded remnant of a 4-km-long, folded rock block slide sheet.

From overlook stop 3 (figs. 16.2 and 16.3), rockslides of different relative ages can be seen as well as the topographic expression of break-away scarps. Block streams derived from the frontal scarp of the most recent large rockslide are presently close to the valley bottom. Numerous stages of rock block slide failures are found here (figs. 16.2 and 16.3).

\section{REFERENCES CITED}

Schultz, A.P., 1985, Mega-rockslide complex, Sinking Creek anticline, southern Appalachians (abs.): Geological Society of America Abstracts with Programs, Southeastern Section, v. 17, no. 2, p. 134. 


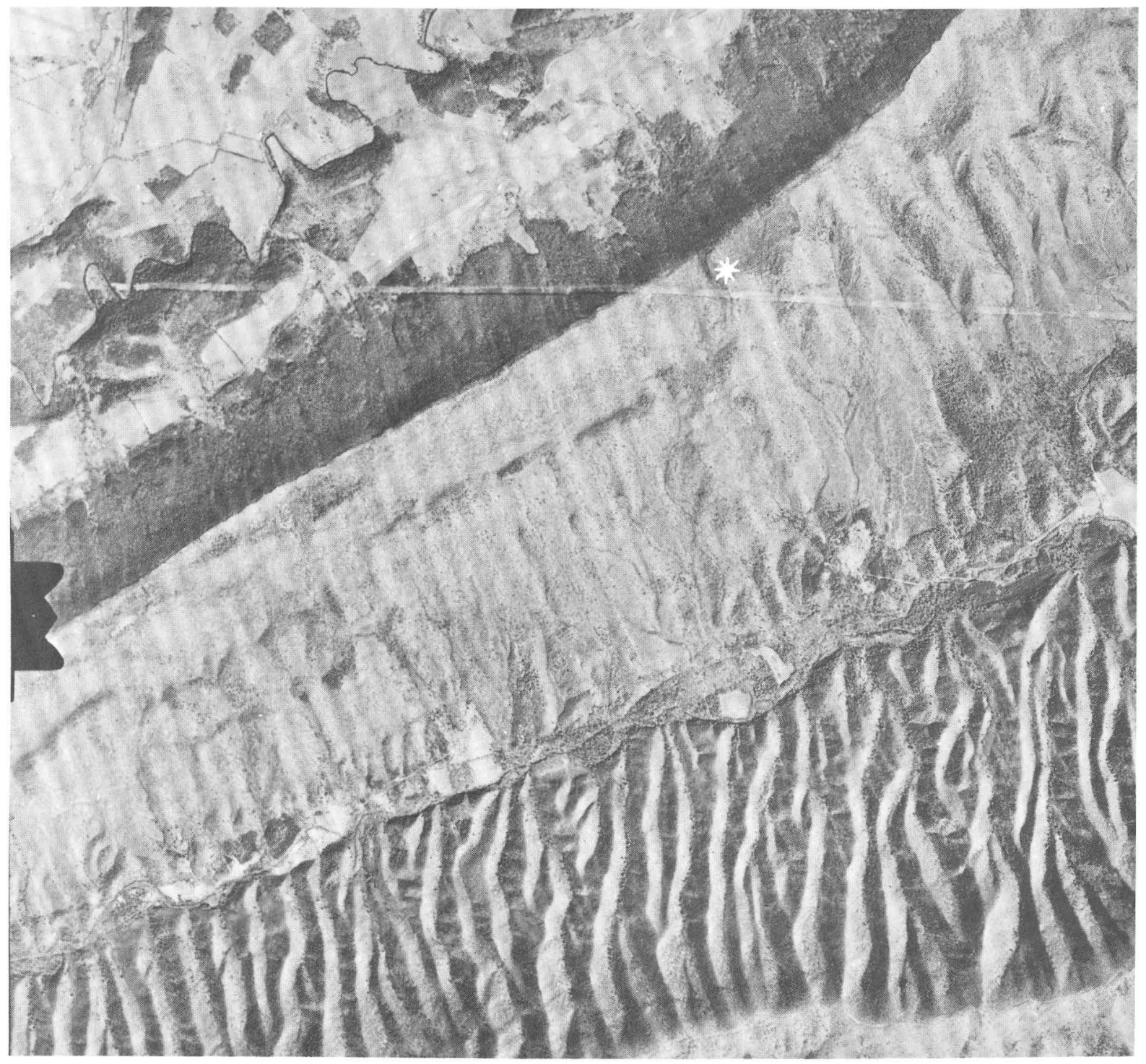

Figure 16.3. Aerial photograph of area in figure 16.2. Asterisk on photograph is in same position as on figure 16.2 near the power line.

- - 1986, Ancient, giant rockslides, Sinking Creek Mountain, Southern Appalachians, Virginia: Geology, v. 14, no. 1, p. 11-14.
Southworth, C.S., and Schultz, A.P., 1986, Characteristics of giant rockslides in the Appalachian Valley and Ridge, Virginia, West Virginia, Maryland, and Pennsylvania: United States Geological Survey Open-File Report 86-94, 4 p., 3 oversized sheets. 


\section{LANDSLIDE INFORMATION CENTER}

\section{Don Nichols}

The Landslide Information Center is a major element of the U.S. Geological Survey's Landslide Research Program. The objectives of the Center are to acquire data from landslide research for use in the reduction of hazards and to promote the mitigation of such hazards through engineering design and land-use planning. The Center seeks to (1) provide a centralized source of bibliographic and landslide activities information in a computerized data storage and retrieval system, (2) develop and maintain a file of photographs, press releases, reports, maps, and legislation (ordinances, land-use regulations) on landslides, (3) develop and maintain a mailing list of research and user-oriented people interested in landslide hazard reduction, (4) respond to requests for information and contribute to periodic newsletters, such as that of the National Academy of Sciences' Committee on Ground Failure Hazards Mitigation Research, to inform researchers and users of activities, results, and other items of interest on landslides, and (5) sponsor workshops designed to transfer results of research toward the reduction of landslide hazards.

To date, the Landslide Information Center has (1) acquired more than 3,000 reports and maps on landslides and entered these and an additional 500 references into a computerized bibliographic data management system, (2) compiled a computerized list of over 900 names, addresses, and telephone numbers of landslide researchers and users of landslide information, (3) acquired approximately 850 copies of newspaper clippings, most of which were contributed by Dr. C.F.S. Sharpe, dating as far back as the 1930's, (4) maintained a file of landslide photographs (slides and prints), (5) acquired copies of miscellaneous codes, ordinances, and other legislation dealing with mitigation of landslide hazards, (6) responded to requests within the U.S. Geological Survey for information and bibliographic searches on landslides, (7) sponsored the 3rd International Landslide Field Trip in Appalachia and a 2-day conference on Landslide Mapping and Mitigation in Reston, Virginia, and (8) sponsored a U.S Geological Survey workshop that resulted in the publication of "Goals and Tasks of the Landslide Part of a Ground-Failure Hazards Reduction Program" (U.S. Geological Survey Circular 880).

The Center welcomes inquiries on landslide research and will conduct limited searches of its computerized bibliographic data base. Copies of a three-page list of keywords to guide searches are available on request. Documents in the files may be examined at the Center on the 4th floor at 1711 Illinois Avenue, Golden, Colorado; copies of maps and reports can be obtained at cost through local reproduction firms. Telephone inquiries should be made of Jean M. DeWoody at (303) 236-1675 or of Donald R. Nichols, Chief of the Landslide Information Center, at (303) 236-1599.

The Center solicits copies of reports, maps, photographs, newspaper clippings, legislation, and information on landslide research completed or in progress, and especially on innovative methods of landslide hazard mitigation. Such contributions should be addressed to the Landslide Information Center, U.S. Geological Survey, MS 966, Box 25046, Denver, CO 80225. 
